\title{
Studies toward Soraphen A: an aldol metathesis avenue to the macrocyclic framework
}

\author{
Guillaume Vincent, ${ }^{a}$ Darren J. Mansfield, ${ }^{b}$ Jean-Pierre Vors ${ }^{b}$ and Marco A. Ciufolini*a,c \\ ${ }^{a}$ Laboratoire de Synthèse et méthodologie Organique (LSMO), CNRS UMR 5181, \\ Université Claude Bernard-Lyon I and Ecole Supérieure de Chimie, Physique et Electronique de Lyon, \\ 43, Bld du 11 Novembre 1918, 69622 Villeurbanne Cedex, France \\ ${ }^{b}$ Bayer CropScience SA, 14-20 rue Pierre Baizet,69009 Lyon, France \\ ${ }^{c}$ Department of Chemistry, University of British Columbia, 2036 Main Mall, Vancouver, BC V6T 1Z1, Canada
}

ol060882s 


\section{Table of Contents}

Subject page

Experimental Protocols

Synthesis of Fragment 2

preparation of compound $\mathbf{5}$

preparation of compound $\mathbf{6} \quad 3$

preparation of compound $7 \quad 3$

preparation of compound $\mathbf{8} 4$

preparation of compound 9

preparation of compound 2

determination of $\mathrm{C}-17$ absolute

configuration and enantiomeric excess 5

determination of $\mathrm{C}-11$ / $\mathrm{C}-12$ relative configuration and diastereomeric excess 6

determination of C-11 / C-12 absolute

$\begin{array}{ll}\text { configuration and enantiomeric excess } & 7\end{array}$

$\begin{array}{lr}\text { Synthesis of fragment } 3 & 8\end{array}$

preparation of compound $\mathbf{1 3} \quad 8$

preparation of compound $\mathbf{1 4} \quad 8$

determination of the relative
configuration of $\mathbf{1 4}$

preparation of compound $\mathbf{1 5} \quad 9$

preparation of compounds $\mathbf{1 6}$ and $\mathbf{3 6} 9$

preparation of compound $\mathbf{1 7} \quad 10$

preparation of compound $\mathbf{1 8} 11$

Assembly of the soraphen A framework $\quad 11$

preparation of compound $\mathbf{2 1} 11$

preparation of compound $22 \quad 12$

$\begin{array}{lr}\text { Olefin isomerization during metathesis } & 12\end{array}$

characterization of compound $\mathbf{2 3} \quad 12$

characterization of compound $\mathbf{3 3} \quad 12$

Cross-metathesis avenue to seco-soraphen A 12

preparation of compound $\mathbf{3 7} \quad 12$

preparation of compound $\mathbf{3 8} \quad 13$

Synthesis of compounds $\mathbf{2 6}-\mathbf{2 8} \quad 13$

preparation of intermediates 13

preparation of compound $26 \quad 14$

preparation of compound $27 \quad 15$

preparation of compound $\mathbf{2 8} \quad 15$

Index of hardcopy ${ }^{1} \mathrm{H}$ and ${ }^{13} \mathrm{C}$ NMR spectra $\quad 16$

$\begin{array}{ll}\text { spectra } & 17\end{array}$ 
Experimental protocols : Proton and ${ }^{13} \mathrm{C}$ NMR spectra were obtained from $\mathrm{CDCl}_{3}$ as solvent. Chemical shifts are reported in parts per million (ppm) on the $\delta$ scale and coupling constants, $J$, are in hertz $(\mathrm{Hz})$. Proton NMR spectra were recorded at 300 or $500 \mathrm{MHz}$, as specified, ${ }^{13} \mathrm{C}$ NMR spectra were recorded at 75 or $125 \mathrm{MHz}$, as specified. FT-IR spectra (cm1) were recorded neat. Mass spectra $(\mathrm{m} / \mathrm{z})$ were measured in the chemical ionization $(\mathrm{CI}$, isobutene as the reagent gas), electrospray (ESI), electronic impact (EI) or liquid secondary mass spectroscopy (LSIMS) mode, as specified. All reactions were performed under dry Ar over dried flasks equipped with Teflon ${ }^{\mathrm{TM}}$ stirbars. All flasks were fitted with rubber septa for the introduction of substrates, reagents, and solvents via syringe. Commercial reagents were used without further purification, except THF (freshly distilled from $\mathrm{Na} /$ benzophenone under Ar) and $\mathrm{CH}_{2} \mathrm{Cl}_{2}$ (freshly distilled from $\mathrm{CaH}_{2}$ under $\mathrm{Ar}$ ).

* Synthesis of fragment 2.<smiles>COCC(CCCCC(=O)c1ccccc1)OC</smiles>

Compound 5: Ozone was bubbled to a solution of $5.18 \mathrm{~g}$ of 1phenylcyclohexene 4 (32.8 mmol) in $150 \mathrm{~mL}$ of dichloromethane and 150 $\mathrm{mL}$ of methanol at $-78^{\circ} \mathrm{C}$ until the apparition of a blue color ( 3 hours). Oxygen was then bubbled until the blue color disappeared (20 min), argon was bubbled $20 \mathrm{~min}$ and $12 \mathrm{~mL}$ of dimethyl sulfide $(164 \mathrm{mmol})$ and $312 \mathrm{mg}$ of $p \mathrm{TsOH}(1.6 \mathrm{mmol})$ were then added. The reaction was stirred $12 \mathrm{hrs}$ at $\mathrm{RT}$ and concentrated under vacuum. The crude was then diluted with $200 \mathrm{~mL}$ of $\mathrm{CH}_{2} \mathrm{Cl}_{2}$ and $200 \mathrm{~mL}$ of a saturated aqueous solution of $\mathrm{NaHCO}_{3}$. The organic phase was separated and the aqueous phase was extracted with $200 \mathrm{~mL}$ of $\mathrm{CH}_{2} \mathrm{Cl}_{2}$. The combined extracts were dried with $\mathrm{Na}_{2} \mathrm{SO}_{4}$ and concentrated. Silica gel chromatography of the residue (ethyl acetate/ cyclohexane, 1:9) afforded the desired product 5 as a colorless oil $(6.46 \mathrm{~g}, 83 \%) .{ }^{1} \mathbf{H}$ NMR (300 MHz, CDCl $)$ : 7.97-7.93 (m, 2H), 7.58-7.43 (m, 3H), $4.38(\mathrm{t}, J=5.6 \mathrm{~Hz}, 1 \mathrm{H})$, $3.32(\mathrm{~s}, 6 \mathrm{H}), 2.98(\mathrm{t}, J=7.3 \mathrm{~Hz}, 2 \mathrm{H}), 1.85-1.62(\mathrm{~m}, 4 \mathrm{H}), 1.48-1.41(\mathrm{~m}, 2 \mathrm{H})$.<smiles>COC(CO)CCCCC(O)c1ccccc1</smiles>

Compound 6: To a solution of $5.20 \mathrm{~g}$ of $5(22.1 \mathrm{mmol})$ in $70 \mathrm{~mL}$ of THF at $-30^{\circ} \mathrm{C}$ were added $5 \mathrm{~mL}$ of a $1 \mathrm{M}$ solution of (R)-2-methyl-CBSoxazaborolidine $(5 \mathrm{mmol})$ in THF, then dropwise $22.1 \mathrm{~mL}$ of a $2 \mathrm{M}$ solution of $\mathrm{BH}_{3}$.DMS $(44.1 \mathrm{mmol})$ in $\mathrm{THF}$ at $-30^{\circ} \mathrm{C}$. The reaction mixture was then stirred $2 \mathrm{hrs}$ at $-10^{\circ} \mathrm{C}$ and quenched with $10 \mathrm{~mL}$ of methanol. The reaction mixture was stirred $15 \mathrm{~min}$ at $\mathrm{RT}$ and a saturated aqueous solution of $\mathrm{NH}_{4} \mathrm{Cl}(80 \mathrm{~mL})$ was added. The organic phase was separated and the aqueous phase was extracted with $100 \mathrm{~mL}$ of EtOAc. The combined extracts were dried with $\mathrm{Na}_{2} \mathrm{SO}_{4}$ and concentrated. Silica gel chromatography of the residue (ethyl acetate/ cyclohexane, 2/8) afforded the desired product as a colorless oil $(4.90 \mathrm{~g}, 93 \%)$ with a diastereomeric excess of $70 \%$ determined by the Mosher's method (see compounds a and b). ${ }^{\mathbf{1}} \mathbf{H}$ NMR (300 MHz, CDCl $\left._{3}\right): 7.35-7.28(\mathrm{~m}, 5 \mathrm{H}), 4.67(\mathrm{~m}, 1 \mathrm{H}), 4.33(\mathrm{t}, J=5.6 \mathrm{~Hz}, 1 \mathrm{H}), 3.29(\mathrm{~s}, 6 \mathrm{H}), 1.81-1.62$ (m, 2H), 1.61-1.54 (m, 2H), 1.53-1.33 (m, 4H). ${ }^{13} \mathbf{C}$ NMR (75 MHz, CDCl 3$): 145.4,128.7$, 127.8, 126.3, 104.7, 74.7, 52.9, 39.4, 32.7, 26.0, 24.8. IR ( $\left.\mathbf{c m}^{-1}\right): 3420,2937,1453,1126$, 1050, 701. HRMS (EI): calculated 237.1491, found $237.1493\left(\mathbf{M}^{+}-\mathrm{H}\right) .[\alpha]_{\mathbf{D}}{ }^{22}-22.6(c 0.19$, $\mathrm{CH}_{2} \mathrm{Cl}_{2}$ ).

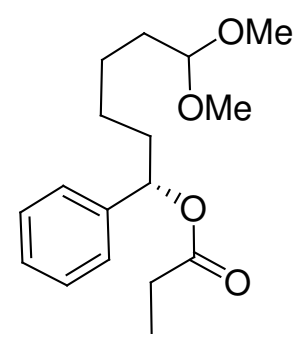

Compound 7: To a solution of $4.80 \mathrm{~g}$ of alcohol 6 (20.2 mmol) and 101 $\mathrm{mg}$ of DMAP $(1.01 \mathrm{mmol})$ in $60 \mathrm{~mL}$ of $\mathrm{CH}_{2} \mathrm{Cl}_{2}$ at $0^{\circ} \mathrm{C}$ were added $8.4 \mathrm{~mL}$ of $\mathrm{Et}_{3} \mathrm{~N}$ (61 mmol) and $3.6 \mathrm{~mL}$ of propionyl chloride $(41 \mathrm{mmol})$. The reaction was stirred $12 \mathrm{hrs}$ at $\mathrm{RT}$ and a saturated aqueous solution of $\mathrm{NaHCO}_{3}(40 \mathrm{~mL})$ was added. The organic phase was separated and the 
aqueous phase was extracted with $40 \mathrm{~mL}$ of $\mathrm{CH}_{2} \mathrm{Cl}_{2}$. The combined extracts were dried with $\mathrm{Na}_{2} \mathrm{SO}_{4}$ and concentrated. Silica gel chromatography of the residue (ethyl acetate/ cyclohexane, 1:9) afforded the desired product as a colorless oil $(5,32 \mathrm{~g}, 89 \%)$. ${ }^{\mathbf{1}} \mathbf{H}$ NMR (300 MHz, $\left.\mathbf{C D C l}_{3}\right):$ 7.33-7.29 (m, 5H), $5.73(\mathrm{dd}, J=7.5,6.4 \mathrm{~Hz}, 1 \mathrm{H}), 4.31(\mathrm{t}, J=5.6 \mathrm{~Hz}, 1 \mathrm{H})$, $3.29(\mathrm{~s}, 6 \mathrm{H}), 2.34(\mathrm{dq}, J=7.5 \mathrm{~Hz}, 3.0 \mathrm{~Hz}, 2 \mathrm{H}), 1.95-1.87(\mathrm{~m}, 1 \mathrm{H}), 1.86-1.78(\mathrm{~m}, 1 \mathrm{H}), 1.65-$ $1.55(\mathrm{~m}, 2 \mathrm{H}), 1.53-1.24(\mathrm{~m}, 4 \mathrm{H}), 1.12(\mathrm{t}, J=7.5 \mathrm{~Hz}, 3 \mathrm{H}) .{ }^{13} \mathbf{C}$ NMR (75 MHz, CDCl $\left.\mathbf{3}\right)$ : 174.2, 141.4, 129.0, 128.3, 127.0, 104.8, 76.2, 53.1, 36.8, 32.8, 28.3, 25.9, 24.8, 9.5. IR (cm ${ }^{-}$ 1): 3418, 2938, 2858, 1737, 1454, 1385, 1189, 1127, 1051, 701. MS (ESI): $317.1\left(\mathrm{M}+\mathrm{Na}^{+}\right)$. HRMS (EI): calculated 293.1753, found $293.1751\left(\mathrm{M}^{+}-\mathrm{H}\right) .[\alpha]_{\mathrm{D}}{ }^{22}-48.0\left(c 1.12, \mathrm{CH}_{2} \mathrm{Cl}_{2}\right)$.

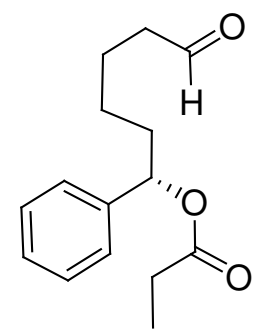

Compound 8: A solution of $2.10 \mathrm{~g}$ of acetal $7(7.15 \mathrm{mmol})$ in $15 \mathrm{~mL}$ of $\mathrm{CHCl}_{3}, 4 \mathrm{~mL}$ of TFA and $4 \mathrm{~mL}$ of water was stirred $3 \mathrm{hrs}$ at RT. The mixture was then diluted with $20 \mathrm{~mL}$ of water and $20 \mathrm{~mL}$ of $\mathrm{CH}_{2} \mathrm{Cl}_{2}$. The organic phase was separated and the aqueous phase was extracted with $30 \mathrm{~mL}$ of $\mathrm{CH}_{2} \mathrm{Cl}_{2}$. The organic phase was then washed with $30 \mathrm{~mL}$ of a saturated aqueous solution of $\mathrm{NaHCO}_{3}$. The combined extracts were dried with $\mathrm{Na}_{2} \mathrm{SO}_{4}$ and concentrated. The desired product was obtained as a colorless oil (1.65 g, 91\%) and engaged immediately in the next step. ${ }^{1} \mathbf{H}$ NMR (300 MHz, $\left.\mathbf{C D C l}_{3}\right): 9.74$ (s, 1H), $7.36-7.27(\mathrm{~m}, 5 \mathrm{H}), 5.74(\mathrm{dd}, J=7.5,6.0 \mathrm{~Hz}, 1 \mathrm{H}), 2.43-2.31(\mathrm{~m}, 4 \mathrm{H}), 1.97-1.87(\mathrm{~m}, 1 \mathrm{H})$, 1.86-1.75 (m, 1H), 1.70-1.59 (m, 2H), 1.43-1.24 (m, 2H), $1.13(\mathrm{t}, J=7.5 \mathrm{~Hz}, 3 \mathrm{H}) .{ }^{13} \mathrm{C} \mathrm{NMR}$ (75 MHz, $\mathbf{C D C l}_{3}$ ): 202.2, 173.6, 140.5, 128.3, 127.7, 126.3, 75.4, 43.5, 36.0, 27.7, 24.9, 21.6, 8.9. IR $\left(\mathbf{c m}^{-1}\right): 2914,2847,1704,1455,1277,1185,1079 .[\alpha]_{\mathbf{D}}{ }^{22}-54.6\left(c 1.2, \mathrm{CH}_{2} \mathrm{Cl}_{2}\right)$.

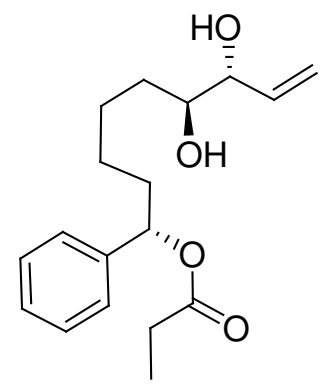

Compound 9: To a solution of $3.80 \mathrm{~g}$ of allyl (cyclohexanol) dimethylsilane $(19.2 \mathrm{mmol})$ in $50 \mathrm{~mL}$ of $\mathrm{THF}$ at $-78^{\circ} \mathrm{C}$ were added 19.2 $\mathrm{mL}$ of a $1 \mathrm{M}$ solution of potassium tert-butoxide $(19.2 \mathrm{mmol})$ in THF and $7.8 \mathrm{~mL}$ of a $2,4 \mathrm{M}$ solution of butyllithium $(19.2 \mathrm{mmol})$ in hexane. The reaction was stirred $1 \mathrm{hr}$ at $-40^{\circ} \mathrm{C}$ and cooled to $-78^{\circ} \mathrm{C}, 7.20 \mathrm{~g}$ of (+)-DIP chloride $(22.4 \mathrm{mmol})$ were then added. The reaction was stirred $1 \mathrm{hr}$ at $-78^{\circ} \mathrm{C}$ and $2.9 \mathrm{~mL}$ boron trifluoride, etherate $(23 \mathrm{mmol})$ were added. After $5 \mathrm{~min}, 1.65 \mathrm{~g}$ of aldehyde $8(6.60 \mathrm{mmol})$ in $5 \mathrm{~mL}$ of THF were added and the reaction was stirred $8 \mathrm{hrs}$ at $-78^{\circ} \mathrm{C}$ and then let warmed overnight to RT. At his point 30 $\mathrm{mL}$ of methanol, $15 \mathrm{~mL}$ of $30 \%$ hydrogen peroxide in water, $12 \mathrm{~g}$ of $\mathrm{KHCO}_{3}$ and $6 \mathrm{~g}$ of potassium fluoride were added. The reaction was stirred $20 \mathrm{hrs}$ at RT and $50 \mathrm{~mL}$ of a saturated aqueous solution of $\mathrm{Na}_{2} \mathrm{~S}_{2} \mathrm{O}_{3}$ was added very carefully at $0^{\circ} \mathrm{C}$. The mixture was diluted with $100 \mathrm{~mL}$ of AcOEt and $100 \mathrm{~mL}$ of a saturated aqueous solution of $\mathrm{NaHCO}_{3}$. The organic phase was separated and the aqueous phase was extracted with $150 \mathrm{~mL}$ of AcOEt. The combined extracts were dried with $\mathrm{Na}_{2} \mathrm{SO}_{4}$ and concentrated. Silica gel chromatography of the residue (ethyl acetate/ cyclohexane, 1:9 to 3:7) afforded the desired product as a colorless oil $(1.02 \mathrm{~g}, 51 \%)$ with a diastereomeric excess of $70 \%$ determined by the Mosher's method (see compounds $\mathbf{d}$ and $\mathbf{f}$ ). Separation was effected at the next step. ${ }^{1} \mathbf{H}$ NMR (300 MHz, $\left.\mathbf{C D C l}_{3}\right)$ : 7.36-7.26 (m, 5H), $5.87(\mathrm{ddd}, J=17.1,10.4,6.4 \mathrm{~Hz}, 1 \mathrm{H}), 5.73(\mathrm{dd}, J=7.6$, $6.1 \mathrm{~Hz}, 1 \mathrm{H}), 5.20-5.32(\mathrm{~m}, 2 \mathrm{H}), 4.04(\mathrm{dd}, J=6.4,3.6 \mathrm{~Hz}, 1 \mathrm{H}), 3.65-3.59(\mathrm{~m}, 1 \mathrm{H}), 2.34(\mathrm{qd}, J$ $=7.5,2.8 \mathrm{~Hz}, 2 \mathrm{H}), 1.97-1.82(\mathrm{~m}, 1 \mathrm{H}), 1.81-1.70(\mathrm{~m}, 1 \mathrm{H}), 1.56-1.46(\mathrm{~m}, 1 \mathrm{H}), 1.42-1.22(\mathrm{~m}$, $5 \mathrm{H}), 1.12(\mathrm{t}, J=7.5 \mathrm{~Hz}, 3 \mathrm{H}) .{ }^{13} \mathbf{C}$ NMR (75 MHz, $\left.\mathbf{C D C l}_{3}\right): 174.4,141.2,136.5,128.8,128.2$, 126.8, 117.9, 76.4, 76.1, 74.3, 36.7, 32.2, 28.2, 25.9, 25.8, 9.5. IR $\left(\mathbf{c m}^{-1}\right): 3381,2937,2859$, 1731, 1455, 1185, 1080, 997, 699. MS (ESI): $329.1\left(\mathrm{M}+\mathrm{Na}^{+}\right)$. HRMS (CI): calculated 307.1909, found $307.1908\left(\mathrm{M}+\mathrm{H}^{+}\right)$. [ $\left.\alpha\right]_{\mathbf{D}}{ }^{22}-45.1\left(c 0.64, \mathrm{CH}_{2} \mathrm{Cl}_{2}\right)$. 


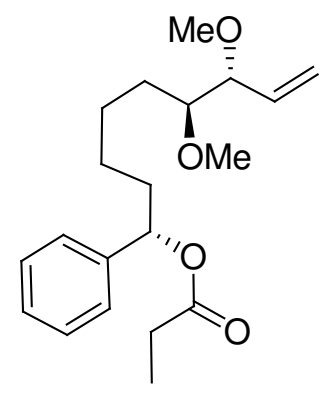

Compound 2: A solution of $200 \mathrm{mg}$ of diol $9(0.65 \mathrm{mmol}), 979 \mathrm{mg}$ of proton sponge ${ }^{\circledR}(4.57 \mathrm{mmol})$ and $677 \mathrm{mg}$ of trimethyloxonium tetrafluoroborate $(4.57 \mathrm{mmol})$ in $5 \mathrm{~mL}$ of $\mathrm{CH}_{2} \mathrm{Cl}_{2}$ was stirred $12 \mathrm{hrs}$ at $\mathrm{RT}$; $10 \mathrm{~mL}$ of a $1 \mathrm{~N}$ aqueous solution of hydrochloric acid and $5 \mathrm{~mL}$ of $\mathrm{CH}_{2} \mathrm{Cl}_{2}$ were added. The organic phase was separated and the aqueous phase was extracted with $10 \mathrm{~mL}$ of $\mathrm{CH}_{2} \mathrm{Cl}_{2}$. The combined extracts were dried with $\mathrm{Na}_{2} \mathrm{SO}_{4}$ concentrated. Silica gel chromatography of the residue (ethyl acetate/ cyclohexane, 1:9) afforded the dimethylated product 2 as a red oil (110 mg, 50\%) with a diastereomeric excess of $90 \%$ and a mixture of the two monomethylated products as a red oil $(65 \mathrm{mg}, 31 \%)$.

The monomethylated products could be methylated using the same procedure with $215 \mathrm{mg}$ of proton sponge $(1 \mathrm{mmol}), 149 \mathrm{mg}$ of trimethyloxonium tetrafluoroborate $(1 \mathrm{mmol})$ in $3 \mathrm{~mL}$ of $\mathrm{CH}_{2} \mathrm{Cl}_{2}$. The pure dimethylated product 2 was obtained as a red oil $(40 \mathrm{mg}, 60 \%)$ with a diastereomeric excess of $90 \%$. The overall yield of $\mathbf{2}$ is $70 \%(90 \% \mathrm{de}) .{ }^{\mathbf{1}} \mathbf{H} \mathbf{~ N M R}(\mathbf{3 0 0} \mathbf{~ M H z}$, $\left.\mathbf{C D C l}_{3}\right)$ : 7.35-7.23 (m, 5H), 5.80-5.68 (m, 2H), 5.32-5.21 (m, 2H), 3.55 (ddd, $J=7.6,3.8$, $0.8 \mathrm{~Hz}, 1 \mathrm{H}), 3.39(\mathrm{~s}, 3 \mathrm{H}), 3.28(\mathrm{~s}, 3 \mathrm{H}), 3.18-3.12(\mathrm{~m}, 1 \mathrm{H}), 2.33(\mathrm{qd}, J=7.6,2.8 \mathrm{~Hz}, 2 \mathrm{H}), 1.99-$ $1.85(\mathrm{~m}, 1 \mathrm{H}), 1.82-1.70(\mathrm{~m}, 1 \mathrm{H}), 1.46-1.25(\mathrm{~m}, 6 \mathrm{H}), 1.12(\mathrm{t}, J=7.6 \mathrm{~Hz}, 3 \mathrm{H}) .{ }^{13} \mathbf{C}$ NMR $(75$ MHz, $\left.\mathbf{C D C l}_{3}\right):$ 174.1, 141.3, 135.6, 128.8, 128.2, 127.0, 119.2, 84.7, 83.6, 76.2, 58.9, 57.1, $36.7,30.5,28.2,26.0,9.5$. IR $\left(\mathbf{c m}^{-1}\right): 2937,2862,1735,1455,1183,1002,997,699,637 . \mathbf{M S}$ (ESI): $357.1\left(\mathrm{M}+\mathrm{Na}^{+}\right)$. HRMS (CI): calculated 335.2222, found $335.2222\left(\mathrm{M}+\mathrm{H}^{+}\right)$. $[\alpha]_{\mathbf{D}}{ }^{22}-56.2\left(c \quad 0.60, \mathrm{CH}_{2} \mathrm{Cl}_{2}\right)$.

* Determination of the absolute configuration and enantioselectivity at C-17

According to the method of Mosher as in Dale, J. A.; Mosher, H. S. A. J. Am. Chem. Soc. 1973, 95, 512 .<smiles>COC(CCCCC(OC)c1ccccc1)C(=O)OC(C)(OC)c1ccccc1</smiles>

Compound a: A solution of $21 \mathrm{mg}$ of alcool 6 (0.088 mmol), $62 \mathrm{mg}$ of (R)-(+)-alpha-methoxy-alpha-(trifluoromethyl)-phenylacetic acid $(0.264 \mathrm{mmol}), 55 \mathrm{mg}$ of DCC $(0.264 \mathrm{mmol})$ and $6 \mathrm{mg}$ of DMAP (0.044 mmol) in $0.8 \mathrm{~mL}$ of $\mathrm{CH}_{2} \mathrm{Cl}_{2}$ was stirred $24 \mathrm{hrs}$ at $\mathrm{RT}$. The crude was then diluted with $5 \mathrm{~mL}$ of $\mathrm{CH}_{2} \mathrm{Cl}_{2}$ and $5 \mathrm{~mL}$ of a saturated aqueous solution of $\mathrm{NaHCO}_{3}$. The organic phase was separated and the aqueous phase was extracted with $5 \mathrm{~mL}$ of $\mathrm{CH}_{2} \mathrm{Cl}_{2}$. The combined extracts were dried with $\mathrm{Na}_{2} \mathrm{SO}_{4}$ concentrated. Silica gel chromatography of the residue (ethyl acetate/ cyclohexane, 1:9) afforded the desired product as a colorless oil (32 $\mathrm{mg}, 83 \%)$. ${ }^{1} \mathbf{H}$ NMR (300 MHz, $\left.\mathbf{C D C l}_{3}\right): 7.38-7.19(\mathrm{~m}, 10 \mathrm{H}), 5.88(\mathrm{dd}, J=7.9,6.0 \mathrm{~Hz}, 1 \mathrm{H}), 4.31(\mathrm{t}, J=5.6 \mathrm{~Hz}, 1 \mathrm{H})$, 3.53 (s, 3H), 3.29 (s, 6H), 2.05-1.95 (m, 1H), 1.88-1.75 (m, 1H), 1.62-1.52 (m, 2H), 1.43-1.29 $(\mathrm{m}, 4 \mathrm{H}) .{ }^{13} \mathbf{C}$ NMR (75 MHz, $\left.\mathbf{C D C l}_{3}\right):$ 166.0, 139.3, 129.6, 128.6, 128.5, 128.4, 127.5, 126.9, 104.5, 79.0, 55.7, 52.9, 52.8, 36.1, 32.4, 25.5, 24.3. ${ }^{19}$ F NMR (300 MHz, CDCl $\mathbf{~ M}_{3}$ ): -71.71 (s, 4F), -71.96 (s, 96F). Diastereomeric excess: $92 \%$. MS (ESI): $477.0\left(\mathrm{M}+\mathrm{Na}^{+}\right) \cdot[\alpha]_{\mathrm{D}}{ }^{22}-5.5(c$ $1.30, \mathrm{CH}_{2} \mathrm{Cl}_{2}$ ).<smiles>COC1CCCC[C@H](OC(=O)C(c2ccccc2)(c2ccccc2)C(F)(F)F)c2ccccc21</smiles>

Compound b: This compound was prepared with the same procedure as compound a with $21 \mathrm{mg}$ of alcohol 6 (0.088 mmol), $62 \mathrm{mg}$ of (S)-()-alpha-methoxy-alpha-(trifluoromethyl)-phenylacetic acid $\quad(0.26$ $\mathrm{mmol}), 54.5 \mathrm{mg}$ of DCC (0.26 mmol) and $5 \mathrm{mg}$ of DMAP $(0.04 \mathrm{mmol})$ in $1 \mathrm{~mL}$ of $\mathrm{CH}_{2} \mathrm{Cl}_{2}$. The product was obtained as a colourless oil (28.5 mg, 71\%). ${ }^{1} \mathbf{H N M R}\left(\mathbf{3 0 0} \mathbf{M H z}, \mathbf{C D C l}_{3}\right):$ 7.45-7.28 (m, 10H), 5.95 (dd, 
$J=8.2,5.7, \mathrm{~Hz}, 1 \mathrm{H}), 4.28(\mathrm{t}, J=5.7 \mathrm{~Hz}, 1 \mathrm{H}), 3.44(\mathrm{~s}, 3 \mathrm{H}), 3.28(\mathrm{~s}, 6 \mathrm{H}), 2.02-1.91(\mathrm{~m}, 1 \mathrm{H})$, 1.84-1.72 (m, 1H), 1.55-1.46 (m, 2H), 1.39-1.11 (m, 4H). ${ }^{13}$ C NMR (75 MHz, CDCl $)$ : 166.0, 139.1, 132.4, 129.5, 128.6, 128.5, 128.4, 128.2, 127.3, 126.9, 104.3, 78.5, 55.4, 52.7, 52.5, 35.7, 32.2, 25.0, 24.0. ${ }^{19} \mathbf{F}$ NMR (300 MHz, $\left.\mathbf{C D C l}_{3}\right)$ : -71.67 (s, 4F), -71.71 (s, 96F). Diastereomeric excess: $92 \%$ MS (ESI): $477.0\left(\mathrm{M}+\mathrm{Na}^{+}\right)$. [ $\left.\alpha\right]_{\mathbf{D}}{ }^{22}-73.4\left(c 1.09, \mathrm{CH}_{2} \mathrm{Cl}_{2}\right)$.

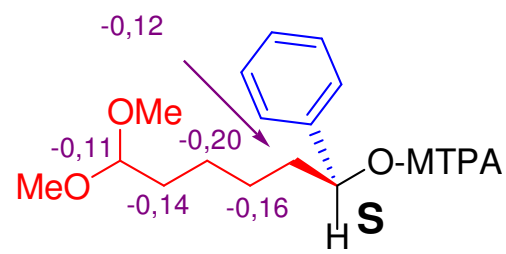

$\Delta \delta H^{S, R}=\delta^{S}-\delta^{R}<0$

The absolute configuration at $\mathrm{C} 17$ is $(S)$ and the enantiomeric excess is $92 \%$.

* Determination of the relative configuration between $\mathrm{C} 11$ and $\mathrm{C} 12$.<smiles>C=CC1OC(C)(C)OC1CCCCC(OC(=O)CC)c1ccccc1</smiles>

Compound c: A solution of $20 \mathrm{mg}$ of diol $9(0.065 \mathrm{mmol}), 12 \mu \mathrm{L}$ of 2,2dimethoxypropane $(0.098 \mathrm{mmol})$ and pyridiniumparatoluensulfonate. $(0.006 \mathrm{mmol})$ in $1 \mathrm{~mL}$ of $\mathrm{CH}_{2} \mathrm{Cl}_{2}$ was stirred $12 \mathrm{hrs}$ at RT. The crude was then diluted with $5 \mathrm{~mL}$ of $\mathrm{CH}_{2} \mathrm{Cl}_{2}$ and $5 \mathrm{~mL}$ of a saturated aqueous solution of $\mathrm{NaHCO}_{3}$. The organic phase was separated and the aqueous phase was extracted with $5 \mathrm{~mL}$ of $\mathrm{CH}_{2} \mathrm{Cl}_{2}$. The combined extracts were dried with $\mathrm{Na}_{2} \mathrm{SO}_{4}$ concentrated. Silica gel chromatography of the residue (ethyl acetate/ cyclohexane, 1:9) afforded the desired product as a colorless oil (22.5 mg, 95\%). ${ }^{1} \mathbf{H N M R}\left(\mathbf{3 0 0} \mathbf{~ M H z}, \mathbf{C D C l}_{\mathbf{3}}\right)$ : 7.36-7.24 $(\mathrm{m}, 5 \mathrm{H}), 5.84-5.71(\mathrm{~m}, 2 \mathrm{H}), 5.31-5.18(\mathrm{~m}, 2 \mathrm{H}), 4.45(\mathrm{t}, J=7.2 \mathrm{~Hz}, 1 \mathrm{H}), 4.13-4.05(\mathrm{~m}, 1 \mathrm{H})$, $2.34(\mathrm{qd}, J=7.5,2.6 \mathrm{~Hz}, 2 \mathrm{H}), 1.96-1.83(\mathrm{~m}, 1 \mathrm{H}), 1.82-1.68(\mathrm{~m}, 1 \mathrm{H}), 1.55-1.21(\mathrm{~m}, 6 \mathrm{H}), 1.47$ (s, 3H), 1.35 (s, 3H), $1.12(\mathrm{t}, J=7.5 \mathrm{~Hz}, 3 \mathrm{H}) .{ }^{13} \mathbf{C}$ NMR (75 MHz, CDCl $)$ : 174.2, 141.3, $134.9,128.8,128.2,126.8,118.6,108.9,80.9,80.2,76.1,36.7,30.7,28.7,28.2,26.4,26.0$, 25.9, 9.5. IR $\left(\mathbf{c m}^{-1}\right): 2915,2848,1736,, 1462,1367,1259,, 1081,1016,796,638$. HRMS (EI): calculated 346.2144, found 346.2141 $\left(\mathrm{M}^{+}\right)$. [ $\left.\alpha\right]_{\mathbf{D}}{ }^{22}-47.1\left(c 0.37, \mathrm{CH}_{2} \mathrm{Cl}_{2}\right)$.

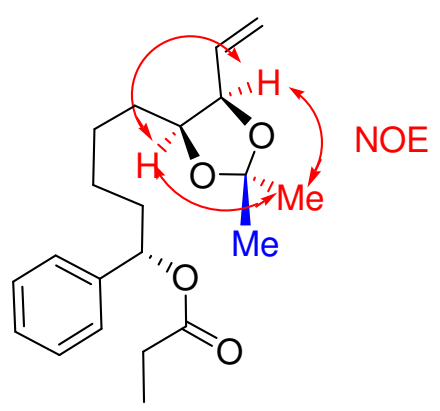

NOE demonstrates the anti relationship between substituents at $\mathrm{C11}$ and $\mathrm{C12}$. 
* Determination of absolute configurations at $\mathrm{C} 11$ and $\mathrm{C} 12$ and stereoselectivity.

According to the method of Mosher for 1,2 anti diol as in Ichikawa, A.; Takahashi, H.; Ooi, T.; Kuzumi, T. Biosci. Biotech. Biochem. 1997, 61, 881. .<smiles>C=C[C@H](OC(=O)C(OC)(c1ccccc1)C(F)(F)F)C(CCCC[C@@H](OC(=O)CC)c1ccccc1)OC(=O)C(c1ccccc1)(c1ccccc1)C(F)(F)F</smiles>

Compound d: This compound was prepared with the same procedure as compound a with $14 \mathrm{mg}$ of diol $9(0.045 \mathrm{mmol})$, $64.2 \mathrm{mg}$ of (R)-(+)-alpha-methoxy-alpha-(trifluoromethyl)phenylacetic acid $(0.27 \mathrm{mmol}), 55.7 \mathrm{mg}$ of DCC $(0.27 \mathrm{mmol})$ and $6 \mathrm{mg}$ of DMAP $(0.044 \mathrm{mmol})$ in $1 \mathrm{~mL}$ of $\mathrm{CH}_{2} \mathrm{Cl}_{2}$. The product was obtained as a colourless oil $(25 \mathrm{mg}, 75 \%)$. ${ }^{1}$ HNMR (300 MHz, CDCl 3 ): 7.48-7.27 (m, 15H), 5.80 (ddd, $J=17.0,10.0,6.4 \mathrm{~Hz}, 0.15 \mathrm{H}), 5.74-5.52(\mathrm{~m}, 2.85 \mathrm{H}), 5.46(\mathrm{~d}$, $J=17.0 \mathrm{~Hz}, 0.15 \mathrm{H}), 5.40(\mathrm{~d}, J=10.0 \mathrm{~Hz}, 0.15 \mathrm{H}), 5.32-5.21$ $(\mathrm{m}, 2.70 \mathrm{H}), 3.48(\mathrm{~s}, 0.5 \mathrm{H}), 3.45(\mathrm{~s}, 2.5 \mathrm{H}), 3.42-3.39(\mathrm{br}, 3 \mathrm{H})$, $2.34(\mathrm{qd}, J=7.5,2.6 \mathrm{~Hz}, 2 \mathrm{H}), 1.91-1.78(\mathrm{~m}, 1 \mathrm{H}), 1.77-1.66(\mathrm{~m}, 1 \mathrm{H}), 1.45-1.15(\mathrm{~m}, 6 \mathrm{H}), 1.13$ $(\mathrm{t}, J=7.5 \mathrm{~Hz}, 3 \mathrm{H}) .{ }^{13} \mathbf{C}$ NMR (75 MHz, $\left.\mathbf{C D C l}_{3}\right): 174.1,166.5,165.8,146.5,132.4,132.2$, $130.2,130.0,128.9,128.8,128.3,127.8,127.6,126.8,122.1,85.2,77.2,76.6,75.9,55.8$, 36.5, 29.8, 29.5, 28.2, 25.5, 9.5. ${ }^{19}$ F NMR (300 MHz, $\left.\mathbf{C D C l}_{3}\right)$ : -71.71 (s, 15F), -71.86 (s, 85F), -72.04 (s, 15F),-72.06 (s, 85F). Diasteromeric excess: 70\% MS (ESI): $761.1\left(\mathrm{M}+\mathrm{Na}^{+}\right)$. $[\alpha]_{\mathrm{D}}^{22}=+10.4\left(\mathrm{c}=0.64, \mathrm{CH}_{2} \mathrm{Cl}_{2}\right)$.<smiles>C=C[C@H](OC(=O)C(OC)(c1ccccc1)c1ccccc1)C(CCCC[C@H](OC(=O)CC)c1ccccc1)OC(=O)C(OC)(OC)c1ccccc1</smiles>

Compound e: This compound was prepared with the same procedure as compound a with $12.2 \mathrm{mg}$ of diol 9 (0.04 mmol), $56 \mathrm{mg}$ of (S)-(-)-alpha-methoxy-alpha-(trifluoromethyl)phenylacetic acid $(0.24 \mathrm{mmol}), 49 \mathrm{mg}$ of DCC $(0.24 \mathrm{mmol})$ and $2.5 \mathrm{mg}$ of DMAP $(0.02 \mathrm{mmol})$ in $1 \mathrm{~mL}$ of $\mathrm{CH}_{2} \mathrm{Cl}_{2}$. The product was obtained as a colorless oil $(22.4 \mathrm{mg}, 76 \%)$. ${ }^{1}$ HNMR (300 MHz, CDCl $)$ ): 7.55-7.25 (m, 15H), 5.80 (ddd, $J=17.7,10.3,7.5 \mathrm{~Hz}, 1 \mathrm{H}), 5.67(\mathrm{dd}, J=7.2,6.4 \mathrm{~Hz}, 1 \mathrm{H})$, $5.61-5.57(\mathrm{~m}, 1 \mathrm{H}), 5.45(\mathrm{~d}, J=17.7 \mathrm{~Hz}, 1 \mathrm{H}), 5.40(\mathrm{~d}, J=10.3$ $\mathrm{Hz}, 1 \mathrm{H}), 5.35-5.22(\mathrm{~m}, 1 \mathrm{H}), 3.48(\mathrm{~s}, 2.55 \mathrm{H}), 3.46(\mathrm{~s}, 0.45 \mathrm{H})$, $3.41(\mathrm{~s}, 3 \mathrm{H}), 2.35(\mathrm{qd}, J=7.5,3.0 \mathrm{~Hz}, 2 \mathrm{H}), 1.84-1.26(\mathrm{~m}, 8 \mathrm{H}), 1.13(\mathrm{t}, J=7.5 \mathrm{~Hz}, 3 \mathrm{H}) .{ }^{13} \mathbf{C}$ NMR (75 MHz, $\left.\mathbf{C D C l}_{3}\right)$ : 173.8, 169.9, 165,6, 140.8, 138.8, 131.9, 131.8, 130.1, 129.6, 128.5, 128.4, 128.3, 127.8, 127.3 127.2, 126.4, 122.6, 77.1, 75.8, 75.5, 55.4, 36.0, 29.4, 27.8, 25.0, 24.6, 9.1. ${ }^{19}$ F NMR (300 MHz, $\left.\mathbf{C D C l}_{3}\right)$ : $-71.60(85 \mathrm{~F}),-71.77(15 \mathrm{~F}),-71.93(85 \mathrm{~F})$, $71.96(15 \mathrm{~F})$. Diastereomeric excess: $70 \%$ MS (ESI): $761.1\left(\mathrm{M}+\mathrm{Na}^{+}\right) .[\alpha]_{\mathbf{D}}{ }^{22}-59.3(c \quad 0.91$, $\mathrm{CH}_{2} \mathrm{Cl}_{2}$ ).

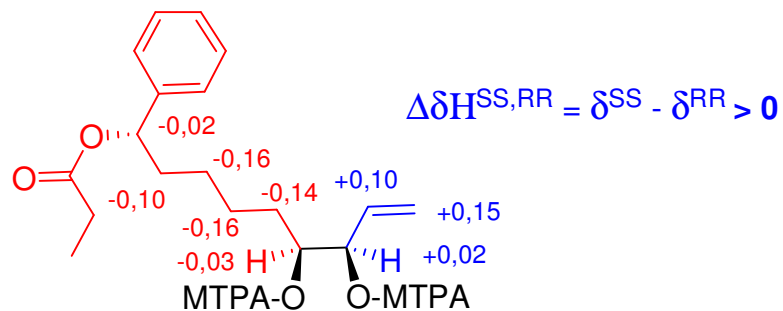

$\Delta \delta \mathrm{H}^{S S, R R}=\delta^{S S}-\delta^{R R}<0$

The absolute config. at $\mathrm{C} 11$ and $\mathrm{C} 12$ are $(S)$ and $(R)$ and the enantiomeric excess is $70 \%$. 
* Synthesis of fragment $\mathbf{3}$

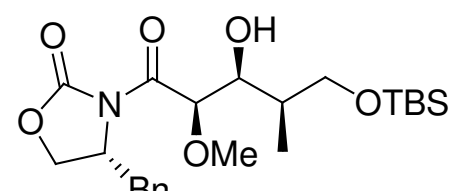

Compound 13: To a solution of $7.39 \mathrm{~g}$ of imide $12(29.7 \mathrm{mmol})$ in $80 \mathrm{~mL}$ of $\mathrm{CH}_{2} \mathrm{Cl}_{2}$ at $-78^{\circ} \mathrm{C}$ were added $29 \mathrm{~mL}$ of a $1 \mathrm{M}$ solution of dibutylboron triflate $(29.0 \mathrm{mmol})$ in $\mathrm{CH}_{2} \mathrm{Cl}_{2}$ and $8.1 \mathrm{~mL}$ of $\mathrm{Et}_{3} \mathrm{~N}(58.0 \mathrm{mmol})$. The mixture was stirred $30 \mathrm{~min}$ at $0^{\circ} \mathrm{C}$ then cooled to $-78^{\circ} \mathrm{C}$. A solution of $9.10 \mathrm{~g}$ of aldehyde $19(44.5 \mathrm{mmol})$ in $10 \mathrm{~mL}$ of $\mathrm{CH}_{2} \mathrm{Cl}_{2}$ was then added and the reaction was stirred $4 \mathrm{hrs}$ at $0^{\circ} \mathrm{C}$. The reaction mixture was then hydrolysed with $50 \mathrm{~mL}$ of a 2:1 mixture of methanol and phosphate buffer $\mathrm{pH} 7$ and then 50 $\mathrm{mL}$ of a 2:1 mixture of methanol and $30 \%$ hydrogen peroxide at $0^{\circ} \mathrm{C}$. After stirring $1 \mathrm{hr}$ at $0^{\circ} \mathrm{C}$, the mixture was concentrated. The crude was then diluted with $100 \mathrm{~mL}$ of $\mathrm{CH}_{2} \mathrm{Cl}_{2}$ and $100 \mathrm{~mL}$ of a saturated aqueous solution of $\mathrm{NaHCO}_{3}$. The organic phase was separated and the aqueous phase was extracted with $80 \mathrm{~mL}$ of $\mathrm{CH}_{2} \mathrm{Cl}_{2}$. The combined extracts were dried with $\mathrm{Na}_{2} \mathrm{SO}_{4}$ and concentrated. Silica gel chromatography of the residue (ethyl acetate/cyclohexane, 3:7) afforded a $3: 1$ mixture of the desired product $\mathbf{1 3}$ and imide $\mathbf{1 2}$ as a yellow oil $(13.5 \mathrm{~g})$. This mixture was used in the next step. A purification of $50 \mathrm{mg}$ of this mixture on a preparative TLC (ethyl acetate/cyclohexane, 3:7) afforded pure 13. ${ }^{\mathbf{1}} \mathbf{H}$ NMR (300 MHz, CDCl $)$ : 7.36-7.21 (m, 5H), $5.10(\mathrm{~d}, J=2.7 \mathrm{~Hz}, 1 \mathrm{H}), 4.74-4.66(\mathrm{~m}, 1 \mathrm{H})$, 4.22-4.12 (m, 2H), 3.89-3.83 (m, 1H), $3.71(\mathrm{dd}, J=9.8,6.9 \mathrm{~Hz}, 1 \mathrm{H}), 3.50(\mathrm{dd}, J=9.8,5.6$ $\mathrm{Hz}, 1 \mathrm{H}), 3.47$ (s, 3H), $3.38(\mathrm{dd}, J=13.3,3.2 \mathrm{~Hz}, 1 \mathrm{H}), 2.85(\mathrm{dd}, J=13.3,9.6 \mathrm{~Hz}, 1 \mathrm{H}), 2.68(\mathrm{~d}$, $J=8.6 \mathrm{~Hz}, 1 \mathrm{H}), 2.03-1.95(\mathrm{~m}, 1 \mathrm{H}), 0.99(\mathrm{~d}, J=6.8 \mathrm{~Hz}, 3 \mathrm{H}), 0.89(\mathrm{~s}, 9 \mathrm{H}), 0.06(\mathrm{~s}, 6 \mathrm{H}) .{ }^{13} \mathbf{C}$ NMR (75 MHz, $\left.\mathbf{C D C l}_{3}\right)$ : 171.0, 153.2, 135.1, 129.4, 129.0, 127.4, 81.0, 73.6, 66.9, 66.3,

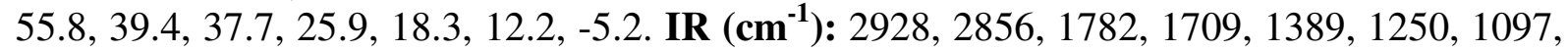
836, 776, 701. MS (ESI): $474.2\left(\mathrm{M}+\mathrm{Na}^{+}\right), 925.0\left(2 \mathrm{M}+\mathrm{Na}^{+}\right)$. HRMS (CI): calculated 452.2468, found $452.2470\left(\mathrm{M}+\mathrm{H}^{+}\right)$. $[\alpha]_{\mathrm{D}}{ }^{22}-10.7\left(c 1.49, \mathrm{CH}_{2} \mathrm{Cl}_{2}\right)$.

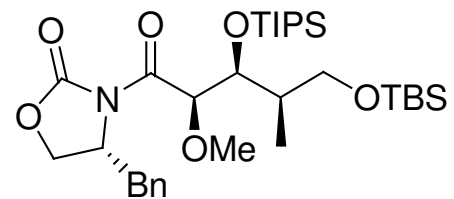

of $\mathrm{NaHCO}_{3}(100 \mathrm{~mL})$ was added. The organic phase was separated and the aqueous phase was extracted with $100 \mathrm{~mL}$ of $\mathrm{CH}_{2} \mathrm{Cl}_{2}$. The combined extracts were dried with $\mathrm{Na}_{2} \mathrm{SO}_{4}$ and concentrated. Silica gel chromatography of the residue (ethyl acetate/ cyclohexane, 1:9) afforded the desired product $\mathbf{1 4}$ as a pale yellow oil (9.91 g, 53\% on 2 steps). ${ }^{\mathbf{1}} \mathbf{H}$ NMR (300 MHz, $\left.\mathbf{C D C l}_{3}\right)$ : 7.35-7.21 (m, 5H), $5.18(\mathrm{~d}, J=6.8 \mathrm{~Hz}, 1 \mathrm{H}), 4.63-4.56(\mathrm{~m}, 1 \mathrm{H}), 4.31(\mathrm{dd}, J=$ 7.2, 2.6, 1H), 4.22-4.12 (m, 2H), $3.66(\mathrm{dd}, J=9.8,6.8 \mathrm{~Hz}, 1 \mathrm{H}), 3.45-3.38(\mathrm{~m}, 2 \mathrm{H}), 3.40(\mathrm{~s}$, $3 \mathrm{H}), 2.76(\mathrm{dd}, J=13.2,9.8 \mathrm{~Hz}, 1 \mathrm{H}), 1.58-1.50(\mathrm{~m}, 1 \mathrm{H}), 1.10-1.04(\mathrm{br}, 21 \mathrm{H}), 0.91(\mathrm{~d}, J=$ $7.1 \mathrm{~Hz}, 3 \mathrm{H}), 0.87(\mathrm{~s}, 9 \mathrm{H}), 0.00(\mathrm{~s}, 6 \mathrm{H}) .{ }^{13} \mathbf{C}$ NMR (75 MHz, CDCl $\left.\mathbf{3}\right): 172.7,153.4,135.5$, $129.8,129.4,127.8,74.1,66.8,65.9,58.1,56.6,40.4,38.2,26.3,18.7,13.7,11.5,-5.0$. IR $\left(\mathbf{c m}^{-1}\right): 2941,2865,1788,1705,1464,1385,1110,835,679$. MS (ESI): $630.3\left(\mathrm{M}+\mathrm{Na}^{+}\right)$. HRMS (CI): calculated 608.3803, found $608.3800\left(\mathrm{M}+\mathrm{H}^{+}\right)$. [ $\left.\alpha\right]_{\mathrm{D}}{ }^{22}-23.8\left(c 1.85, \mathrm{CH}_{2} \mathrm{Cl}_{2}\right)$.<smiles>CO[C@H]1C(=O)OC[C@@H](C)[C@H]1O</smiles>

Compound f: To a solution of $20 \mathrm{mg}$ of $\mathbf{1 4}(0.0344 \mathrm{mmol})$ in $0.5 \mathrm{~mL}$ of THF were added $0.5 \mathrm{~mL}$ of $\mathrm{HF} \bullet$ pyridine. The reaction was stirred $2 \mathrm{hrs}$ at $\mathrm{RT}$ and diluted with $3 \mathrm{~mL}$ of water and $3 \mathrm{~mL}$ of AcOEt. The organic phase was separated and the aqueous phase was extracted with $3 \mathrm{~mL}$ of EtOAc. The combined extracts were washed with $5 \mathrm{~mL}$ of a saturated aqueous solution of $\mathrm{NaHCO}_{3}$, dried with $\mathrm{Na}_{2} \mathrm{SO}_{4}$ and concentrated. Silica gel chromatography of the residue (ethyl acetate/ cyclohexane, 7:3) afforded as a colorless oil the lactone f $(3.7 \mathrm{mg}, .72 \%) .{ }^{1} \mathbf{H}$ NMR (300 
MHz, $\left.\mathbf{C D C l}_{3}\right): 4.31(\mathrm{dd}, J=11.6,4.9 \mathrm{~Hz}, 1 \mathrm{H}), 3.86(\mathrm{dd}, J=11.6,9.0 \mathrm{~Hz}, 1 \mathrm{H}), 3.71(\mathrm{~s}, 3 \mathrm{H})$, $3.66(\mathrm{~d}, J=9.0 \mathrm{~Hz}, 1 \mathrm{H}), 3.57(\mathrm{t}, J=9.0 \mathrm{~Hz}, 1 \mathrm{H}), 2.62-2.57(\mathrm{br}, 1 \mathrm{H}), 2.20-2.09(\mathrm{~m}, 1 \mathrm{H}), 1.12$ $(\mathrm{d}, J=6.8 \mathrm{~Hz}, 3 \mathrm{H}) .{ }^{13} \mathbf{C}$ NMR (75 MHz, $\left.\mathbf{C D C l}_{3}\right): 171.0,82.8,74.5,71.1,61.0,35.8,14.5$.

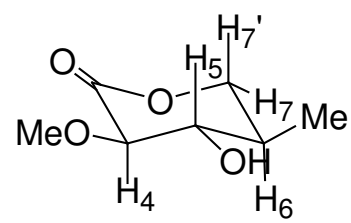

$J_{\mathrm{H} 4^{-} \mathrm{H} 5}=9.0 \mathrm{~Hz}$
$J_{\mathrm{H} 5^{-} \mathrm{H} 6}=9.0 \mathrm{~Hz}$
$J_{\mathrm{H} 6^{-} \mathrm{H} 7}=4.9 \mathrm{~Hz}$
$J_{\mathrm{H} 6^{-} \mathrm{H} 7}=9.0 \mathrm{~Hz}$

The coupling constants H4-H5 $(9.0 \mathrm{~Hz})$ and H5-H6 $(9.0 \mathrm{~Hz})$ demonstrate that H4, H5 and $\mathrm{H} 6$ are axial.<smiles>CO[C@H](C(=O)N1C(=O)OC[C@H]1Br)[C@H](OC)[C@H](C)C=O</smiles>

Compound 15: A suspension of $5.03 \mathrm{~g}$ of $14(8.3 \mathrm{mmol}), 8.9 \mathrm{~g}$ of PCC (41 mmol), $5 \mathrm{~g}$ of $\mathrm{MgSO}_{4}$ and $5 \mathrm{~g}$ of celite in $50 \mathrm{~mL}$ of $\mathrm{CH}_{2} \mathrm{Cl}_{2}$ was stirred 3 days at RT. The suspension was then filtered on a pad of celite with AcOEt $(150 \mathrm{~mL})$. The filtrate was then concentrated. Silica gel chromatography of the residue (ethyl acetate/ cyclohexane, 2:8) afforded the desired product 15 as a pale yellow oil (3.35 g, 82\%). ${ }^{\mathbf{1}} \mathbf{H}$ NMR (300 $\left.\mathbf{M H z}, \mathbf{C D C l}_{\mathbf{3}}\right)$ : 9.99 (s, 1H), 7.35-7.20 (m, 5H), $4.92(\mathrm{~d}, J=2.5 \mathrm{~Hz}, 1 \mathrm{H}), 4.66-4.63(\mathrm{q}, J=2.5 \mathrm{~Hz}, 1 \mathrm{H}), 4.63-4.56(\mathrm{~m}, 1 \mathrm{H})$, 4.29-4.15 (m, 2H), 3.35-3.30 (m, 1H), $3.31(\mathrm{~s}, 3 \mathrm{H}), 2.87(\mathrm{dd}, J=13.3,9.5 \mathrm{~Hz}, 1 \mathrm{H}), 2.59$ (qd, $J=7.0,1.8 \mathrm{~Hz}, 1 \mathrm{H}), 1.11(\mathrm{~d}, J=7.0 \mathrm{~Hz}, 3 \mathrm{H}), 1.10-1.05(\mathrm{br}, 21 \mathrm{H}) .{ }^{13} \mathbf{C}$ NMR $(\mathbf{7 5} \mathbf{~ M H z}$, $\left.\mathbf{C D C l}_{3}\right):$ 202.1, 169.5, 153.3, 134.8, 129.4, 129.4, 127.6, 80.5, 75.1, 67.0, 58.5, 56.0, 50.6, $37.5,18.1,12.9,9.8 . \mathbf{I R}\left(\mathbf{c m}^{-1}\right): 2946,2867,1780,1719,1455,1389,1196,1110,998,882$, 702, 676. MS (CI) : $492\left(\mathrm{M}+\mathrm{H}^{+}\right)$. HRMS (CI): calculated 492.2781, found 492.2789 $\left(\mathrm{M}+\mathrm{H}^{+}\right) \cdot[\alpha]_{\mathrm{D}}{ }^{22}+47.7\left(c 0.78, \mathrm{CH}_{2} \mathrm{Cl}_{2}\right)$.<smiles>C=C[C@H](C)[C@H](O)[C@H](C)[C@H](O[In])[C@H](OC)C(=O)N1C(=O)OC[C@H]1Cc1ccccc1</smiles>

Lactone 36 and alcohol 16: To $25 \mathrm{~mL}$ of THF at $-78^{\circ} \mathrm{C}$ were added: $10.2 \mathrm{~mL}$ of a $1 \mathrm{M}$ solution of potassium tert-butoxide $(10.2 \mathrm{mmol})$ and $4.2 \mathrm{~mL}$ of a $2.4 \mathrm{M}$ solution of butyllithium $(10.2 \mathrm{mmol})$ and an excess of trans-2-butene. The mixture was stirred $1 \mathrm{hr}$ at $-40^{\circ} \mathrm{C}$, cooled to $-78^{\circ} \mathrm{C}$ and $2.11 \mathrm{~mL}$ of 2-isopropoxy-4,4,5,5-tetramethyl1,3,2-dioxaborolane was added $(10.3 \mathrm{mmol})$. The mixture was stirred $1 \mathrm{hr}$ at $-78^{\circ} \mathrm{C}$ and 1.3 $\mathrm{mL}$ of boron trifluoride-etherate $(10.3 \mathrm{mmol})$ were added. After $10 \mathrm{~min}$ of stirring, $1192 \mathrm{mg}$ of aldehyde $15(2.4 \mathrm{mmol})$ in $3 \mathrm{~mL}$ of THF were added. The reaction was stirred $5 \mathrm{hrs}$ at $78^{\circ} \mathrm{C}$ and then diluted with $30 \mathrm{~mL}$ of a saturated aqueous solution of $\mathrm{NaHCO}_{3}$ and $20 \mathrm{~mL}$ of EtOAc. The organic phase was separated and the aqueous phase was extracted with $30 \mathrm{~mL}$ of EtOAc. The combined extracts were dried with $\mathrm{Na}_{2} \mathrm{SO}_{4}$ and concentrated. Silica gel chromatography of the residue (ethyl acetate/ cyclohexane, 1:9 to 3:7) afforded as a colorless oil a mixture of the lactone 36 and 2 diastereoisomers in a 9:1:1 ratio (174 $\mathrm{mg}, 20 \%)$ and a 9:1 mixture of alcohol 16 with a diastereoisomer and unknown impurities $(670 \mathrm{mg})$. Mixture of lactone 36 and diastereoisomers and mixture of alcohol 16 with one diastereoisomer were used as it is in the next steps. Separations were effected at the next steps.

\section{9:1:1 mixture of lactone 36 and diastereoisomers:}

${ }^{1} \mathbf{H}$ NMR (300 MHz, $\mathbf{C D C l}_{3}$ ): 5.90 (ddd, $\left.J=17.3,10.4,7.2 \mathrm{~Hz}, 0.9 \mathrm{H}\right), 5.80$ (ddd, $J=17.0$, $10.2,8.8 \mathrm{~Hz}, 0.1 \mathrm{H}), 5.63(\mathrm{ddd}, J=17.3,10.2,9.0 \mathrm{~Hz}, 0.1 \mathrm{H}), 5.15(\mathrm{~d}, J=17.3 \mathrm{~Hz}, 1 \mathrm{H}), 5.10$ $(\mathrm{d}, J=10.4 \mathrm{~Hz}, 1 \mathrm{H}), 4.23(\mathrm{dd}, J=9.8,1.5 \mathrm{~Hz}, 1 \mathrm{H}), 3.76(\mathrm{~d}, J=5.0 \mathrm{~Hz}, 1 \mathrm{H}), 3.73(\mathrm{dd}, J=5.0$, 
$0.9 \mathrm{~Hz}, 1 \mathrm{H}), 3.56(\mathrm{~s}, 3 \mathrm{H}) 2.51-2.42(\mathrm{~m}, 1 \mathrm{H}), 2.12-2.07(\mathrm{~m}, 1 \mathrm{H}), 1.14-1.02(\mathrm{br}, 21 \mathrm{H}), 0.99(\mathrm{~d}, J$ $=6.9 \mathrm{~Hz}, 3 \mathrm{H}), 0.91(\mathrm{~d}, J=7.5 \mathrm{~Hz}, 3 \mathrm{H})$. See full characterisation of pure 36 below:

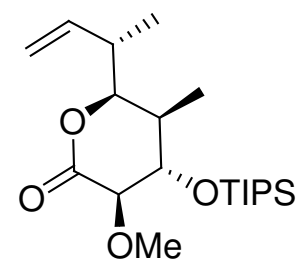

Compound 36: To a solution of $9 \mathrm{mg}$ of the 9:1 mixture of alcohol 16 with a diastereoisomer and unknown impurities at $-78^{\circ} \mathrm{C}$ in $0.5 \mathrm{Ml}$ of THF were added $18 \mu \mathrm{L}$ of a $2 \mathrm{M}$ solution of LDA in THF $(0.036 \mathrm{mmol})$. The reaction was stirred $1 \mathrm{hr}$ at $-78^{\circ} \mathrm{C}$. The mixture was diluted with $3 \mathrm{~mL}$ of a saturated aqueous solution of $\mathrm{NaHCO}_{3}$ and $3 \mathrm{~mL}$ of EtOAc. The organic phase was separated and the aqueous phase was extracted with $3 \mathrm{~mL}$ of EtOAc. The combined extracts were dried with $\mathrm{Na}_{2} \mathrm{SO}_{4}$ and concentrated. Silica gel chromatography of the residue (ethyl acetate/ cyclohexane, 1:9) afforded as a colorless oil the desired lactone M1 (8 $\mathrm{mg}, 40 \%$ on 2 steps) without any diastereoisomers. ${ }^{1} \mathbf{H}$ NMR (300 $\left.\mathbf{~ M H z}, \mathbf{C D C l}_{3}\right): 5.90$ (ddd, $J=17.3,10.4,7.2 \mathrm{~Hz}, 1 \mathrm{H}), 5.15(\mathrm{~d}, J=17.3 \mathrm{~Hz}, 1 \mathrm{H}), 5.10(\mathrm{~d}, J=10.4 \mathrm{~Hz}, 1 \mathrm{H}), 4.23$ $(\mathrm{dd}, J=9.8,1.5 \mathrm{~Hz}, 1 \mathrm{H}), 3.76(\mathrm{~d}, J=5.0 \mathrm{~Hz}, 1 \mathrm{H}), 3.73(\mathrm{dd}, J=5.0,0.9 \mathrm{~Hz}, 1 \mathrm{H}), 3.56(\mathrm{~s}, 3 \mathrm{H})$ 2.51-2.42 (m, 1H), 2.12-2.07 (m,1H), 1.14-1.02 (br, 21H), $0.99(\mathrm{~d}, J=6.9 \mathrm{~Hz}, 3 \mathrm{H}), 0.91(\mathrm{~d}, J$ $=7.5 \mathrm{~Hz}, 3 \mathrm{H}) .{ }^{13} \mathbf{C}$ NMR (75 MHz, $\left.\mathbf{C D C l}_{3}\right):$ 171.1, 139.8, 115.5, 83.6, 80.5, 77.5, 59.7, 40.3, 38.2, 17.9, 17.8, 17.7, 15.2, 12.1, 10.9. IR $\left(\mathbf{c m}^{-1}\right): 2939,2865,1760,1462,1196,1100,993$, 680. MS (ESI): $370.9\left(\mathrm{M}+\mathrm{Na}^{+}\right), 763.0\left(2 \mathrm{M}+\mathrm{Na}^{+}\right)$. HRMS (CI): calculated 371.2618, found $371.2617\left(\mathrm{M}+\mathrm{H}^{+}\right) \cdot[\alpha]_{\mathrm{D}}{ }^{22}+26.1\left(c 0.60, \mathrm{CH}_{2} \mathrm{Cl}_{2}\right)$.

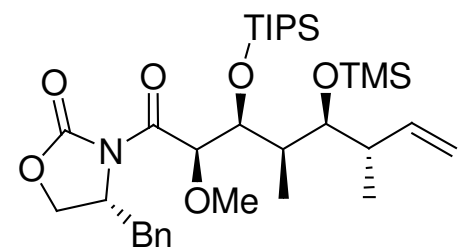

Compound 17: To a solution of the $670 \mathrm{mg}$ of alcohol 16 with impurities in $15 \mathrm{~mL}$ of $\mathrm{CH}_{2} \mathrm{Cl}_{2}$ were added at $0^{\circ} \mathrm{C}: 1.03 \mu \mathrm{L}$ of $\mathrm{Et}_{3} \mathrm{~N}(7.4 \mathrm{mmol})$ and $638 \mu \mathrm{L}$ of TMS triflate $(3.3 \mathrm{mmol})$. The reaction was stirred $3 \mathrm{hrs}$ at $\mathrm{RT}$ and then diluted with $10 \mathrm{~mL}$ of a saturated aqueous solution of $\mathrm{NaHCO}_{3}$ and $10 \mathrm{~mL}$ of $\mathrm{CH}_{2} \mathrm{Cl}_{2}$. The organic phase was separated and the aqueous phase was extracted with $10 \mathrm{~mL}$ of $\mathrm{CH}_{2} \mathrm{Cl}_{2}$. The combined extracts were dried with $\mathrm{Na}_{2} \mathrm{SO}_{4}$ and concentrated. Silica gel chromatography of the residue (ethyl acetate/ cyclohexane, 1:9) afforded as a pale yellow oil a 9:1 mixture of the desired compound 17 and a diastereoisomer (635 mg, $42 \%$ on 2 steps). Separation was effected at the next step. ${ }^{1} \mathbf{H}$ NMR (300 $\left.\mathbf{~ M H z}, \mathbf{C D C l}_{3}\right): 7.38-7.21(\mathrm{~m}, 5 \mathrm{H}), 5.90$ (ddd, $J=$ $17.3,10.2,7.2 \mathrm{~Hz}, 0.1 \mathrm{H}), 5.72(\mathrm{ddd}, J=17.3,10.2,9.0 \mathrm{~Hz}, 0.9 \mathrm{H}), 5.28(\mathrm{~d}, J=9.0 \mathrm{~Hz}, 1 \mathrm{H})$, $5.06(\mathrm{dd}, J=17.3,2.6 \mathrm{~Hz}, 1 \mathrm{H}), 4.98(\mathrm{dd}, J=10.2,2.6 \mathrm{~Hz}, 1 \mathrm{H}), 4.58-4.49(\mathrm{~m}, 1 \mathrm{H}), 4.26(\mathrm{~d}, J$ $=8.3 \mathrm{~Hz}, 1 \mathrm{H}), 4.18-4.15(\mathrm{~m}, 2 \mathrm{H}), 3.62(\mathrm{~d}, J=9.8 \mathrm{~Hz}, 1 \mathrm{H}), 3.45(\mathrm{dd}, J=13.2,3.0 \mathrm{~Hz}, 1 \mathrm{H})$, $3.38(\mathrm{~s}, 3 \mathrm{H}), 2.73(\mathrm{dd}, J=13.2,10.2 \mathrm{~Hz}, 1 \mathrm{H}), 2.50-2.39(\mathrm{~m}, 1 \mathrm{H}), 1.34-1.24(\mathrm{~m}, 1 \mathrm{H}), 1.15-$ $1.15(\mathrm{br}, 21 \mathrm{H}), 1.05(\mathrm{~d}, J=6.8 \mathrm{~Hz}, 3 \mathrm{H}), 0.95(\mathrm{~d}, J=6.8 \mathrm{~Hz}, 3 \mathrm{H}), 0,12(\mathrm{~m}, 9 \mathrm{H}) .{ }^{\mathbf{1 3}} \mathbf{C}$ NMR $(\mathbf{7 5}$ MHz, $\left.\mathbf{C D C l}_{3}\right)$ : $172.7,153.1,139.6,135.3,129.5,129.2,127.5,115.6,78.2,74.4,66.5,57.2$, 56.4, 40.8, 40.1, 37.9, 19.6, 18.7, 13.9, 11.6, 1.0. IR (cm $\left.{ }^{-1}\right): 2968,2864,1777,1701,1455$, 1294, 1192, 1106, 878, 833. MS (ESI): $642.3\left(\mathrm{M}+\mathrm{Na}^{+}\right), 1261.3\left(2 \mathrm{M}+\mathrm{Na}^{+}\right)$. HRMS (LSIMS): calculated 620.3803, found $620.3808\left(\mathrm{M}+\mathrm{H}^{+}\right)$. $[\alpha]_{\mathrm{D}}{ }^{22}-29.4\left(c 1.55, \mathrm{CH}_{2} \mathrm{Cl}_{2}\right)$.

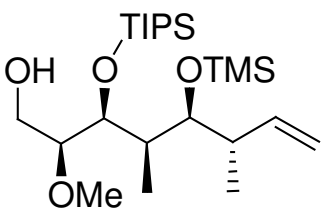

To a solution of $600 \mathrm{mg}(0.97 \mathrm{mmol})$ of $\mathbf{1 7}$ in $6 \mathrm{~mL}$ of THF at $0^{\circ} \mathrm{C}$ were added $2.4 \mathrm{~mL}$ of a $2 \mathrm{M}$ solution of lithium borohydryde in THF (4.85 mmol). The reaction was stirred $3 \mathrm{hrs}$ at $\mathrm{RT}$ and then diluted with $10 \mathrm{~mL}$ of a saturated aqueous solution of $\mathrm{NaHCO}_{3}$ and $10 \mathrm{~mL}$ of $\mathrm{Et}_{2} \mathrm{O}$. The organic phase was separated and the aqueous phase was extracted with $10 \mathrm{~mL}$ of $\mathrm{Et}_{2} \mathrm{O}$. The combined extracts were dried with $\mathrm{Na}_{2} \mathrm{SO}_{4}$ and concentrated. Silica gel chromatography of the residue (ethyl acetate/ cyclohexane, 1:9) afforded as a pale yellow oil the desired alcohol (270 mg, 62\%). ${ }^{1} \mathbf{H}$ NMR (300 MHz, $\mathbf{C D C l}_{3}$ ): 5.85 (ddd, $J=16.8,10.9$, 
$8.4 \mathrm{~Hz}, 1 \mathrm{H}), 5.06-4.99(\mathrm{~m}, 2 \mathrm{H}), 4.08(\mathrm{dd}, J=7.2,2.0 \mathrm{~Hz}, 1 \mathrm{H}), 3.85(\mathrm{dd}, J=12.3,3.4 \mathrm{~Hz}$, $1 \mathrm{H}), 3.66$ (dd, $J=9.0,2.0 \mathrm{~Hz}, 1 \mathrm{H}), 3.54$ (dd, $J=12.3,3.8 \mathrm{~Hz}, 1 \mathrm{H}), 3.38$ (s, 3H), 2.24 (dt, $J=$ 7.2, $3.4 \mathrm{~Hz}, 1 \mathrm{H}), 2.52-2.42(\mathrm{~m}, 1 \mathrm{H}), 1.80-1.63(\mathrm{~m}, 2 \mathrm{H}), 1.11-1.08(\mathrm{br}, 21 \mathrm{H}), 1.04(\mathrm{~d}, J=7.2$ $\mathrm{Hz}, 3 \mathrm{H}), 0.90(\mathrm{~d}, J=6.8 \mathrm{~Hz}, 3 \mathrm{H}), 0.13$ (s, 9H). ${ }^{13} \mathbf{C}$ NMR (75 MHz, CDCl $\left.\mathbf{3}\right):$ 140.4, 115.3, 84.7, 78.4, 72.2, 59.6, 57.2, 40.9, 39.3, 19.3, 18.7, 13.7, 11.2, 1.1. IR $\left(\mathbf{c m}^{-1}\right): 3288,2944$, $2865,1463,1384,1249,1142,1041,800 .[\alpha]_{\mathbf{D}}{ }^{22}+11.5\left(c 0.29, \mathrm{CH}_{2} \mathrm{Cl}_{2}\right)$.<smiles></smiles>

Compound 18: To a solution of $130 \mathrm{mg}$ of the preceding alcohol $(0.29 \mathrm{mmol})$ and $153 \mu \mathrm{L}$ of pyridine $(1.9 \mathrm{mmol})$ in $2 \mathrm{~mL}$ of $\mathrm{CH}_{2} \mathrm{Cl}_{2}$ were added $246 \mathrm{mg}$ of Dess-Martin periodinane $(0.58 \mathrm{mmol})$. The reaction was stirred $2 \mathrm{hrs}$ and diluted with $2 \mathrm{~mL}$ of a saturated aqueous solution of $\mathrm{Na}_{2} \mathrm{~S}_{2} \mathrm{O}_{3}, 2 \mathrm{~mL}$ of a saturated aqueous solution of $\mathrm{NaHCO}_{3}$ and $4 \mathrm{ml}$ of $\mathrm{CH}_{2} \mathrm{Cl}_{2}$. The organic phase was separated and the aqueous phase was extracted with $4 \mathrm{~mL}$ of $\mathrm{CH}_{2} \mathrm{Cl}_{2}$. The combined extracts were dried with $\mathrm{Na}_{2} \mathrm{SO}_{4}$ and concentrated. Silica gel chromatography of the residue (ethyl acetate/ cyclohexane, 1:9) afforded as a colorless oil the desired compound $18(69 \mathrm{mg}, 54 \%)$. ${ }^{\mathbf{1}} \mathbf{H}$ NMR (300 MHz, $\left.\mathbf{C D C l}_{3}\right)$ : 9.53 (d, $J$ $=3.0 \mathrm{~Hz}, 1 \mathrm{H}), 5.75(\mathrm{ddd}, J=17.2,10.3,9.0 \mathrm{~Hz}, 1 \mathrm{H}), 5.00-4.89(\mathrm{~m}, 2 \mathrm{H}), 4.19(\mathrm{dd}, J=7.2,2.6$ $\mathrm{Hz}, 1 \mathrm{H}), 3.66(\mathrm{dd}, J=8.3,2.6 \mathrm{~Hz}, 1 \mathrm{H}), 3.60(\mathrm{dd}, J=7.2,3.4 \mathrm{~Hz}, 1 \mathrm{H}), 3.33$ (s, 3H), 2.47-2.36 $(\mathrm{m}, 1 \mathrm{H}), 1.61-1.51(\mathrm{~m}, 1 \mathrm{H}), 1.11-1.07(\mathrm{br}, 21 \mathrm{H}), 1.00(\mathrm{~d}, J=7.2 \mathrm{~Hz}, 3 \mathrm{H}), 0.95(\mathrm{~d}, J=6.8 \mathrm{~Hz}$, 3H), 0.11 (s, 9H). ${ }^{13} \mathbf{C}$ NMR (75 MHz, $\left.\mathbf{C D C l}_{3}\right):$ 201.3, 140.4, 115.3, 89.5, 77.3, 72.5, 57.9, 41.4, 40.0, 19.1, 18.6, 13.5, 10.8, 1.1. IR $\left(\mathbf{c m}^{-1}\right): 2995,2895,1690,1125,1105,884 . \mathbf{M S}$ (ESI): $445.0\left(\mathrm{M}+\mathrm{H}^{+}\right) .[\alpha]_{\mathbf{D}}{ }^{22}+15.4\left(c \quad 0.35, \mathrm{CH}_{2} \mathrm{Cl}_{2}\right)$.

*Assembly of the Soraphen A framework

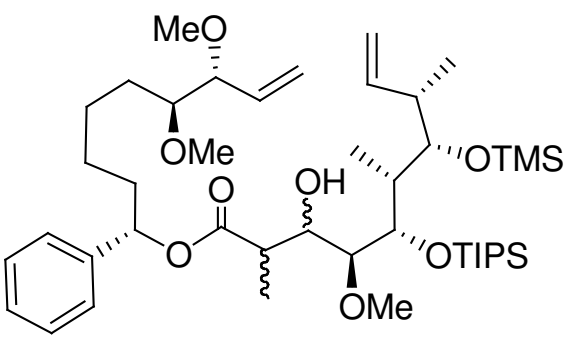

Compound 21: To a solution of $83 \mathrm{mg}$ of ester $2(0.25$ $\mathrm{mmol}$ ) in $0.5 \mathrm{~mL}$ of $\mathrm{THF}$ at $-78^{\circ} \mathrm{C}$ were added dropwise $150 \mu \mathrm{L}$ of a $2 \mathrm{M}$ solution of LDA $(0.30 \mathrm{mmol})$ in THF. The reaction was stirred $35 \mathrm{~min}$ at $-78^{\circ} \mathrm{C}$ and $65 \mathrm{mg}$ of aldehyde $18(0.146 \mathrm{mmol})$ in $0.3 \mathrm{~mL}$ of THF was added dropwise and the reaction was stirred $4 \mathrm{hrs}$ at $-78^{\circ} \mathrm{C}$. The mixture was diluted with $3 \mathrm{~mL}$ of a saturated aqueous solution of $\mathrm{NaHCO}_{3}$ and $3 \mathrm{~mL}$ of EtOAc. The organic phase was separated and the aqueous phase was extracted with $3 \mathrm{~mL}$ of EtOAc. The combined extracts were dried with $\mathrm{Na}_{2} \mathrm{SO}_{4}$ and concentrated. Silica gel chromatography of the residue (ethyl acetate/ cyclohexane, 1:9) afforded as a colorless oil a 3:1 mixture of 2 diastereoisomers of the desired compound 21 (76.1 mg, 67\%). ${ }^{1} \mathbf{H}$ NMR (500 MHz, $\left.\mathbf{C D C l}_{3}\right):$ 7.35-7.26 (m, 5H), 5.88-5.67 (m, 3H), 5.29 $(\mathrm{dd}, J=10.5,1.3 \mathrm{~Hz}, 1 \mathrm{H}), 5.23(\mathrm{dd}, J=17.3,1.3 \mathrm{~Hz}, 1 \mathrm{H}), 5.08-5.01(\mathrm{~m}, 2 \mathrm{H}), 4.14-4.07$ (m, $1 \mathrm{H}), 3.71-3.49(\mathrm{~m}, 3 \mathrm{H}), 3.46(\mathrm{~s}, 1 \mathrm{H}), 3.40-3.37$ (br, 5H) $3.28(\mathrm{~s}, 3 \mathrm{H}), 3.17-3.12(\mathrm{~m}, 1 \mathrm{H}), 3.08$ $(\mathrm{d}, J=7.9 \mathrm{~Hz}, 0,75 \mathrm{H}), 2.98(\mathrm{~d}, J=9.3 \mathrm{~Hz}, 0.25 \mathrm{H}), 2.71-2.58(\mathrm{~m}, 2 \mathrm{H}), 2.49-2.41(\mathrm{~m}, 0.75 \mathrm{H})$, 2.28-2.23 (m, 0.25H), 2.00-1.85 (m, 1H), 1.84-1.70 (m, 1H), 1.70-1.57 (m, 1H), 1.47-1.24 (m, $3 \mathrm{H}), 1.21-1.15(\mathrm{~m}, 3 \mathrm{H}), 1.13-1.08(\mathrm{~m}, 21 \mathrm{H}), 1.07-1.01(\mathrm{~m}, 3 \mathrm{H}), 0.95-0.89(\mathrm{~m}, 5.25 \mathrm{H}), 0.77$ $(\mathrm{d}, \mathrm{J}=6.8 \mathrm{~Hz}, 0.75 \mathrm{H}), 0.14(\mathrm{~s}, 9 \mathrm{H}) .{ }^{13} \mathbf{C}$ NMR (125 MHz, CDCl $): 174.3,140.7,140.4$, $140.0,139.8,135.4,128.6,128.4,126.6,119.0,115.8,115.5,84.8,83.5,82.9,82.1,78.7$, $76.1,72.2,71.9,71.7,61.0,60.9,58.5,56.8,45.3,44.8,41.1,39.9,36.3,30.4,26.4,25.7$, $25.6,19.8,19.6,18.7,18.6,14.6,14.4,14.1,13.7,12.4,11.2,11.0,1.2 . \mathbf{I R}\left(\mathbf{c m}^{-1}\right): 2938$, $2860,1731,1456,1249,1098,882,837$. 


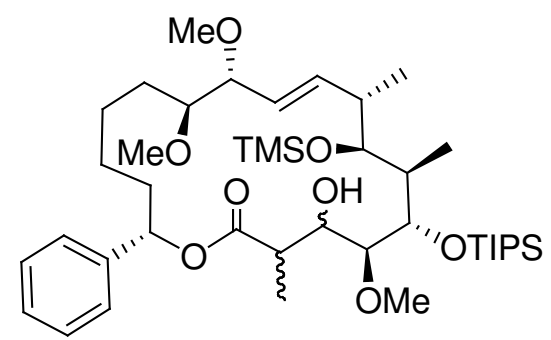

Compound 22: To a solution of $14 \mathrm{mg}$ of the diene 21 $(0.017 \mathrm{mmol})$ in $1 \mathrm{~mL}$ of degassed toluene were added 3.0 $\mathrm{mg}$ of Grubbs-Hoveyda II catalyst $24(0.005 \mathrm{mmol})$. The reaction was stirred $15 \mathrm{hrs}$ at $80^{\circ} \mathrm{C}$ and the solvent was then evaporated. Silica gel chromatography of the residue (ethyl acetate/ cyclohexane, 2:8) afforded as a colorless oil the desired compound $\mathbf{2 2}$ as a mixture of diastereoisomers (4 $\mathrm{mg}, 30 \%)$ and the isomerised compound $23(6 \mathrm{mg}, 43 \%) .{ }^{\mathbf{1}} \mathbf{H}$ NMR (300 $\left.\mathbf{~ M H z}, \mathbf{C D C l}_{3}\right)$ :7.36$7.28(\mathrm{~m}, 5 \mathrm{H}), 5.89$ (dd, $J=16.0,7.5 \mathrm{~Hz}, 1 \mathrm{H}), 5.71(\mathrm{dd}, J=10.5,2.8 \mathrm{~Hz}, 1 \mathrm{H}), 5.28(\mathrm{dd}, J=$ 16.0, $5.3 \mathrm{~Hz}, 1 \mathrm{H}), 4.14-4.03(\mathrm{~m}, 1 \mathrm{H}), 3.94-3.78(\mathrm{~m}, 1 \mathrm{H}), 3.77-3.53(\mathrm{~m}, 1 \mathrm{H}), 3.45-3.31(\mathrm{~m}$, $10 \mathrm{H}), 3.28-3.16(\mathrm{~m}, 1 \mathrm{H}), 3.15-3.07(\mathrm{~m}, 1 \mathrm{H}), 2.63-2.55(\mathrm{~m}, 2 \mathrm{H}), 2.03-1.84(\mathrm{~m}, 2 \mathrm{H}), 1.73-1.30$ $(\mathrm{m}, 8 \mathrm{H}), 1.30-1.25(\mathrm{~m}, 3 \mathrm{H}), 1.16-1.04(\mathrm{br}, 21 \mathrm{H}), 0.96(\mathrm{~d}, \mathrm{~J}=6.8 \mathrm{~Hz}, 3 \mathrm{H}), 0.95(\mathrm{~d}, \mathrm{~J}=6.8 \mathrm{~Hz}$, $3 \mathrm{H}), 0.13(\mathrm{~s}, 9 \mathrm{H})$. MS (ESI): $773.4\left(\mathrm{M}+\mathrm{Na}^{+}\right)$. HRMS (ESI): calculated 773.4814, found $773.4807\left(\mathrm{M}+\mathrm{Na}^{+}\right)$.

* Olefin isomerization during metathesis

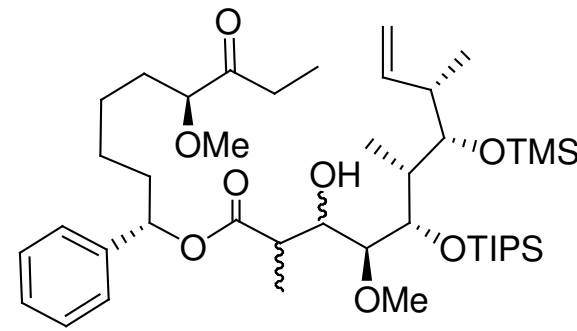

Compound 23: ${ }^{1} \mathrm{H}$ NMR (300 $\left.\mathbf{M H z}, \mathrm{CDCl}_{3}\right)$ : 7.37-7.27 $(\mathrm{m}, 5 \mathrm{H}), 5.98-5.62(\mathrm{~m}, 2 \mathrm{H}), 5.10-4.96(\mathrm{~m}, 2 \mathrm{H}), 4.24-3.92$ $(\mathrm{m}, 1 \mathrm{H}), 3.78-2.98(\mathrm{~m}, 11 \mathrm{H}), 2.78-2.55(\mathrm{~m}, 2 \mathrm{H}), 2.54-$ $2.42(\mathrm{~m}, 2 \mathrm{H}), 2.00-1.86(\mathrm{~m}, 1 \mathrm{H}), 1.85-1.70(\mathrm{~m}, 1 \mathrm{H}), 1.70-$ 0.86 (m, 40H), 0.16-.0.13 (br, 9H). MS (ESI): 787.4 $\left(\mathrm{M}+\mathrm{Na}^{+}\right)$.

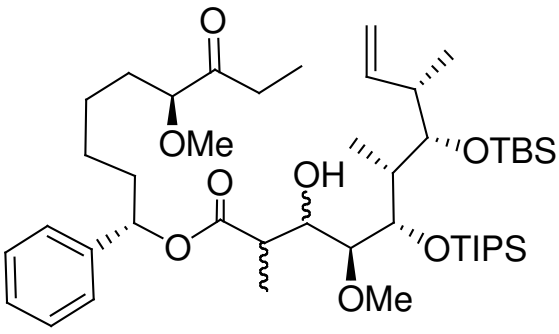

Compound 33: ${ }^{1} \mathbf{H}$ NMR (300 $\left.\mathbf{M H z}, \mathbf{C D C l}_{3}\right)$ : 7.35-7.26 $(\mathrm{m}, 5 \mathrm{H}), 5.96-5.83(\mathrm{~m}, 1 \mathrm{H}), 5.76-5.67(\mathrm{~m}, 1 \mathrm{H}), 5.06-4.99$ $(\mathrm{m}, 2 \mathrm{H}), 4.13-3.94(\mathrm{~m}, 1 \mathrm{H}), 3.71-3.54(\mathrm{~m}, 3 \mathrm{H}), 3.49-3.46$ $(\mathrm{m}, 2 \mathrm{H}), 3.39-3.34(\mathrm{~m}, 3 \mathrm{H}), 3.32-3.23(\mathrm{~m}, 2 \mathrm{H}), 3.09-2.98$ (m, 1H), 2.67-2.60 (m, 2H), 2.50-2.38 (m, 2H), 2.01-1.86 (m, 1H), 1.85-1.76 (m, 1H), 1.70-0.86 (m, 36H), 1.06 (d, $J$ $=7.5 \mathrm{~Hz}, 3 \mathrm{H}), 0.93-0.88(\mathrm{br}, 12 \mathrm{H}), 0.07$ (s, 6H). MS

(ESI): $829.4\left(\mathrm{M}+\mathrm{Na}^{+}\right)$.

*Cross-metathesis avenue to seco-Soraphen A.<smiles>CCC(=O)O[C@H](CCCCC(OC)[C@@H](/C=C/[C@@H](C)[C@H]1OC(=O)[C@H](OC)[C@H](OC)[C@H]1C)OC)c1ccccc1</smiles>

Compound 37: To a solution of $35 \mathrm{mg}$ of $\mathbf{3 6}(0.094$ $\mathrm{mmol})$ and $63 \mathrm{mg}$ of $\mathbf{F}(0.188 \mathrm{mmol})$ in $1 \mathrm{~mL}$ of degassed toluene were added $19 \mathrm{mg}$ of Grubbs-Hoveyda II catalyst $(0.062 \mathrm{mmol})$ in 3 portions. The reaction was stirred 30 hrs at $80^{\circ} \mathrm{C}$ and the solvent was then evaporated. Silica gel chromatography of the residue (ethyl acetate/ cyclohexane, $2: 8)$ afforded as a colorless oil the desired compound $\mathbf{3 7}$ $\left.\mathbf{C D C l}_{3}\right): 7.32-7.26(\mathrm{~m}, 5 \mathrm{H}), 5.75-5.71(\mathrm{~m}, 2 \mathrm{H}), 5.48(\mathrm{dd}, J=15.6,8.1 \mathrm{~Hz}, 1 \mathrm{H}), 4.25-4.22(\mathrm{~d}$ $J=9.7 \mathrm{~Hz}, 1 \mathrm{H}), 3.78-3.69(\mathrm{~m}, 2 \mathrm{H}), 3.57(\mathrm{~s}, 3 \mathrm{H}), 3.54(\mathrm{dd}, J=8.1,4.1 \mathrm{~Hz}, 1 \mathrm{H}), 3.39(\mathrm{~s}, 3 \mathrm{H})$, 3.26 (s, 3H), 3.16-3.13 (m, 1H), 2.58-2.45 (m, 1H), 2.34 (dd, $J=7.5,3.0 \mathrm{~Hz}, 2 \mathrm{H}), 2.15-2.03$ 
$(\mathrm{m}, 1 \mathrm{H}), 1.98-1.84(\mathrm{~m}, 1 \mathrm{H}), 1.83-1.72(\mathrm{~m}, 1 \mathrm{H}), 1.45-1.19(\mathrm{~m}, 6 \mathrm{H}), 1.12(\mathrm{t}, J=7.5 \mathrm{~Hz}, 3 \mathrm{H})$, 1.08-1.03 (m, $21 \mathrm{H}), 1.00(\mathrm{~d}, J=7.0 \mathrm{~Hz}, 3 \mathrm{H}), 0.91(\mathrm{~d}, J=7.5 \mathrm{~Hz}, 3 \mathrm{H}) .{ }^{\mathbf{1 3}} \mathbf{C}$ NMR (125 MHz, $\left.\mathbf{C D C l}_{3}\right):$ 174.1, 171.5, 141.4, 137.2, 128.8, 128.5, 128.1, 126.9, 84.7, 84.0, 80.8, 78.0, 76.2, $60.1,59.1,56.9,40.7,37.8,36.8,33.0,31.1,28.2,26.1,25.9,18.3,16.3,12.6,9.5$. IR $\left(\mathbf{c m}^{-1}\right)$ : 2938, 2865, 1780, 1701, 1465, 1385, 1195, 1111, 1029, 918, 833. MS (ES): $699.4\left(\mathrm{M}+\mathrm{Na}^{+}\right)$. HRMS (ESI): calculated 699.4263, found $699.4258\left(\mathrm{M}+\mathrm{Na}^{+}\right)$.

$[\alpha]_{\mathrm{D}}{ }^{22}-28.6\left(c 0.35, \mathrm{CH}_{2} \mathrm{Cl}_{2}\right)$.

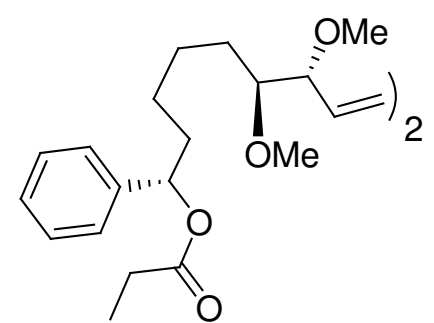

Compound 38: ${ }^{1} \mathbf{H}$ NMR (300 MHz, $\left.\mathbf{C D C l}_{3}\right):$ 7.32-7.27 (m, 10H), $5.71(\mathrm{dd}, J=7.7,6.3 \mathrm{~Hz}, 2 \mathrm{H}), 5.60-5.56(\mathrm{~m}, 2 \mathrm{H}), 3.59-3.55(\mathrm{~m}$, $2 \mathrm{H}), 3.38(\mathrm{~s}, 2 \mathrm{H}), 3.35(\mathrm{~s}, 4 \mathrm{H}), 3.28(\mathrm{~s}, 4 \mathrm{H}), 3.24(\mathrm{~s}, 2 \mathrm{H}), 3.18-3.14$ $(\mathrm{m}, 2 \mathrm{H}), 2.33(\mathrm{dd}, J=7.7,2.6 \mathrm{~Hz}, 4 \mathrm{H}), 1.95-1.82(\mathrm{~m}, 2 \mathrm{H}), 1.81-$ $1.71(\mathrm{~m}, 2 \mathrm{H}), 1.44-1.22(\mathrm{~m}, 12 \mathrm{H}), 1.12(\mathrm{t}, J=7.7 \mathrm{~Hz}, 6 \mathrm{H}) .{ }^{13} \mathrm{C}$ NMR (75 MHz, $\mathbf{C D C l}_{3}$ ): 173.9, 141.0, 132.0, 128.5, 127.9, 126.6, 84.0, 83.4, 75.9, 58.7, 58.6, 56.8, 56.7, 36.5, 30.6, 28.0, 25.7, 25.6,

9.2. MS (ESI): $663.3\left(\mathrm{M}+\mathrm{Na}^{+}\right)$.

*Synthesis of compounds $\mathbf{2 6 , 2 7}$ and $\mathbf{2 8}$.

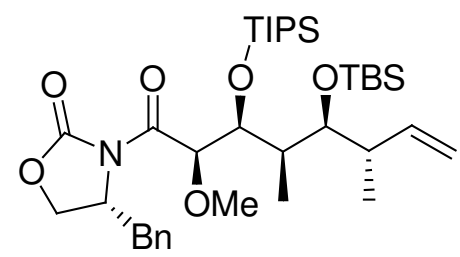

Compound h: The alcohol $\mathbf{1 6}$ was obtained from $1000 \mathrm{mg}(2.0$ mmol) of aldehyde $\mathbf{1 5}$ as described before. To a solution 16 in 5 $\mathrm{mL}$ of $\mathrm{CH}_{2} \mathrm{Cl}_{2}$ were added at $0^{\circ} \mathrm{C}$ : $556 \mu \mathrm{L}$ of $\mathrm{Et}_{3} \mathrm{~N}(4.0 \mathrm{mmol})$ and $460 \mu \mathrm{L}$ of TBS triflate $(2.0 \mathrm{mmol})$. The reaction was stirred 3 hrs at $\mathrm{RT}$ and then diluted with $10 \mathrm{~mL}$ of a saturated aqueous solution of $\mathrm{NaHCO}_{3}$ and $10 \mathrm{~mL}$ of $\mathrm{CH}_{2} \mathrm{Cl}_{2}$. The organic phase was separated and the aqueous phase was extracted with $10 \mathrm{~mL}$ of $\mathrm{CH}_{2} \mathrm{Cl}_{2}$. The combined extracts were dried with $\mathrm{Na}_{2} \mathrm{SO}_{4}$ and concentrated. Silica gel chromatography of the residue (ethyl acetate/ cyclohexane, 1:9) afforded as a pale yellow oil the desired compound $\mathbf{i}(528 \mathrm{mg}, 40 \%$ on 2 steps) without any diasteroisomers. ${ }^{1} \mathbf{H}$ NMR (300 MHz, $\left.\mathbf{C D C l}_{3}\right)$ : 7.37-7.23 (m, 5H), 5.81 (ddd, $J=17.3,10.1$, $7.9 \mathrm{~Hz}, 1 \mathrm{H}), 5.24(\mathrm{~d}, J=7.9 \mathrm{~Hz}, 1 \mathrm{H}), 5.05(\mathrm{dd}, J=17.3,2.6 \mathrm{~Hz}, 1 \mathrm{H}), 4.93(\mathrm{dd}, J=10.1,2.6$ $\mathrm{Hz}, 1 \mathrm{H}), 4.57-4.51(\mathrm{~m}, 1 \mathrm{H}), 4.21-4.13(\mathrm{~m}, 3 \mathrm{H}), 3.62(\mathrm{~d}, J=9.4 \mathrm{~Hz}, 1 \mathrm{H}), 3.45(\mathrm{dd}, \mathrm{J}=13.1$, $3.0 \mathrm{~Hz}, 1 \mathrm{H}), 3.38(\mathrm{~s}, 3 \mathrm{H}), 2.76(\mathrm{dd}, J=13.1,10.1 \mathrm{~Hz}, 1 \mathrm{H}), 2.44-2.34(\mathrm{~m}, 1 \mathrm{H}), 1.38-1.28(\mathrm{~m}$, $1 \mathrm{H}), 1.14-1.10(\mathrm{br}, 21 \mathrm{H}), 1.04(\mathrm{~d}, J=6.8 \mathrm{~Hz}, 3 \mathrm{H}), 0.94(\mathrm{~d}, J=7.1 \mathrm{~Hz}, 3 \mathrm{H}), 0,90(\mathrm{~m}, 9 \mathrm{H})$, 0,06 (s, 6H). ${ }^{13} \mathbf{C}$ NMR (75 MHz, $\left.\mathbf{C D C l}_{3}\right):$ 172.6, 153.0, 140.1, 135.2, 129.3, 129.0, 127.4, $115.2,76.5,66.4,57.1,56.4,41.8,40.2,37.8,26.3,19.8,18.5,13.7,11.3,-3.0,-3.8$. IR $\left(\mathbf{c m}^{-}\right.$ 1): 2930, 2862, 1766, 1707, 1456, 1380, 1180, 1111, 1032, 832, 698. MS (ESI): 684.3 $\left(\mathrm{M}+\mathrm{Na}^{+}\right)$. HRMS (LSIMS): calculated 662.4272, found $662.4277\left(\mathrm{M}+\mathrm{H}^{+}\right) .[\alpha]_{\mathrm{D}}{ }^{22}-37.7(c$ 1.47, $\mathrm{CH}_{2} \mathrm{Cl}_{2}$ ).

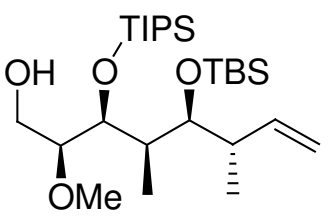

Compound i: To a solution of $267 \mathrm{mg}(0.4 \mathrm{mmol})$ of $\mathbf{h}$ in $2 \mathrm{~mL}$ of THF at $0^{\circ} \mathrm{C}$ were added $1.6 \mathrm{~mL}$ of a $2 \mathrm{M}$ solution of lithium borohydryde in THF $(3.3 \mathrm{mmol})$ and $120 \mu \mathrm{L}(2.8 \mathrm{mmol})$ of methanol. The reaction was stirred $12 \mathrm{hrs}$ at RT and then diluted with $10 \mathrm{~mL}$ of a saturated aqueous solution of $\mathrm{NaHCO}_{3}$ and $10 \mathrm{~mL}$ of $\mathrm{Et}_{2} \mathrm{O}$. The organic phase was separated and the aqueous phase was extracted with $10 \mathrm{~mL}$ of $\mathrm{Et}_{2} \mathrm{O}$. The combined extracts were dried with $\mathrm{Na}_{2} \mathrm{SO}_{4}$ and concentrated. Silica gel chromatography of the residue (ethyl acetate/ cyclohexane, 1:9) afforded as a pale yellow oil the desired compound $\mathbf{i}$ (145 $\mathrm{mg}$, 73\%). ${ }^{1} \mathbf{H}$ NMR (300 $\mathbf{M H z} \mathbf{C D C l}_{3}$ ): 5.91 (ddd, $\left.J=18.1,9.4,8.7 \mathrm{~Hz}, 1 \mathrm{H}\right), 5.04-4.99$ (m, 2H), $4,04(\mathrm{dd}, J=7.2,1.9 \mathrm{~Hz}, 1 \mathrm{H}), 3.88-3.82(\mathrm{~m}, 1 \mathrm{H}), 3.70(\mathrm{dd}, J=8.7,1.5 \mathrm{~Hz}, 1 \mathrm{H}), 3.59-3.52$ 
(m, 1H), $3.41(\mathrm{~s}, 3 \mathrm{H}), 3.24(\mathrm{p}, J=3.7 \mathrm{~Hz}, 1 \mathrm{H}), 2.49-2.40(\mathrm{~m}, 1 \mathrm{H}), 1.81-1.70(\mathrm{~m}, 2 \mathrm{H}), 1.12-$ 1.10 (br, 21H), 1.05 (d, $J=7.2 \mathrm{~Hz}, 3 \mathrm{H}), 0.92-0.89$ (br, 9H), 0.89 (d, $J=6.8 \mathrm{~Hz}, 3 \mathrm{H}), 0,06$ (s, 6H). ${ }^{13}$ C NMR (75 MHz, $\left.\mathbf{C D C l}_{3}\right)$ : 140.4, 115.1, 84.7, 76.8, 72.2, 59.6, 57.1, 41.8, 39.1, 26.3, 19.2, 18.5, 13.5, 11.1, -3.1, -3.7. IR $\left(\mathbf{c m}^{-1}\right): 2927,2863,1463,1253,1034,835,773 . \mathbf{M S}$ (CI): $489\left(\mathrm{M}+\mathrm{H}^{+}\right)$. HRMS (CI): calculated 489.3795, found $489.3794\left(\mathrm{M}+\mathrm{H}^{+}\right) \cdot[\alpha]_{\mathrm{D}}{ }^{22}=+6,8$ (c $=0.995, \mathrm{CH}_{2} \mathrm{Cl}_{2}$ ).

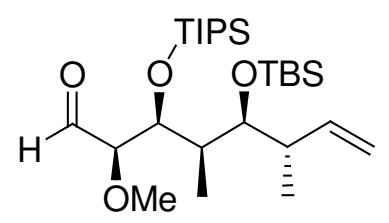

Compound $\mathbf{j}$ : To a solution of $113 \mathrm{mg}$ of $\mathbf{i}(0.23 \mathrm{mmol})$ in $1 \mathrm{~mL}$ of $\mathrm{CH}_{2} \mathrm{Cl}_{2}$ were added $0.95 \mathrm{~mL}$ of a $0.5 \mathrm{M}$ solution of Dess-Martin periodinane $(0.47 \mathrm{mmol})$. The reaction was stirred $2 \mathrm{hrs}$ and diluted with $2 \mathrm{~mL}$ of a saturated aqueous solution of $\mathrm{Na}_{2} \mathrm{~S}_{2} \mathrm{O}_{3}, 2 \mathrm{~mL}$ of a saturated aqueous solution of $\mathrm{NaHCO}_{3}$ and $4 \mathrm{ml}$ of $\mathrm{CH}_{2} \mathrm{Cl}_{2}$. The organic phase was separated and the aqueous phase was extracted with $4 \mathrm{~mL}$ of $\mathrm{CH}_{2} \mathrm{Cl}_{2}$. The combined extracts were dried with $\mathrm{Na}_{2} \mathrm{SO}_{4}$ and concentrated. Silica gel chromatography of the residue (ethyl acetate/ cyclohexane, 1:9) afforded as a colorless oil the desired compound $\mathbf{j}$ (73 mg, 65\%). ${ }^{1} \mathbf{H}$ NMR (300 MHz, $\left.\mathbf{C D C l}_{3}\right): 9.56(\mathrm{~d}, J=3.4 \mathrm{~Hz}, 1 \mathrm{H}), 5.83(\mathrm{ddd}, J=18.6$, $10.4,8.8 \mathrm{~Hz}, 1 \mathrm{H}), 5.05-4.89$ (m, 2H), 4.17 (dd, $J=7.4,2.8 \mathrm{~Hz}, 1 \mathrm{H}), 3.69$ (dd, $J=8.1,2.6 \mathrm{~Hz}$, $1 \mathrm{H}), 3.61(\mathrm{dd}, J=7.2,3.2 \mathrm{~Hz}, 1 \mathrm{H}), 3.34(\mathrm{~s}, 3 \mathrm{H}), 2.46-2.34(\mathrm{~m}, 1 \mathrm{H}), 1.65-1.57(\mathrm{~m}, 1 \mathrm{H}), 1.13-$ $1.07(\mathrm{br}, 21 \mathrm{H}), 1.02(\mathrm{~d}, J=7.0 \mathrm{~Hz}, 3 \mathrm{H}), 0.94(\mathrm{~d}, J=6.8 \mathrm{~Hz}, 3 \mathrm{H}), 0.90(\mathrm{~m}, 9 \mathrm{H}), 0.05(\mathrm{~s}$, 6H). ${ }^{13}$ C NMR (75 MHz, $\mathbf{C D C l}_{3}$ ): 201.4, 140.3, 115.0, 89.3, 75.9, 72.6, 57.9, 42.1, 39.9, 26.3, 18.9, 18.4, 13.4, 10.9, -3.1, -3.5. MS (CI): $487\left(\mathrm{M}+\mathrm{H}^{+}\right)$. HRMS (CI): calculated 487.3630, found $487.3636\left(\mathrm{M}+\mathrm{H}^{+}\right) \cdot[\alpha]_{\mathrm{D}}{ }^{22}+22.6\left(c 0.87, \mathrm{CH}_{2} \mathrm{Cl}_{2}\right)$.

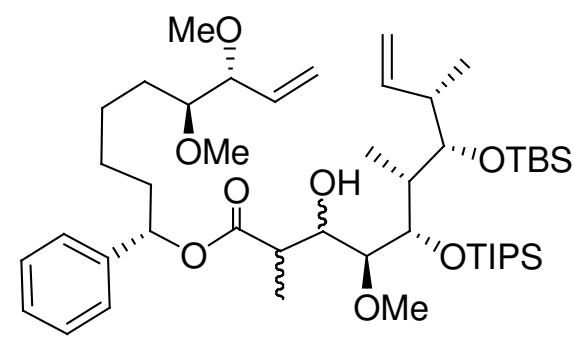

Compound 26: To a solution of $55 \mathrm{mg}$ of ester $2(0.164$ $\mathrm{mmol}$ ) in $0.5 \mathrm{~mL}$ of $\mathrm{THF}$ at $-78^{\circ} \mathrm{C}$ were added dropwise $102 \mu \mathrm{L}$ of a $2 \mathrm{M}$ solution of LDA $(0.205 \mathrm{mmol})$ in THF. The reaction was stirred $35 \mathrm{~min}$ at $-78^{\circ} \mathrm{C}$ and $40 \mathrm{mg}$ of aldehyde $\mathbf{j}(0.082 \mathrm{mmol})$ in $0.3 \mathrm{~mL}$ of THF were added dropwise and the reaction was stirred $4 \mathrm{hrs}$ at $-78^{\circ} \mathrm{C}$. The mixture was diluted with $3 \mathrm{~mL}$ of a saturated aqueous solution of $\mathrm{NaHCO}_{3}$ and $3 \mathrm{~mL}$ of EtOAc. The organic phase was separated and the aqueous phase was extracted with $3 \mathrm{~mL}$ of EtOAc. The combined extracts were dried with $\mathrm{Na}_{2} \mathrm{SO}_{4}$ and concentrated. Silica gel chromatography of the residue (ethyl acetate/ cyclohexane, 1:9) afforded as a colorless oil a 3:1 mixture of 2 diastereoisomers of the desired compound $\mathbf{2 6}$ (47 $\mathrm{mg}, 70 \%) .{ }^{1} \mathbf{H}$ NMR (500 MHz, $\left.\mathbf{C D C l}_{3}\right):$ 7.33-7.26 (m, 5H), 5.98-5.83 (m, 1H), 5.79-5.67 $(\mathrm{m}, 2 \mathrm{H}), 5.30-5.20(\mathrm{~m}, 2 \mathrm{H}), 5.06-4.99(\mathrm{~m}, 2 \mathrm{H}), 4.12-4.02(\mathrm{~m}, 1 \mathrm{H}), 3.70-3.52(\mathrm{~m}, 3 \mathrm{H}), 3.46(\mathrm{~s}$, $1 \mathrm{H}), 3.40-3.37$ (br, 5H), $3.28(\mathrm{~s}, 3 \mathrm{H}), 3.16-3.13(\mathrm{~m}, 1 \mathrm{H}), 3.07(\mathrm{~d}, J=8.1 \mathrm{~Hz}, 0,75 \mathrm{H}), 2.98$ (d, $J=8.6 \mathrm{~Hz}, 0.25 \mathrm{H}), 2.71-2.59(\mathrm{~m}, 2 \mathrm{H}), 2.47-2.41(\mathrm{~m}, 0.75 \mathrm{H}), 2.24(\mathrm{~m}, 0.25 \mathrm{H}), 1.96-1.89(\mathrm{~m}$, $1 \mathrm{H}), 1.82-1.77(\mathrm{~m}, 1 \mathrm{H}), 1.74-1.65(\mathrm{~m}, 1 \mathrm{H}), 1.45-1.17(\mathrm{~m}, 6 \mathrm{H}), 1.14-1.09$ (br, 21H), 1.05 (d, $J$ $=7.2 \mathrm{~Hz}, 3 \mathrm{H}), 0.94-0.90(\mathrm{~m}, 14.25 \mathrm{H}), 0.78(\mathrm{~d}, \mathrm{~J}=6.8 \mathrm{~Hz}, 0.75 \mathrm{H}), 0.07(\mathrm{~s}, 6 \mathrm{H}) .{ }^{13} \mathbf{C ~ N M R}$ (125 MHz, CDCl $\left._{3}\right): 174.7,174.3,140.9,140.5,135.6,128.9,128.8,128.3,126.9,119.3$, $115.9,115.7,85.0,83.8,82.5,77.7,76.6,76.4,72.5,72.4,61.2,58.8,57.1,45.5,42.2,40.3$, $40.2,36.6,30.6,26.8,25.9,20.1,19.1,18.9,18.7,15.0,14.4,14.3,11.5,-2.5,-3.2$. IR $\left(\mathbf{c m}^{-1}\right)$ : 2929, 2862, 1732, 1461, 1252, 1173, 1082, 1031, 638. MS (ESI): $843.5\left(\mathrm{M}+\mathrm{Na}^{+}\right)$. HRMS (LSIMS): calculated 843.5602, found $843.5609\left(\mathrm{M}+\mathrm{Na}^{+}\right)$. 


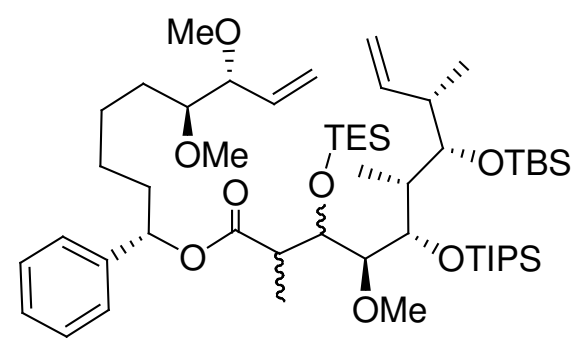

Compound 27: To a solution of $30 \mathrm{mg}$ of $26(0.036$ $\mathrm{mmol}$ ) in $0.8 \mathrm{~mL}$ of $\mathrm{CH}_{2} \mathrm{Cl}_{2}$ were added at $0^{\circ} \mathrm{C}, 20 \mu \mathrm{L}$ of $\mathrm{Et}_{3} \mathrm{~N}(0.14 \mathrm{mmol})$ and $16 \mu \mathrm{L}$ of TES triflate $(0.073 \mathrm{mmol})$. The reaction was stirred $3 \mathrm{hrs}$ at $\mathrm{RT}$ and diluted with $3 \mathrm{~mL}$ of a saturated aqueous solution of $\mathrm{NaHCO}_{3}$ and $4 \mathrm{~mL}$ of EtOAc. The organic phase was separated and the aqueous phase was extracted with $4 \mathrm{~mL}$ of EtOAc. The combined extracts were dried with $\mathrm{Na}_{2} \mathrm{SO}_{4}$ and concentrated. Silica gel chromatography of the residue (ethyl acetate/ cyclohexane, 1:9) afforded as a colorless oil a 3:1 mixture of 2 diastereoisomers of the desired compound 27 (25 mg, 73\%). ${ }^{1} \mathbf{H}$ NMR (500 $\left.\mathbf{~ M H z , ~ C D C l}\right)$ : 7.31-7.25 (m, 5H), 6.19-5.96 (m, 1H), 5.79-5.60 (m, 2H), $5.29(\mathrm{~d}, J=10.6 \mathrm{~Hz}, 1 \mathrm{H}), 5.23(\mathrm{~d}, J$ $=17.3 \mathrm{~Hz}, 1 \mathrm{H}), 5.12-4.98(\mathrm{~m}, 2 \mathrm{H}), 4.23-3.93(\mathrm{~m}, 2 \mathrm{H}), 3.71-3.66(\mathrm{~m}, 1 \mathrm{H}), 3.54(\mathrm{dt}, J=3.7,7.5$ $\mathrm{Hz}, 1 \mathrm{H}), 3.79-3.71(\mathrm{~m}, 3 \mathrm{H}), 3.31-3.31(\mathrm{~m}, 6 \mathrm{H}), 3.15-3.11(\mathrm{~m}, 1 \mathrm{H}), 2.93(\mathrm{~s}, 1 \mathrm{H}), 2.91(\mathrm{t}, J=$ $7.3 \mathrm{~Hz}, 0.75 \mathrm{H}), 2,77(\mathrm{t}, J=7.3 \mathrm{~Hz}, 0.25 \mathrm{H}), 2.62(\mathrm{t}, J=7.2 \mathrm{~Hz}, 0.25), 2.53(\mathrm{t}, J=7.2 \mathrm{~Hz}$, $0.75 \mathrm{H}), 1.98-1.85(\mathrm{~m}, 1 \mathrm{H}), 1.81-1.71(\mathrm{~m}, 1 \mathrm{H}), 1.44-1.41(\mathrm{~m}, 2 \mathrm{H}), 1.38-1.25(\mathrm{~m}, 2 \mathrm{H}), 1.19(\mathrm{~d}$, $J=6.8 \mathrm{~Hz}, 2 \mathrm{H}), 1.12-1.01(\mathrm{~m}, 27 \mathrm{H}), 0.97-0.88(\mathrm{~m}, 16 \mathrm{H}), 0.77(\mathrm{t}, \mathrm{J}=7.9 \mathrm{~Hz}, 6 \mathrm{H}), 0.64-0.55$ $(\mathrm{m}, 1.5 \mathrm{H}), 0.50-0.31(\mathrm{~m}, 4.5 \mathrm{H}), 0.06(\mathrm{~s}, 6 \mathrm{H}) .{ }^{13} \mathbf{C}$ NMR (125 MHz, CDCl $)$ : 174.5, 141.0, $140.7,140.5,135.6,128.7,128.6,128.2$, 128.0, 127.3, 127.1, 119.3, 115.6, 85.0, 83.8, 78.4, 77.9, 76.5, 75.9, 58.8, 57.8, 57.1, 43.8, 41.1, 40.0, 37.1, 36.3, 30.7, 26.7, 25.9, 21.2, 20.8, $19.1,19.0,15.1,14.5,14.3,12.6,7.3,5.3,5.1,-2.5,-2.6,-3.0,-3.1 . \mathbf{I R}\left(\mathbf{c m}^{-1}\right): 2932,2863$, 1732, 1460, 1252, 1089, 1044, 834. MS (ESI): $957.5\left(\mathrm{M}+\mathrm{Na}^{+}, 100 \%\right)$. HRMS (CI): calculated 957.6467 , found $957.6465\left(\mathrm{M}+\mathrm{Na}^{+}\right)$.

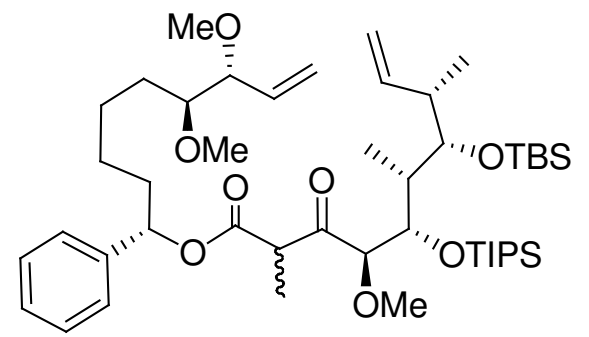

Compound 28: To a solution of $38 \mathrm{mg}$ of $\mathbf{2 6}(0.046$ $\mathrm{mmol}$ ) in $1 \mathrm{~mL}$ of $\mathrm{CH}_{2} \mathrm{Cl}_{2}$ were added $0.3 \mathrm{~mL}$ of a $0.5 \mathrm{M}$ solution of Dess-Martin periodinane $(0.15 \mathrm{mmol})$ in $\mathrm{CH}_{2} \mathrm{Cl}_{2}$. The reaction was stirred $2 \mathrm{hrs}$ at $\mathrm{RT}$ and and diluted with $2 \mathrm{~mL}$ of a saturated aqueous solution of $\mathrm{Na}_{2} \mathrm{~S}_{2} \mathrm{O}_{3}, 2 \mathrm{~mL}$ of a saturated aqueous solution of $\mathrm{NaHCO}_{3}$ and $4 \mathrm{ml}$ of $\mathrm{CH}_{2} \mathrm{Cl}_{2}$. The organic phase was separated and the aqueous phase was extracted with $4 \mathrm{~mL}$ of $\mathrm{CH}_{2} \mathrm{Cl}_{2}$. The combined extracts were dried with $\mathrm{Na}_{2} \mathrm{SO}_{4}$ and concentrated. Silica gel chromatography of the residue (ethyl acetate/ cyclohexane, 1:9) afforded as a colorless oil a 3:2 mixture of 2 diastereoisomers of the desired compound 28 (27 mg, 72\%). ${ }^{1} \mathbf{H}$ NMR (500 MHz, $\left.\mathbf{C D C l}_{3}\right)$ : 7.35-7.26 (m, 5H), 5.93-5.70 (m, $3 \mathrm{H}), 5.31-5.22(\mathrm{~m}, 2 \mathrm{H}), 5.05-4.72(\mathrm{~m}, 2 \mathrm{H}), 4.17-4.15(\mathrm{~m}, 0.6 \mathrm{H}), 4.05(\mathrm{~d}, J=5.6 \mathrm{~Hz}, 0.4 \mathrm{H})$, $3.97(\mathrm{~m}, 0.6 \mathrm{H}), 3.86(\mathrm{q}, J=7.2 \mathrm{~Hz}, 0.4 \mathrm{H}), 3.76(\mathrm{dd}, J=6.6,2.8 \mathrm{~Hz}, 0.4 \mathrm{H}), 3.69-3.61(\mathrm{~m}$, 1.6H), 3.56-3.54 (m, 1H), $3.38(\mathrm{~s}, 3 \mathrm{H}), 3.28(\mathrm{~s}, 3 \mathrm{H}), 3.21(\mathrm{~s}, 1 \mathrm{H}), 3.16-3.13(\mathrm{~m}, 1 \mathrm{H}), 3.07$ (s, $1 \mathrm{H}), 2.94(\mathrm{~s}, 1 \mathrm{H}), 2.51-2.44(\mathrm{~m}, 0.3 \mathrm{H}), 2.37-2.32(\mathrm{~m}, 0.3 \mathrm{H}), 2.28-2.22(\mathrm{~m}, 0.4 \mathrm{H}), 1.99-1.89$ $(\mathrm{m}, 1 \mathrm{H}), 1.86-1.73(\mathrm{~m}, 1 \mathrm{H}), 1.47-1.21(\mathrm{~m}, 9 \mathrm{H}), 1.12-1.01(\mathrm{~m}, 23.2 \mathrm{H}), 0.97(\mathrm{t}, J=6.6 \mathrm{~Hz}$, 1.8H), 0.91-0.89 (m, 12H), 0.05-0.04 (m, 6H). ${ }^{13} \mathbf{C}$ NMR (125 MHz, CDCl $\mathbf{~ M}_{3}$ : 175.6, 169.5, $141.0,140.4$, 135.6, 128.9, 128.8, 127.2, 127.1, 126.8, 119.3, 115.4, 91.9, 90.0, 85.0, 83.8, $77.8,77.6,76.8,75.6,75.4,58.9,57.5,57.1,56.3,51.9,42.8,41.8,41.0,30.6,26.7,25.9$, $19.1,19.0,18.9,18.8,14.2,14.0,13.8,11.6,10.9,-2.6,-3.5 . \mathbf{I R}\left(\mathbf{c m}^{-1}\right): 2914,2848,1699$, 1471, 1299, 1109, 1035, 882. MS (ESI): $841.4\left(\mathrm{M}+\mathrm{Na}^{+}\right)$. HRMS (LSIMS): calculated 841.5446, found $841.5444\left(\mathrm{M}+\mathrm{Na}^{+}\right)$. 


\section{HARDCOPY ${ }^{1} \mathrm{H}$ and ${ }^{13} \mathrm{C}$ NMR SPECTRA}

\section{Index}

\begin{tabular}{|c|c|}
\hline Spectra of & page \\
\hline compound 6 & 17 \\
\hline compound 7 & 20 \\
\hline compound $\mathbf{8}$ & 23 \\
\hline compound 9 & 26 \\
\hline compound 2 & 29 \\
\hline Mosher esters - determination of C-17 abs. config. & 32 \\
\hline Mosher esters - determination of C-11 / C-12 abs. config. & 36 \\
\hline Acetonide - determination of C-11 / C-12 rel. config. & 39 \\
\hline compound 13 & 42 \\
\hline compound 14 & 43 \\
\hline lactone - determination of the rel. config. of $\mathbf{1 4}$ & 46 \\
\hline compound 15 & 47 \\
\hline compound 36 & 49 \\
\hline compound $\mathbf{1 7}$ & 52 \\
\hline compound 18 & 58 \\
\hline compound 21 & 61 \\
\hline compound 22 & 64 \\
\hline compound $\mathbf{2 3}$ & 65 \\
\hline compound $\mathbf{3 7}$ & 66 \\
\hline compound 38 & 69 \\
\hline intermediates for compounds $\mathbf{2 6}-\mathbf{2 8}$ & 72 \\
\hline compound 26 & 81 \\
\hline compound 27 & 84 \\
\hline compound 28 & 87 \\
\hline
\end{tabular}




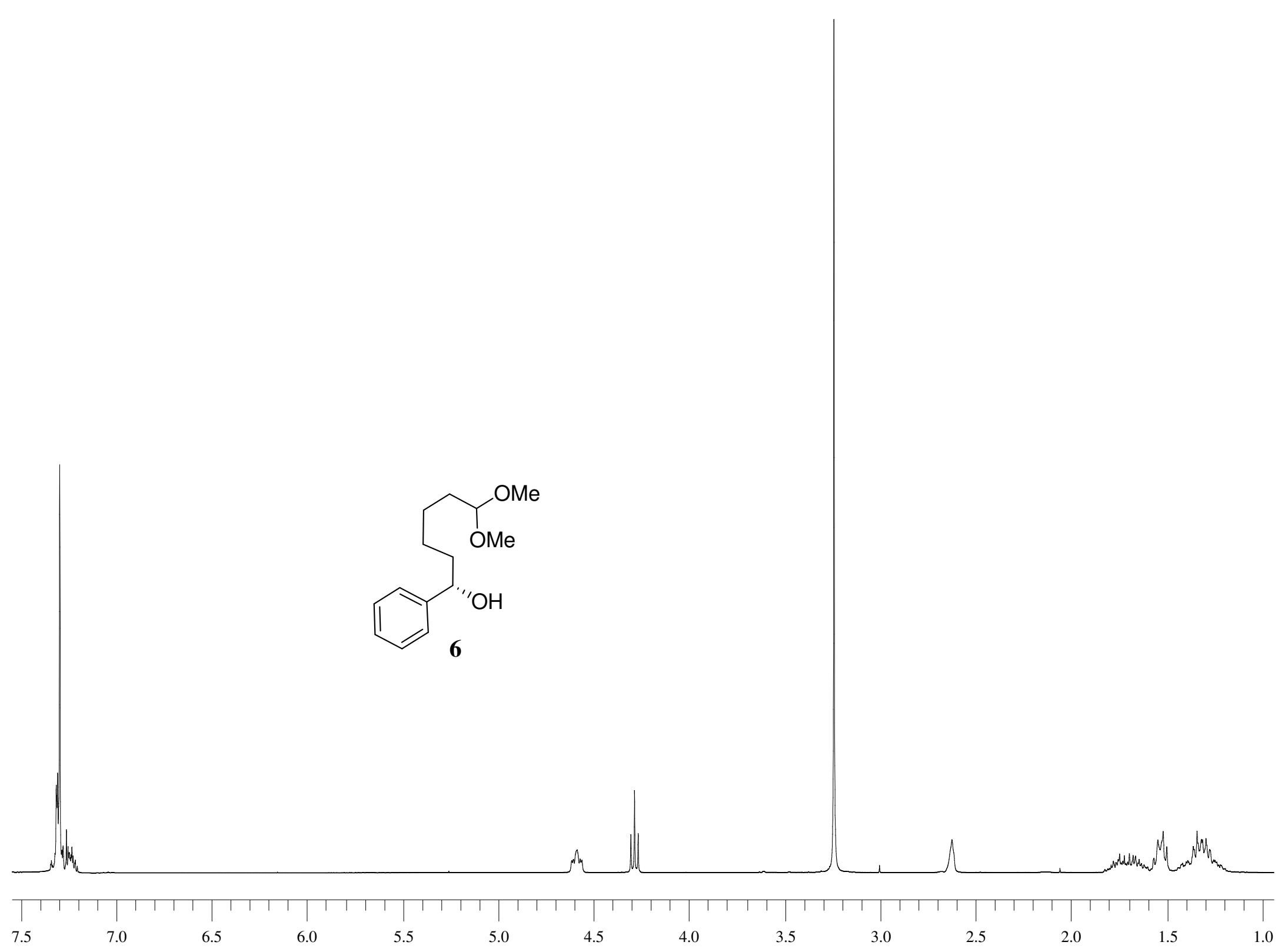


Ciufolini et al.

Studies toward Soraphen A

S 18

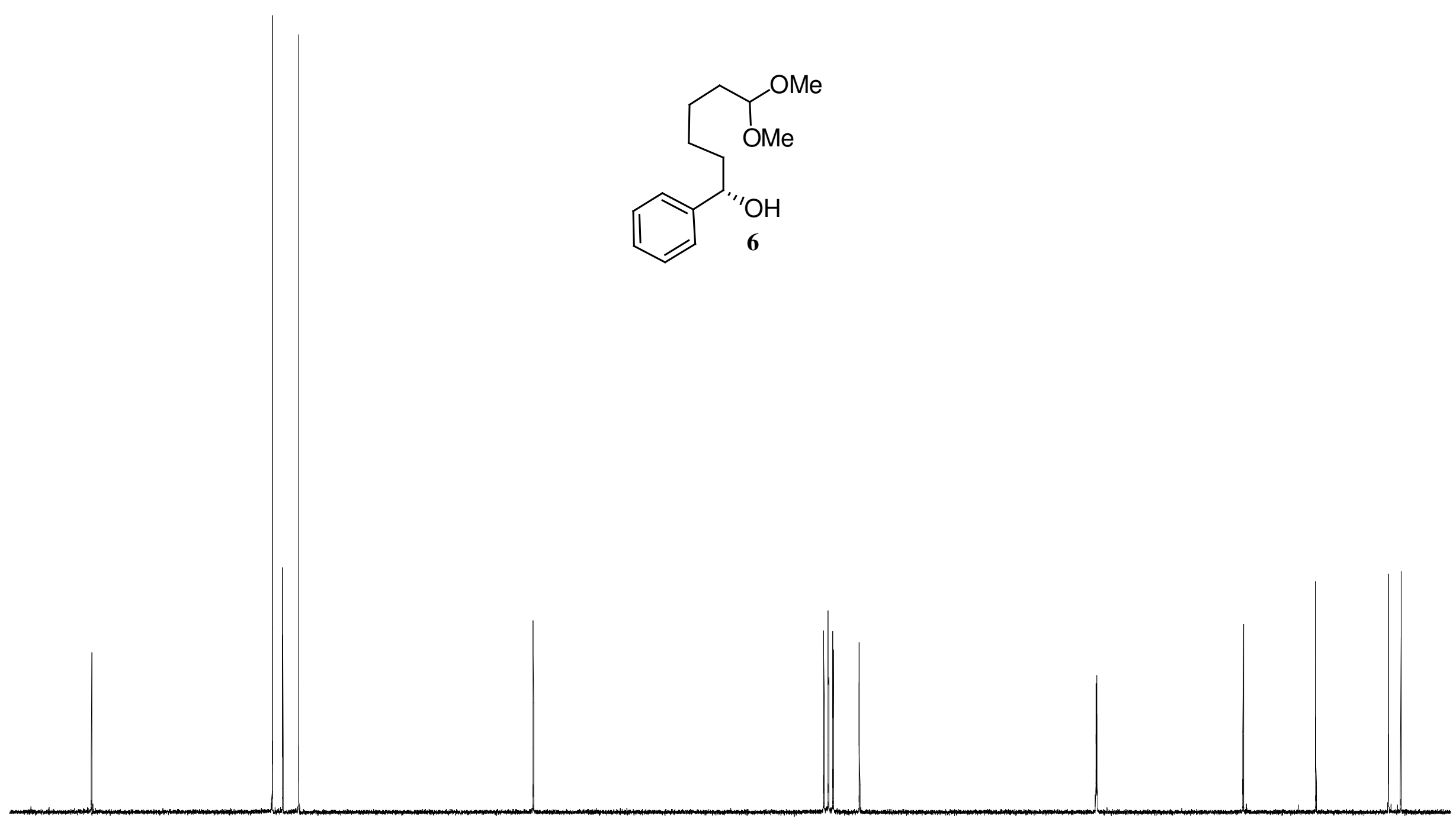

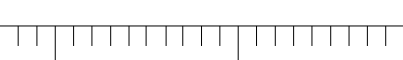

140

130

120

110

100
90

80 


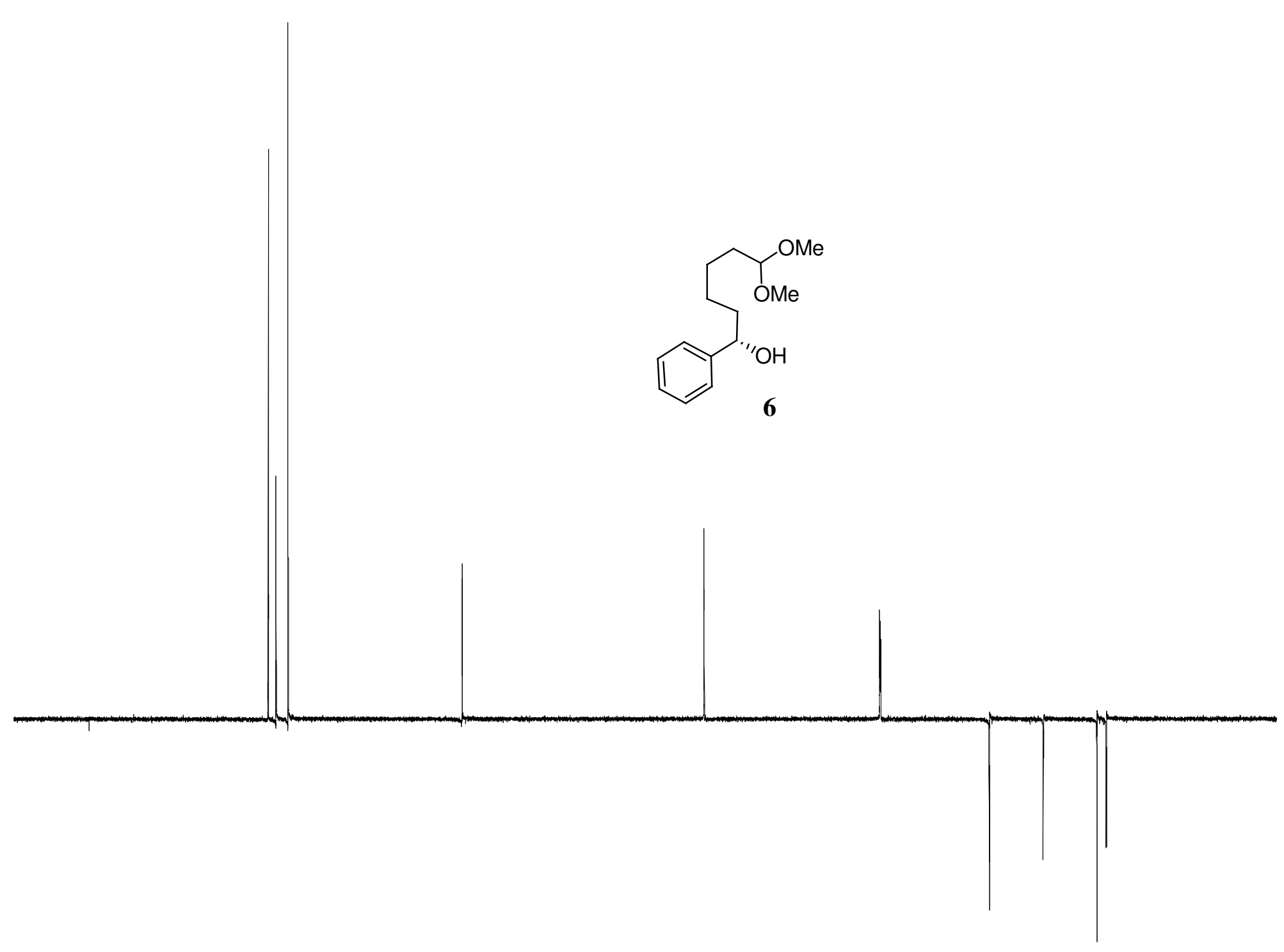




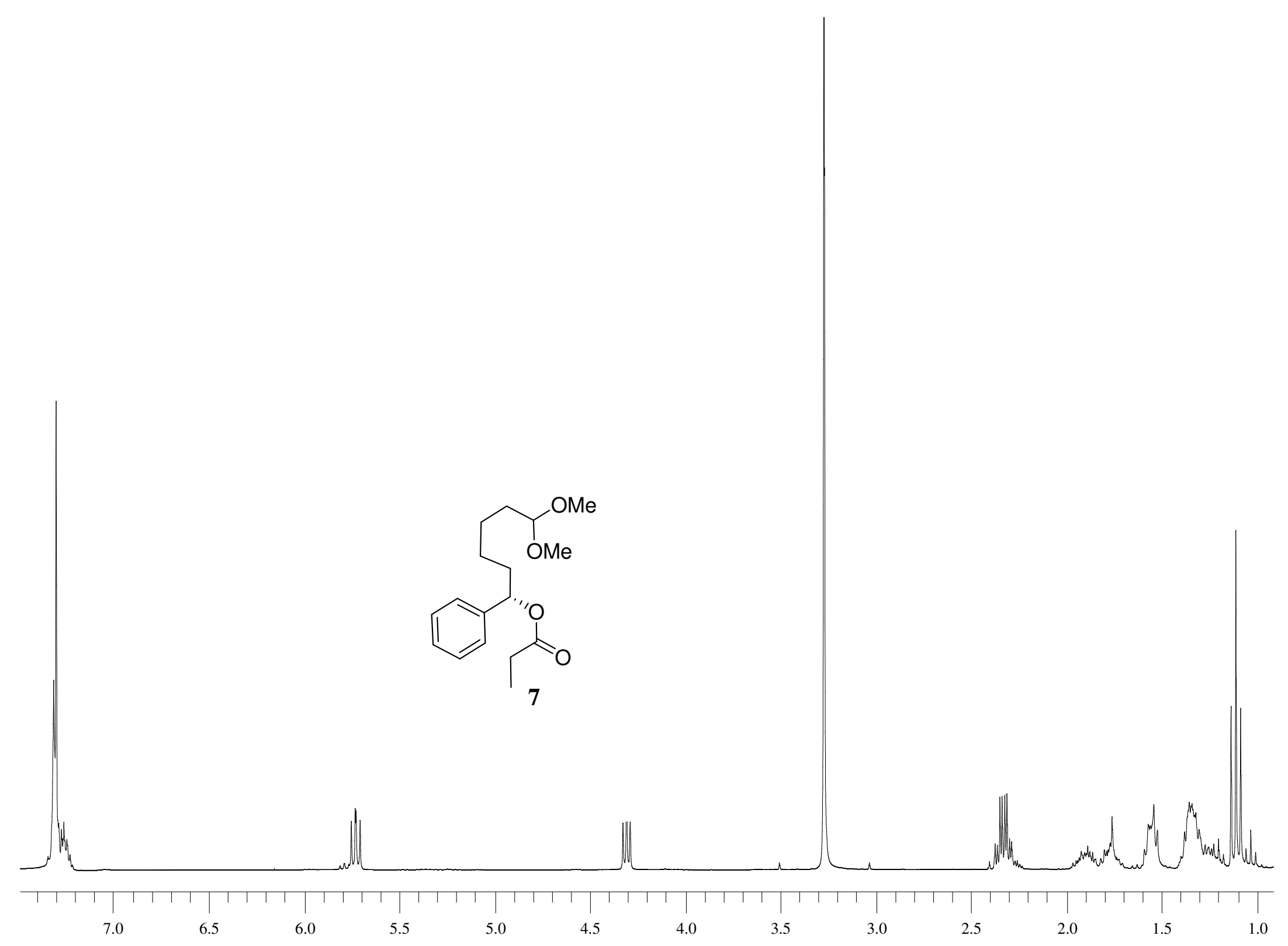




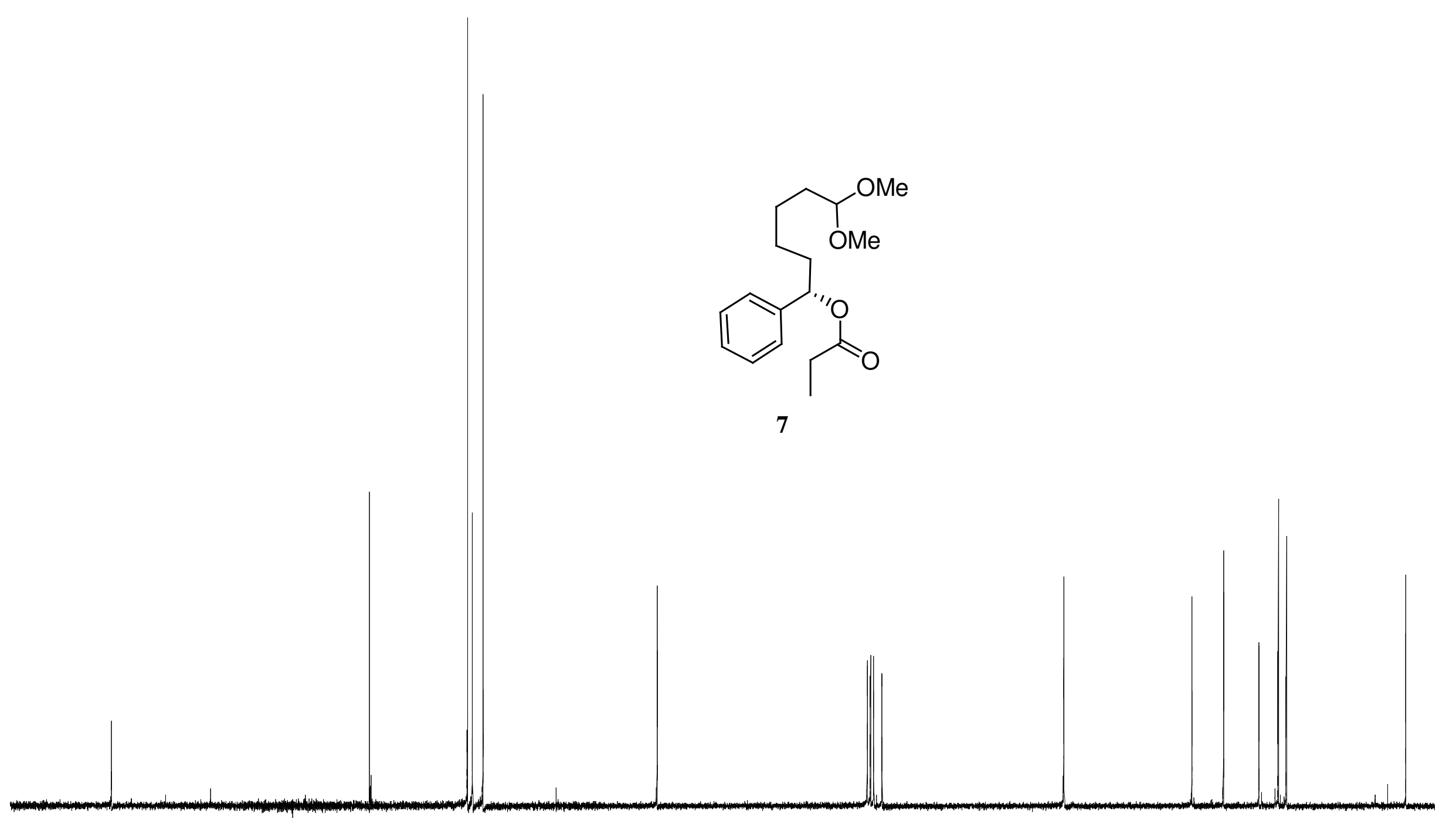

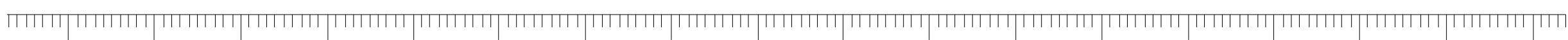
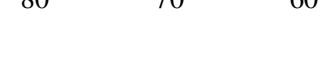


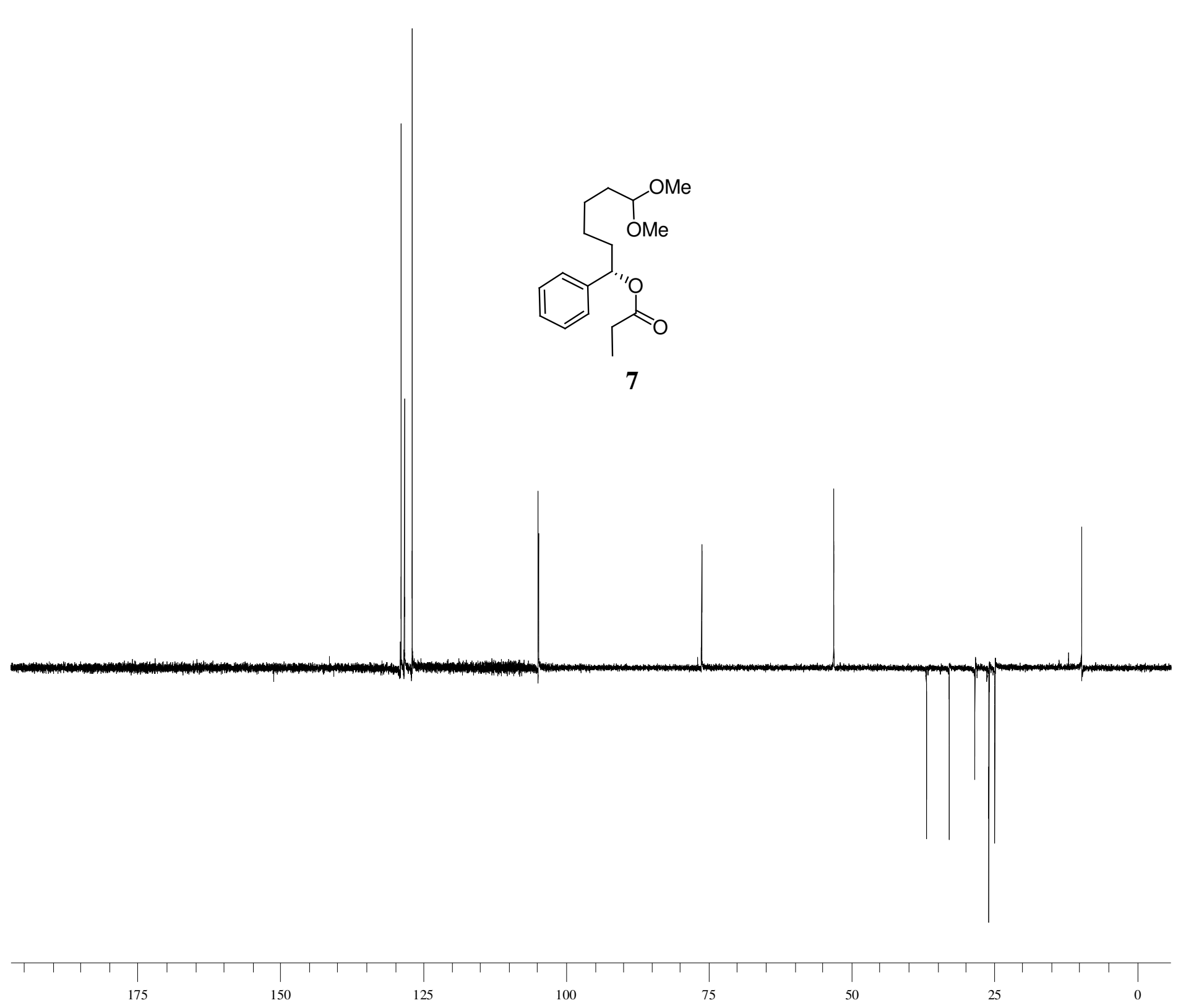



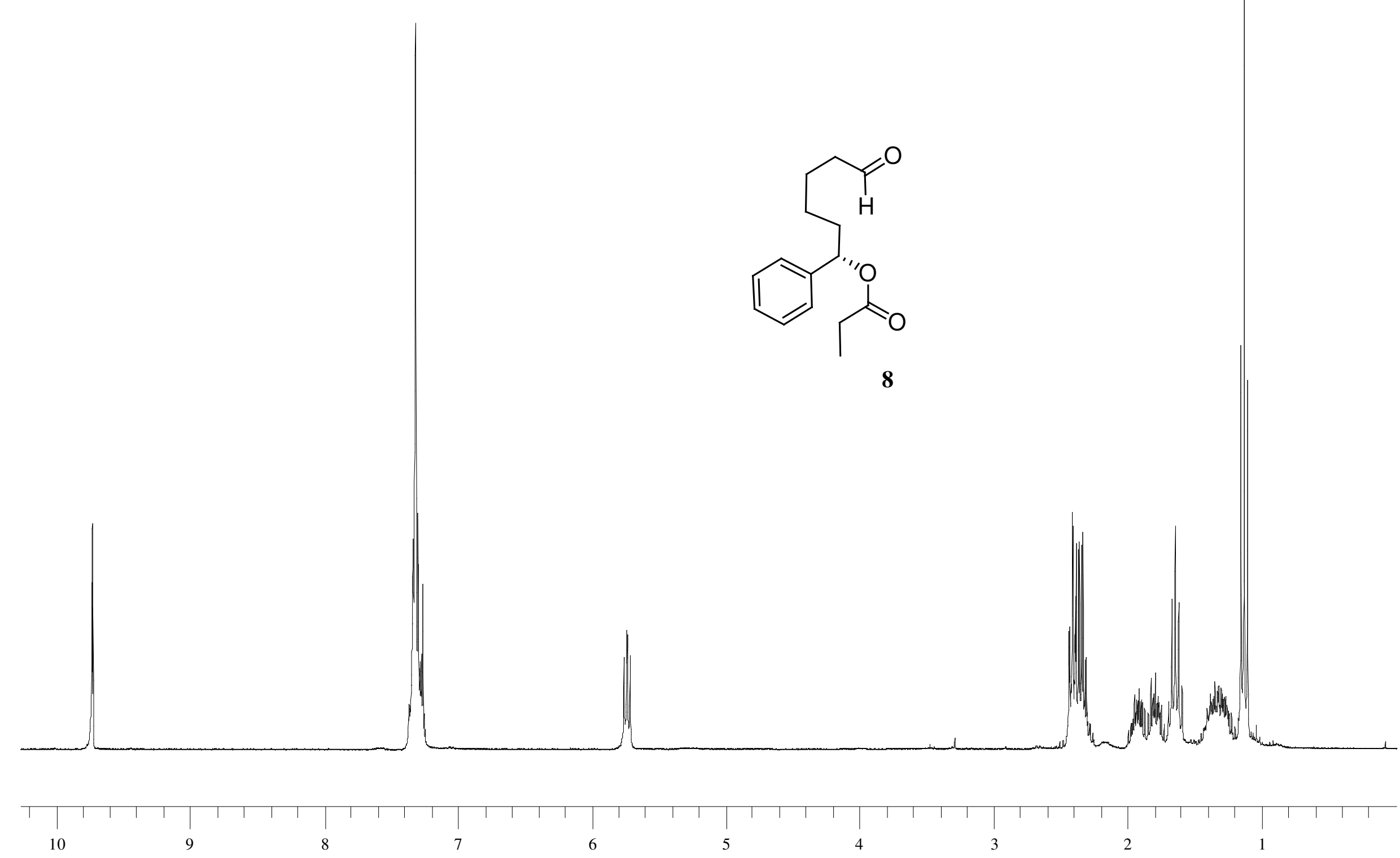


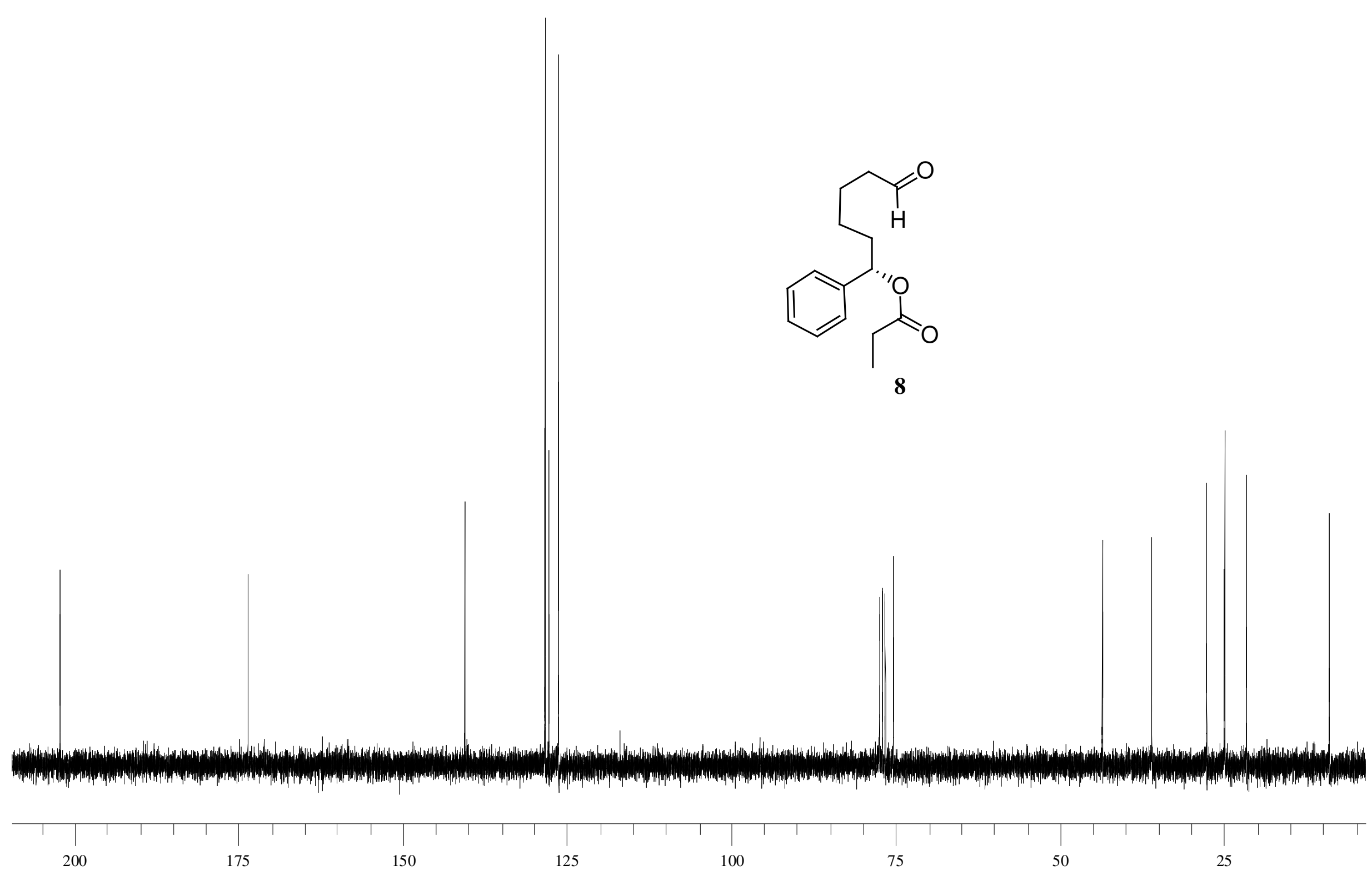




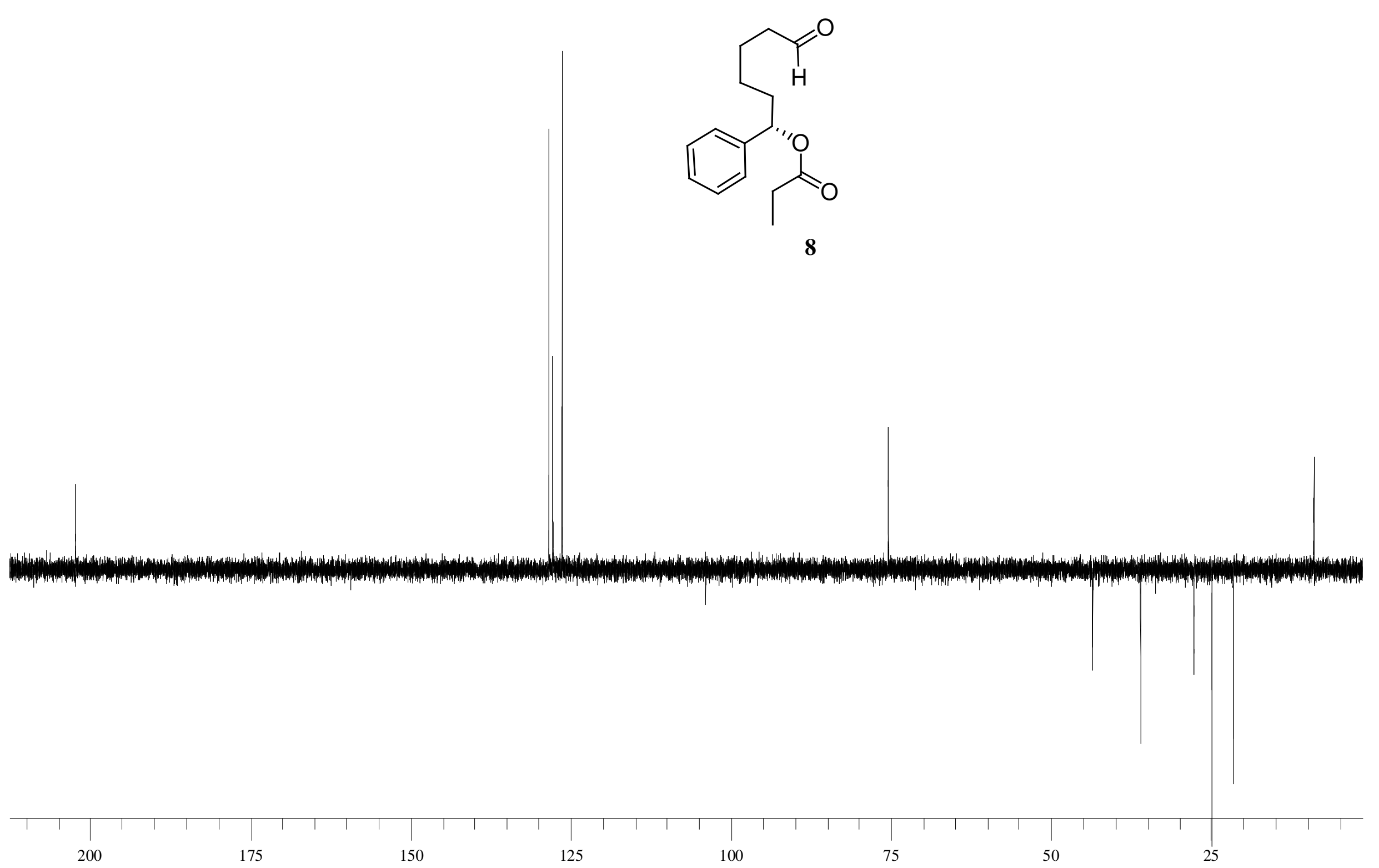




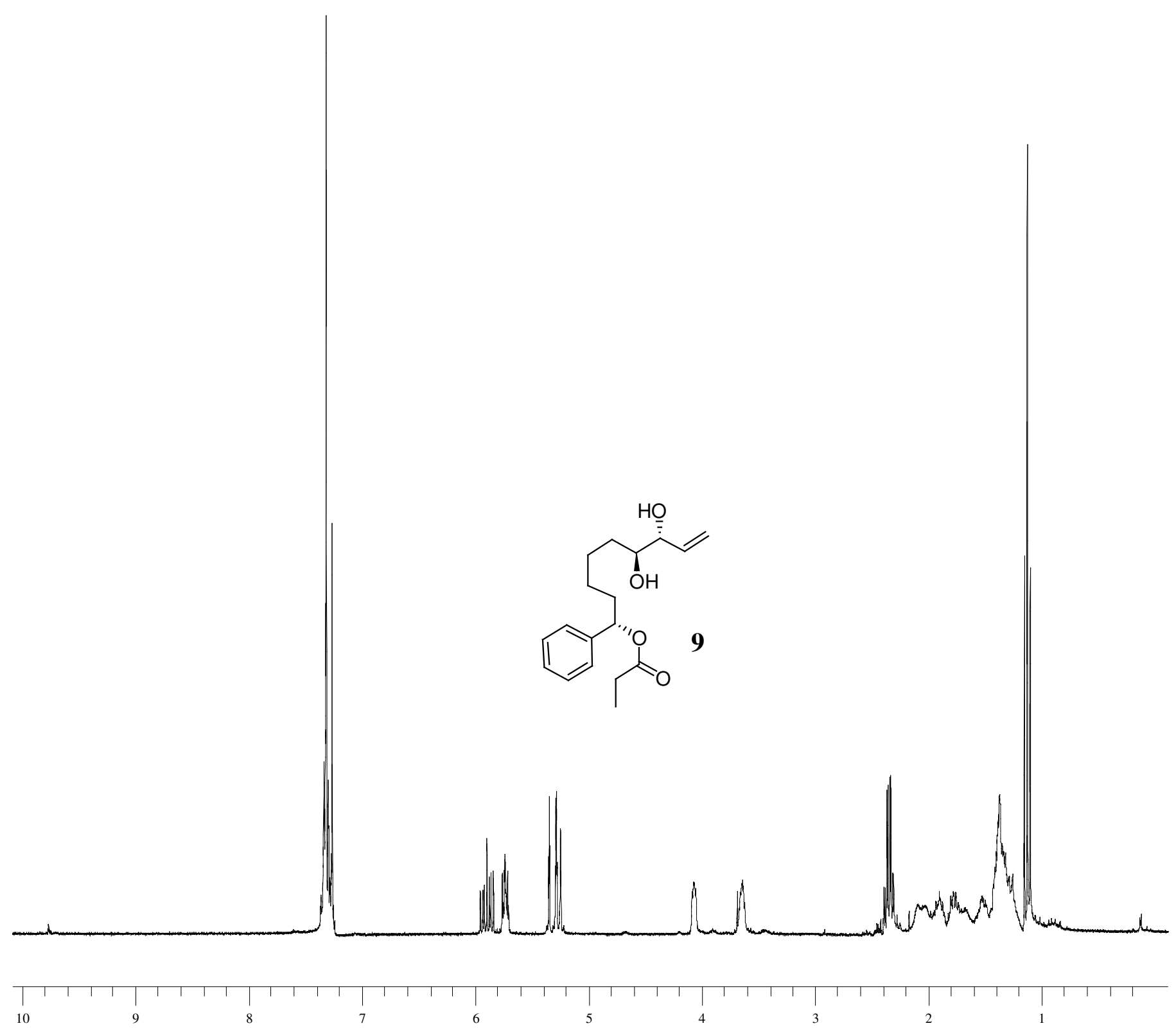




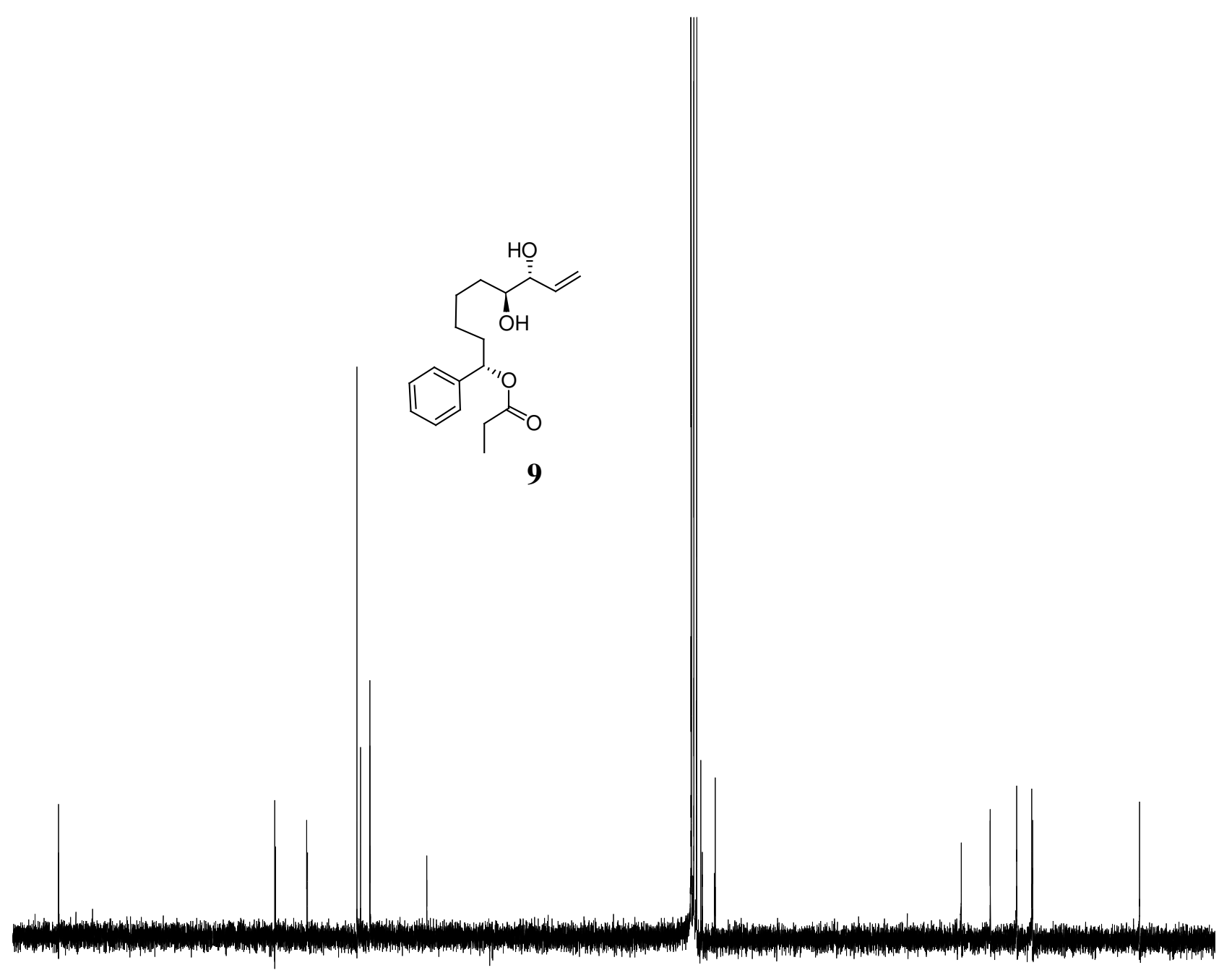




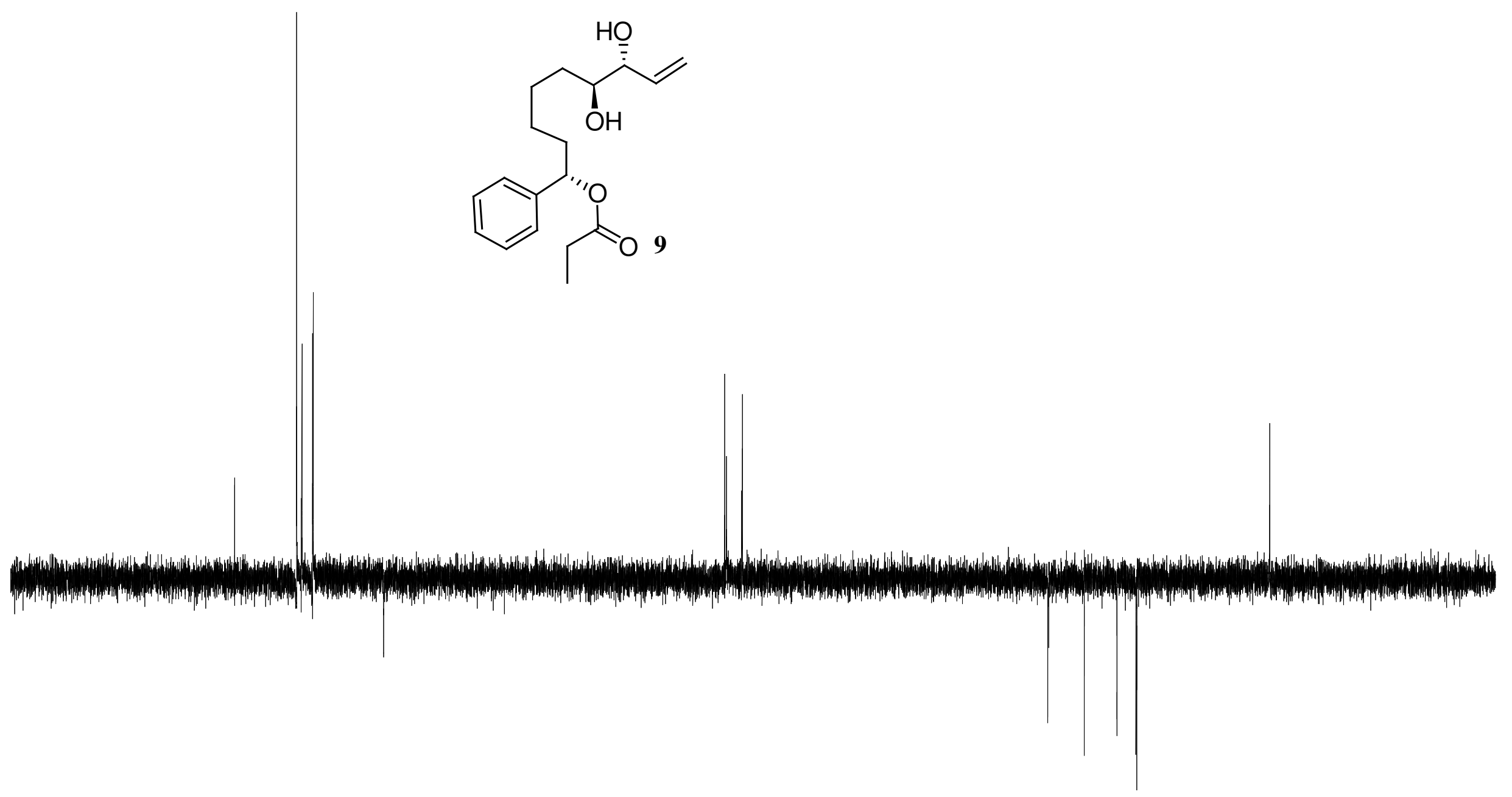

80 


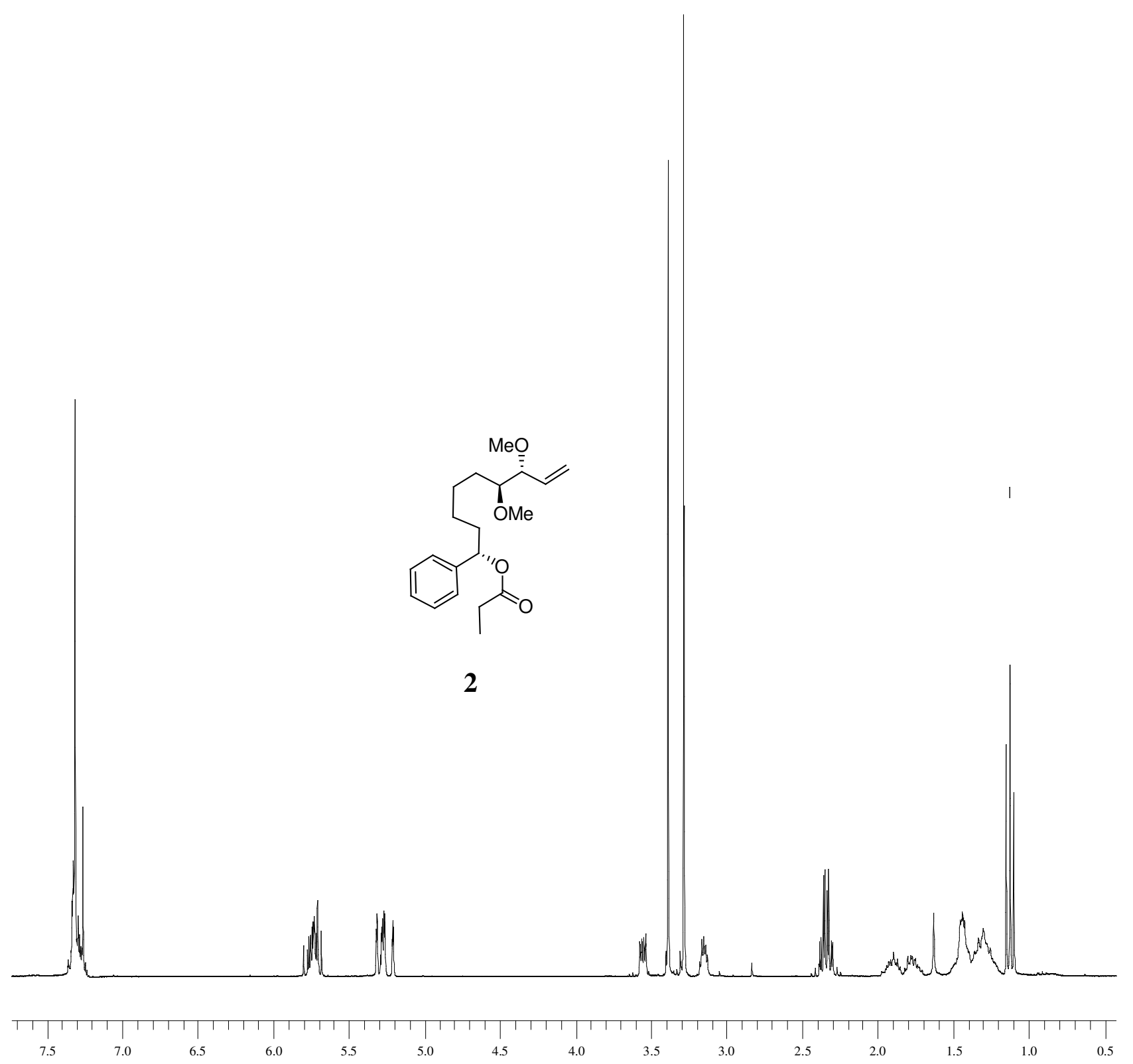



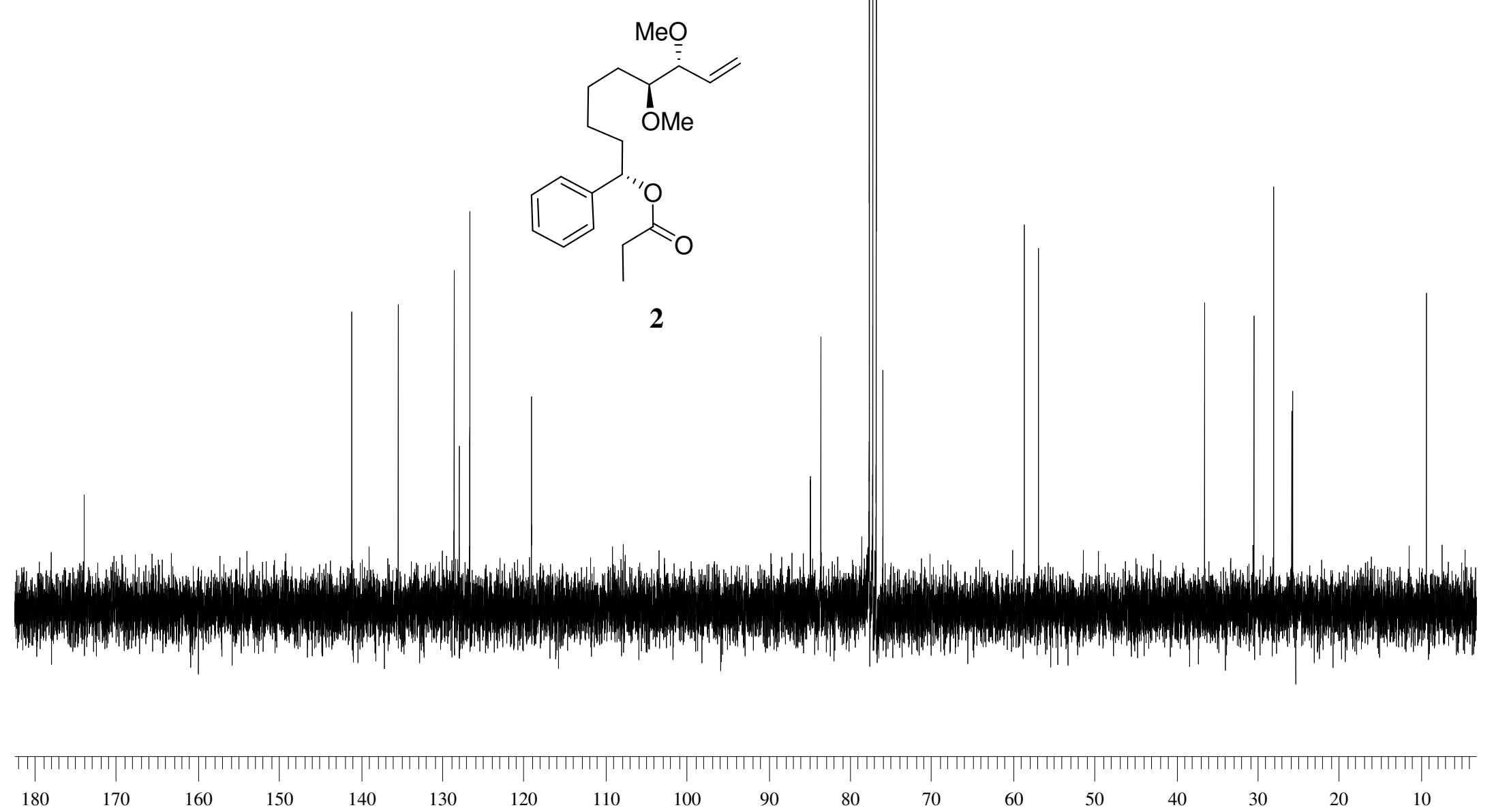

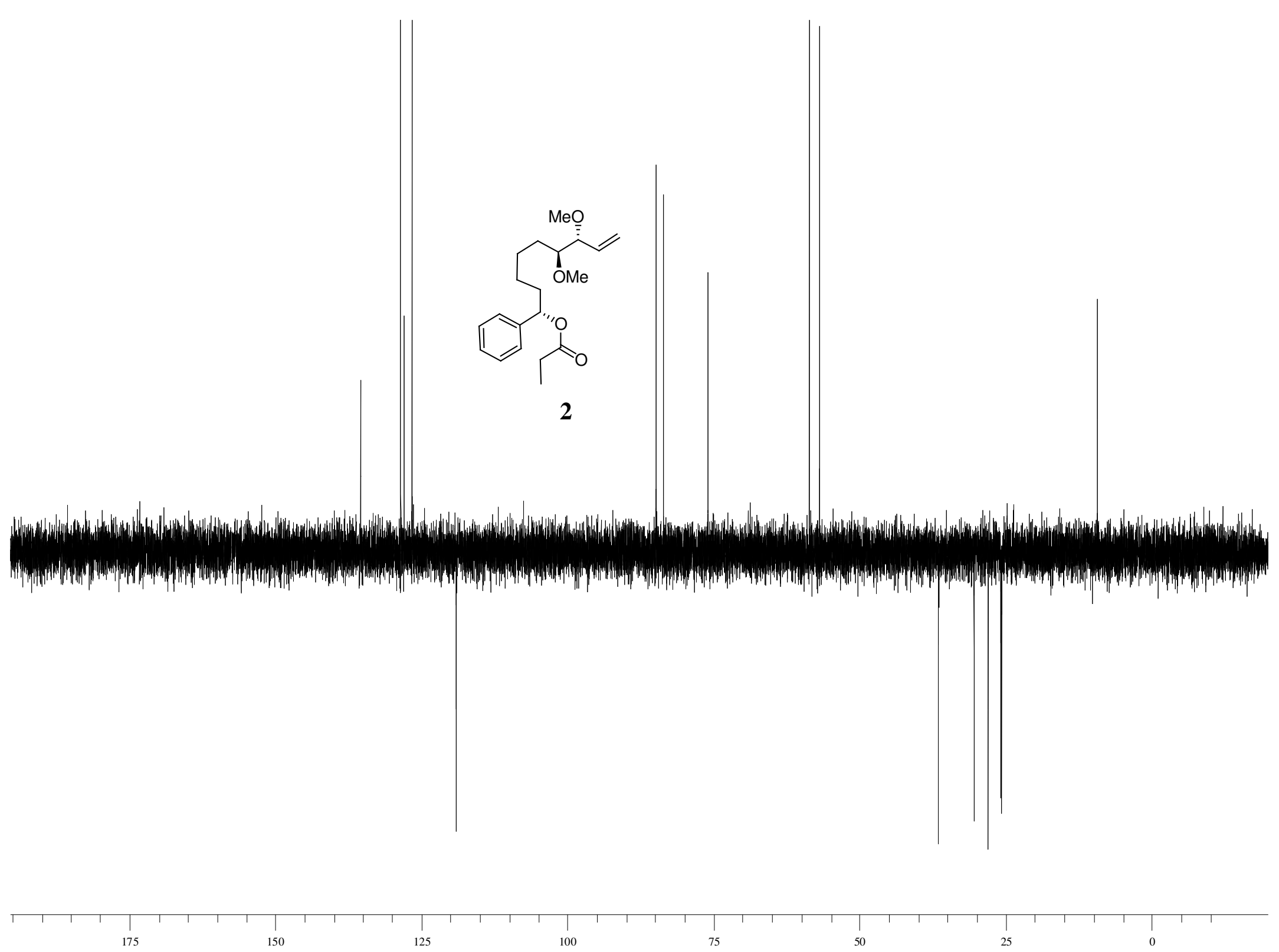


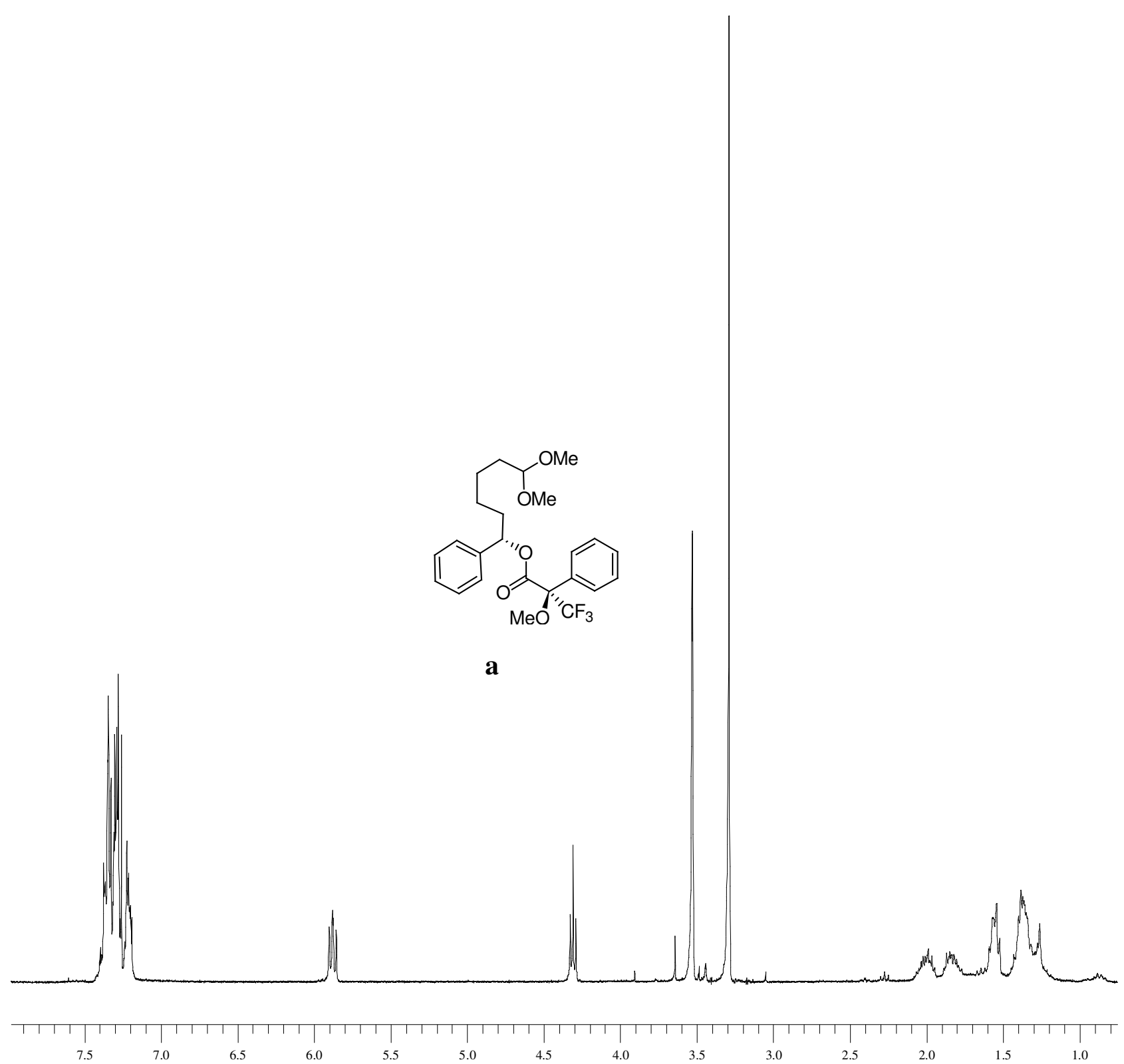



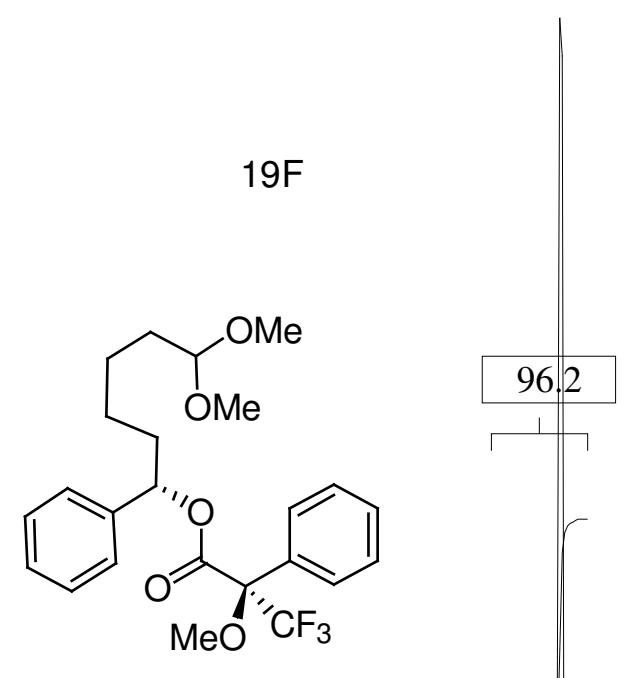

a

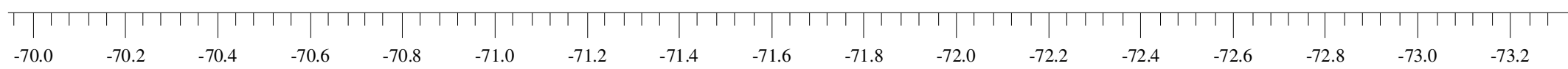




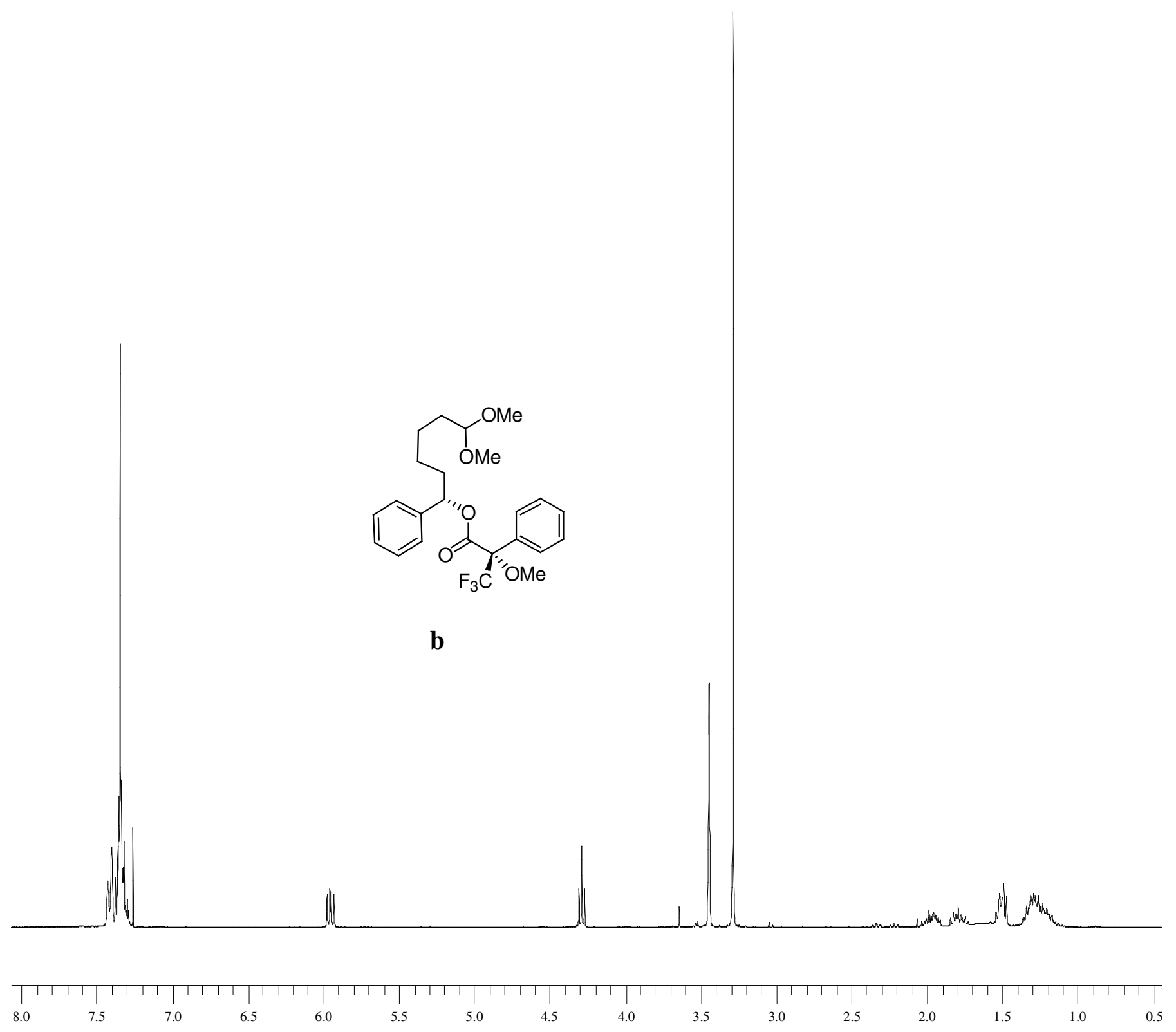




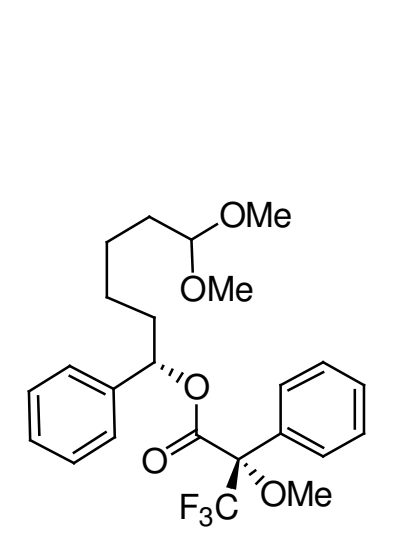

b

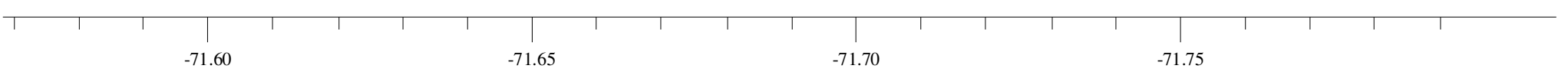


Ciufolini et al.

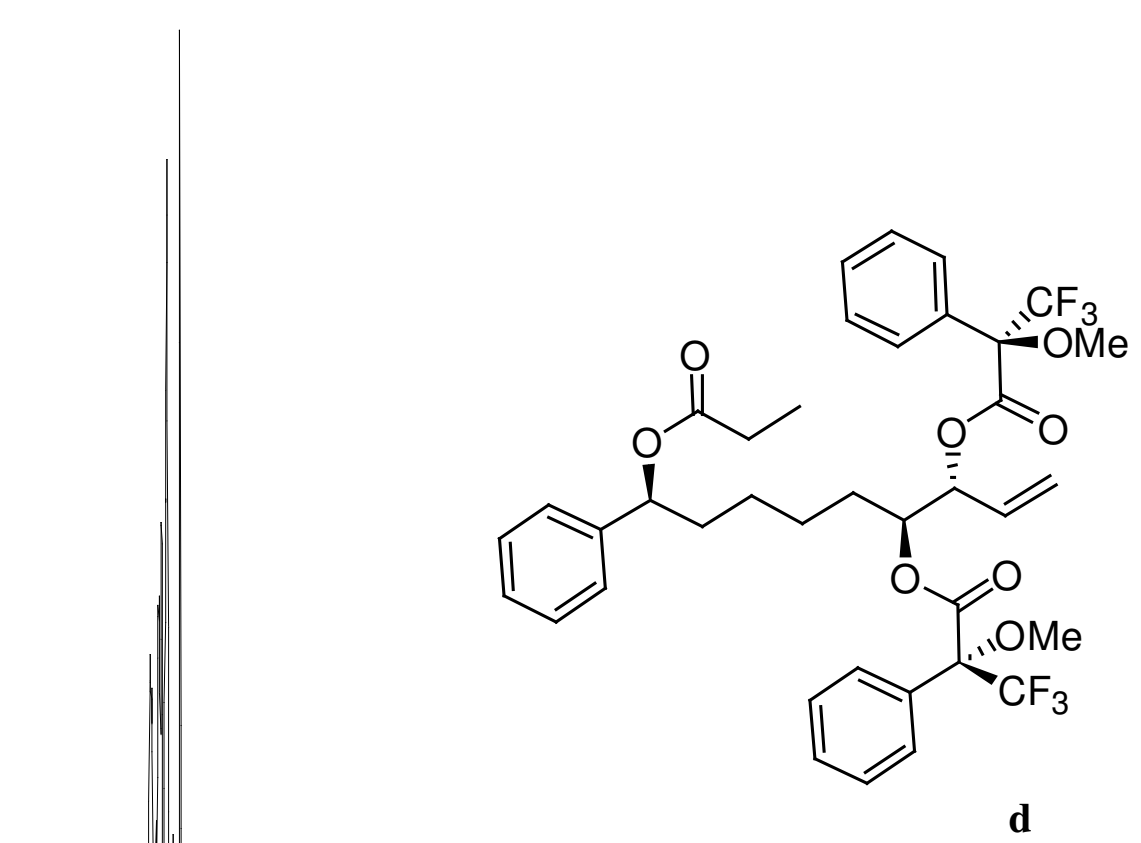

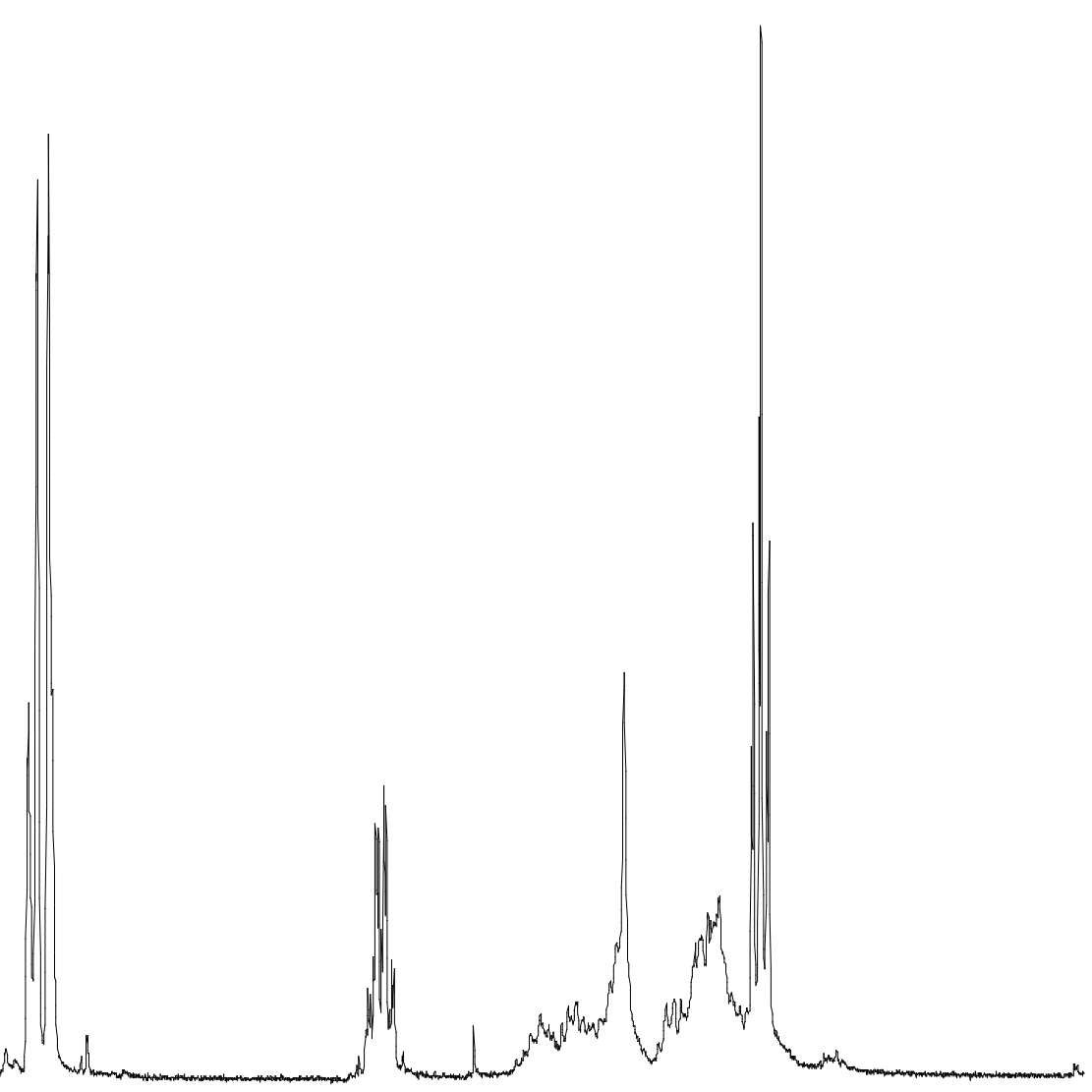

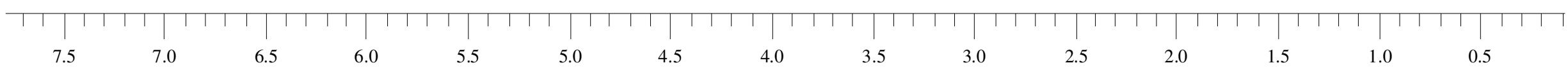


19F<smiles>C=CC[C@H](OC(=O)C(c1ccccc1)(c1ccccc1)C(C)(F)F)C(CCCCC(OC(=O)CC)c1ccccc1)OC(=O)C(c1ccccc1)(c1ccccc1)C(F)(F)F</smiles>

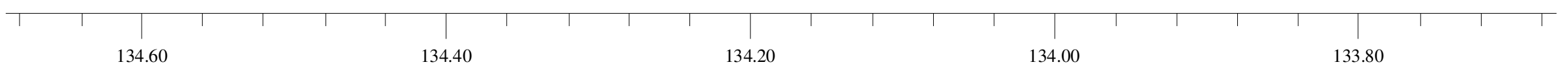



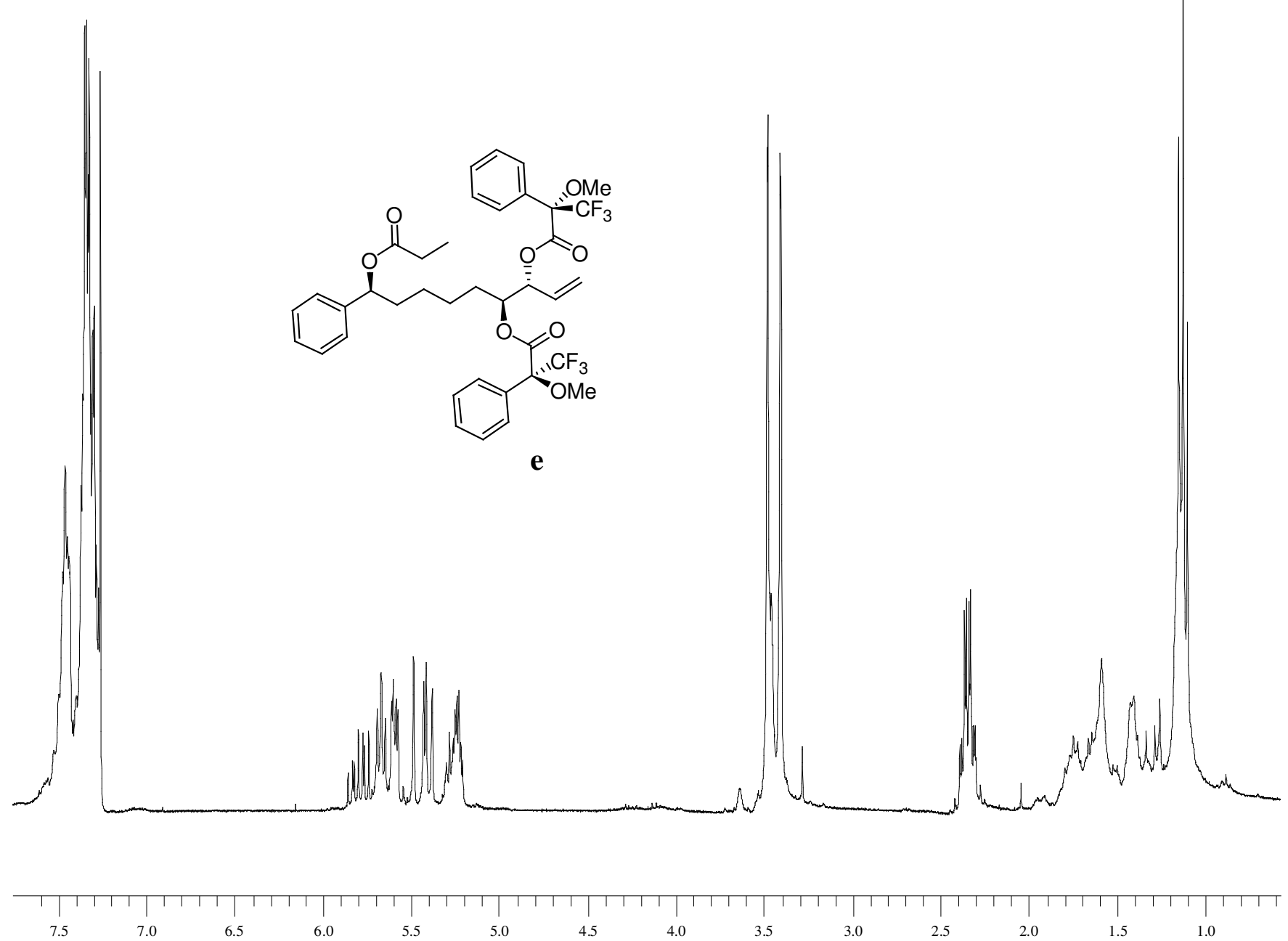
Ciufolini et al.

Studies toward Soraphen A

S 39

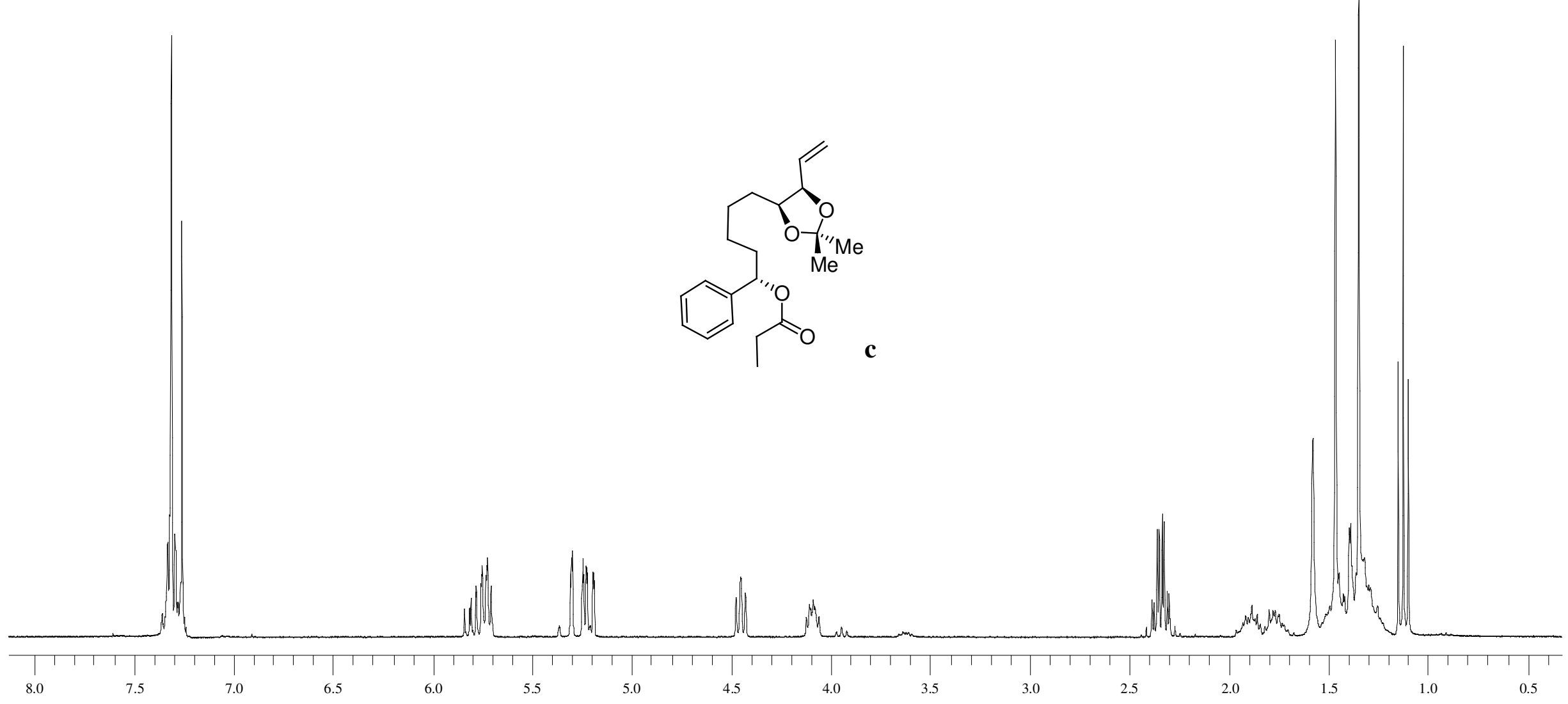




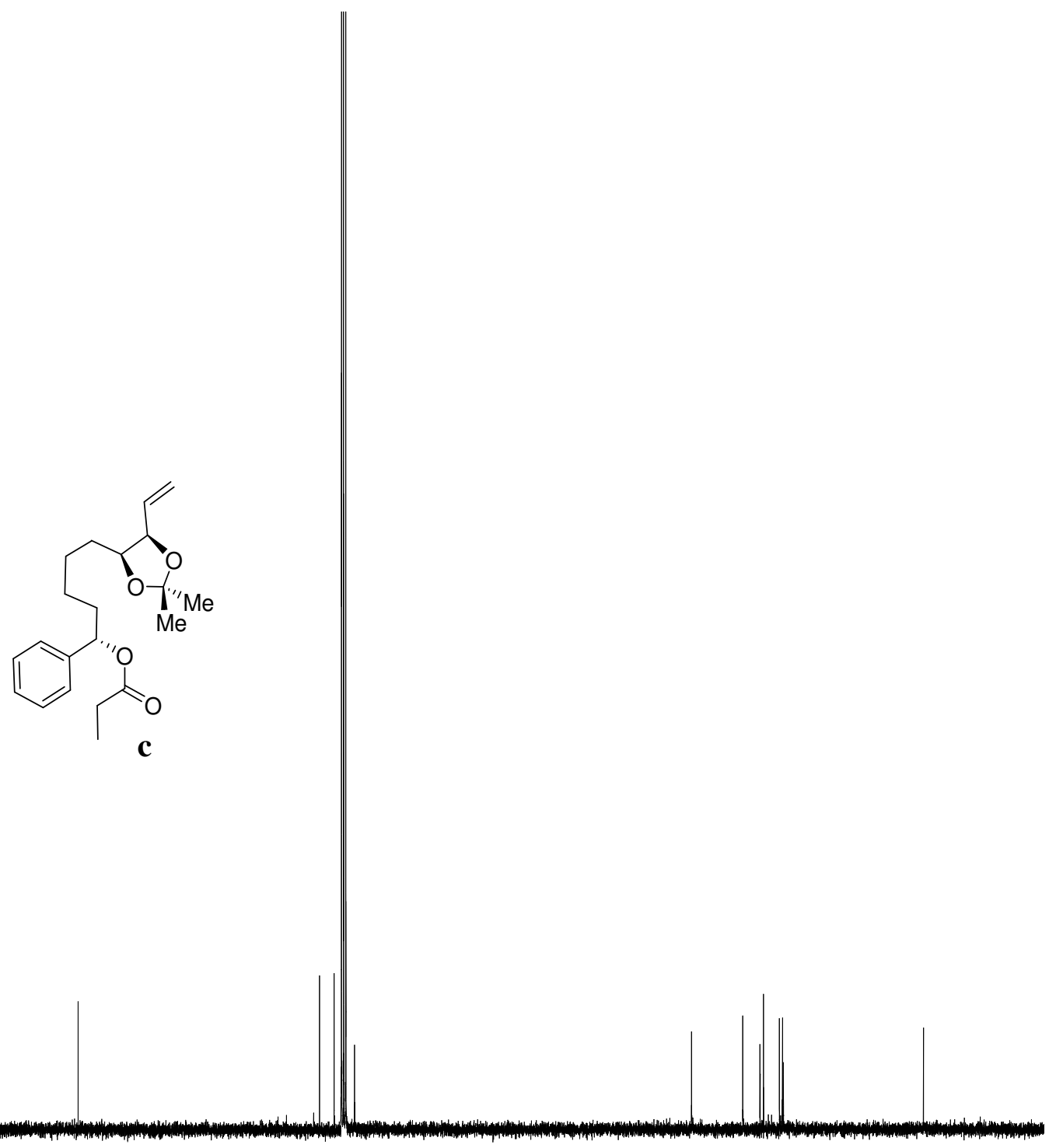

(1) (190 170 (1)

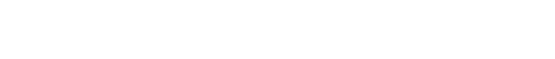




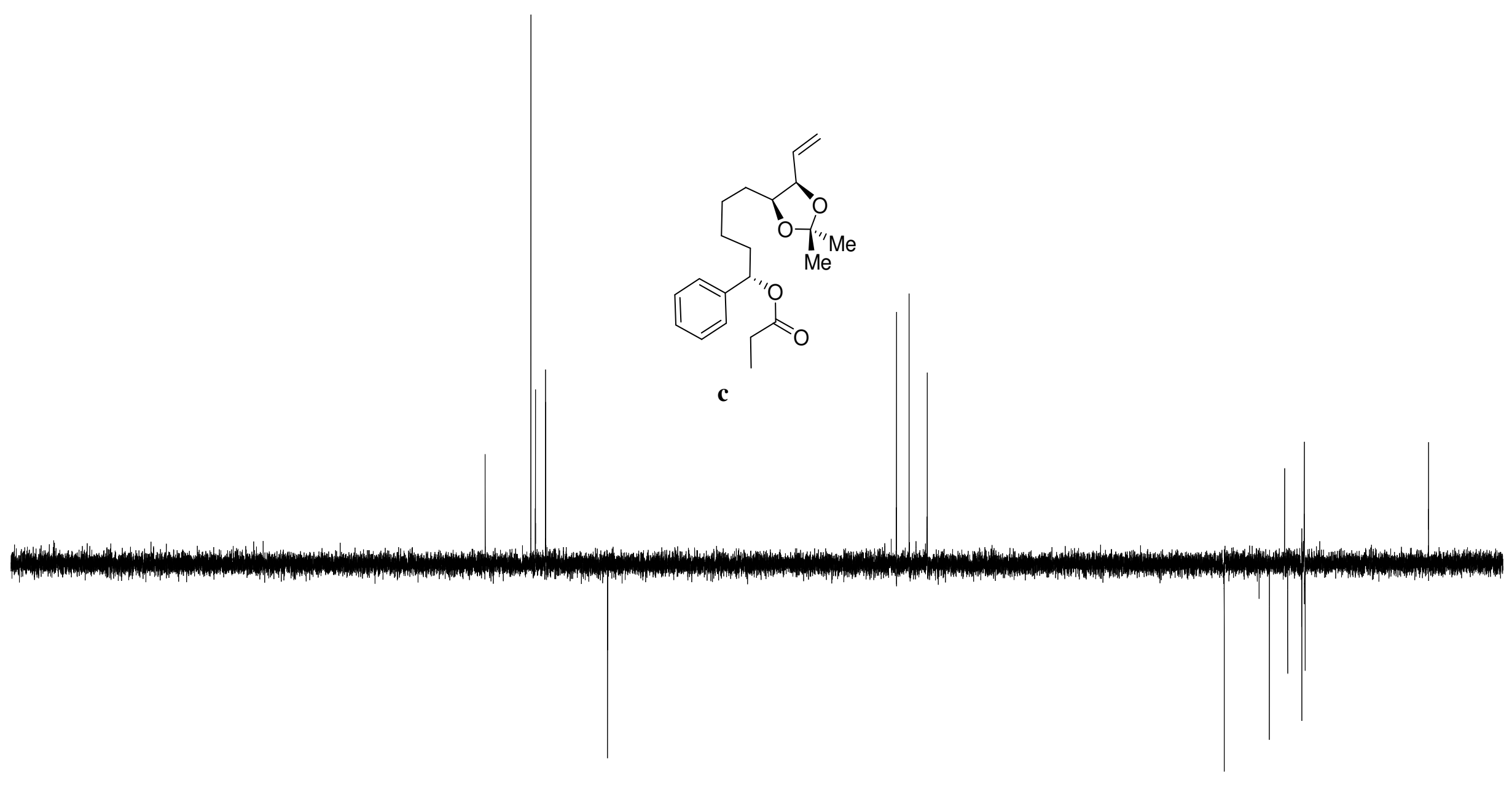




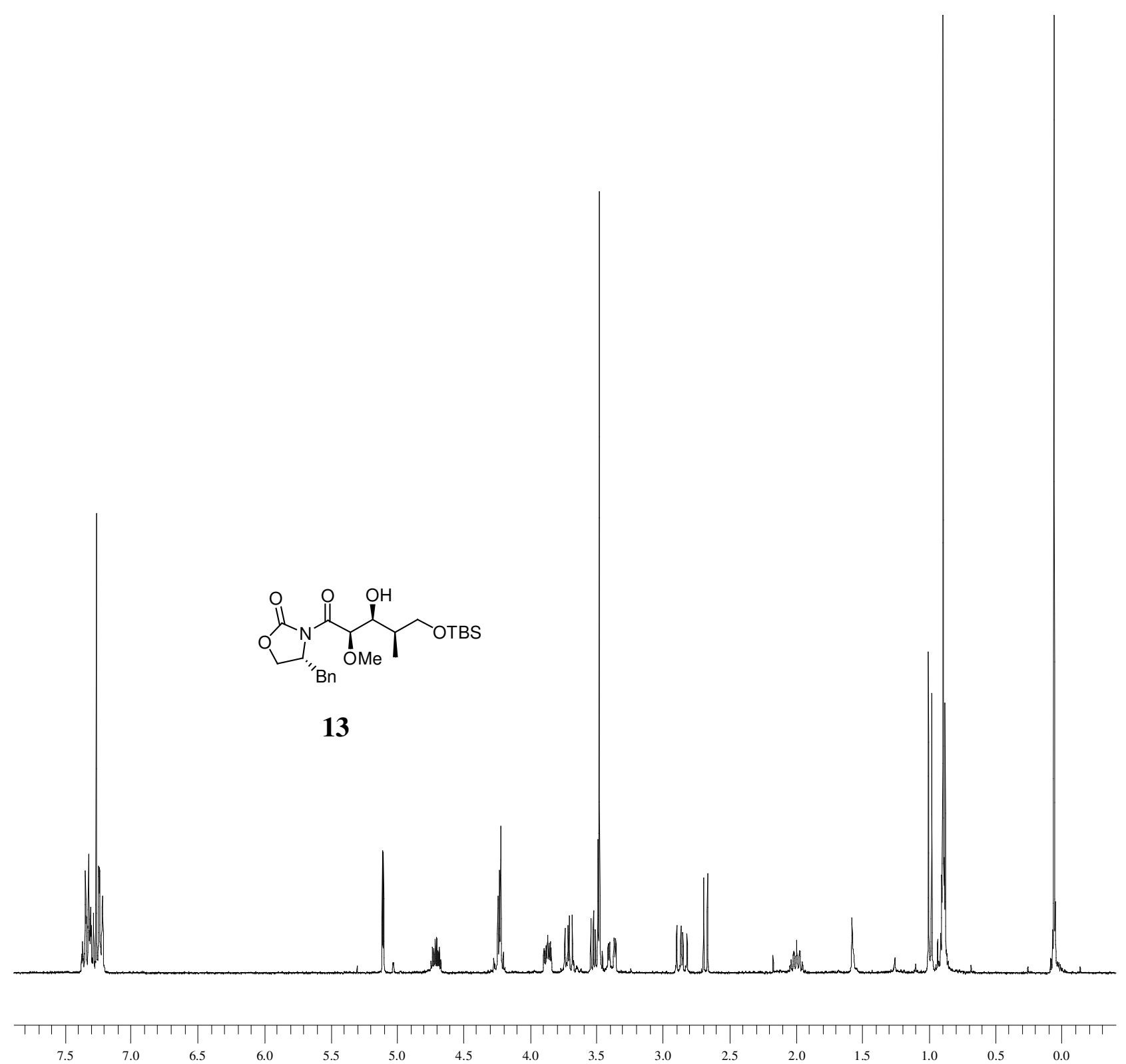




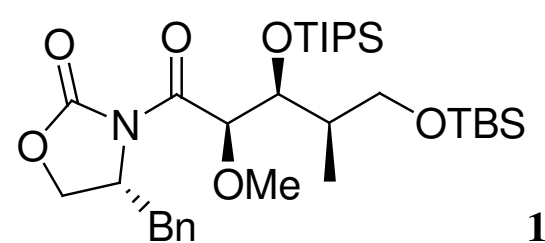

14

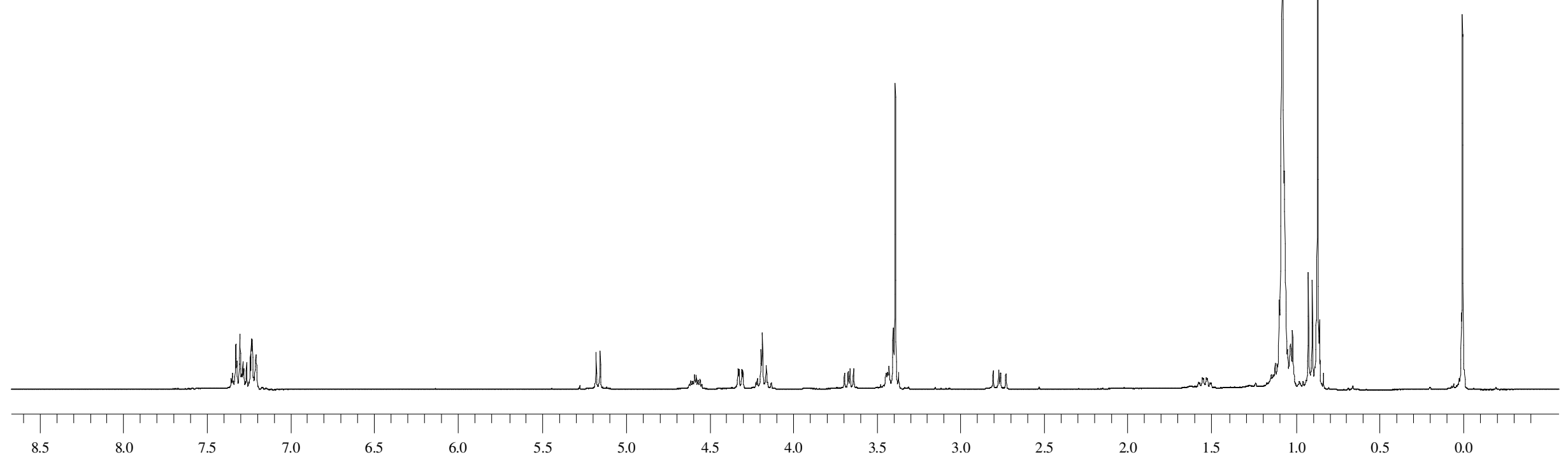




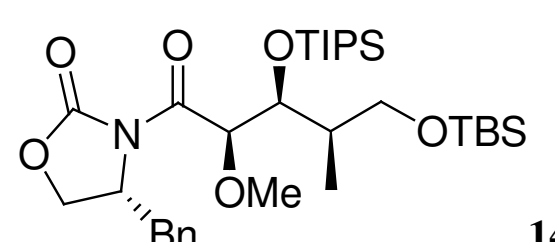

14
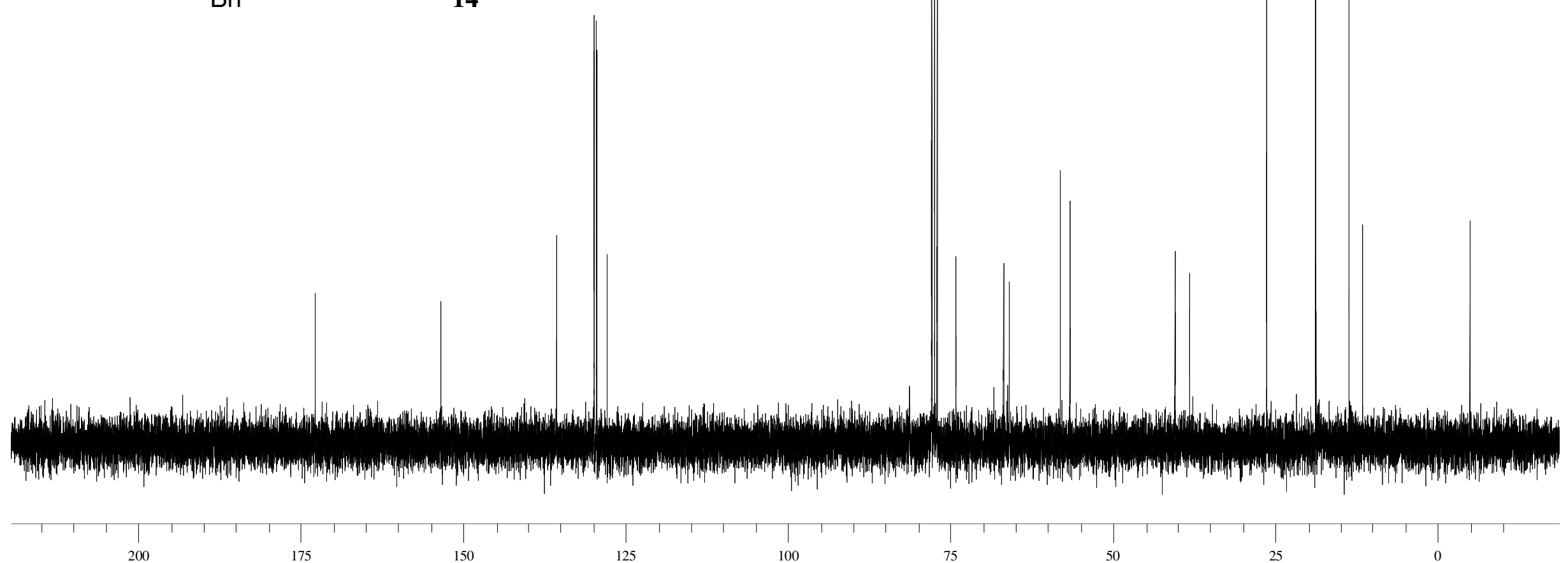

200

175

150

125

100

75

50

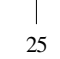



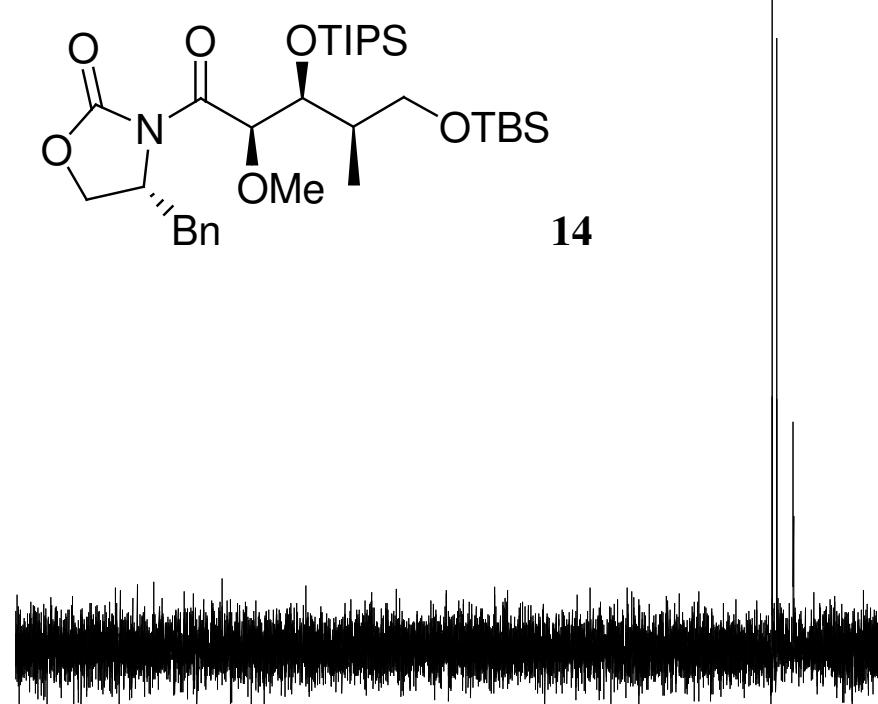

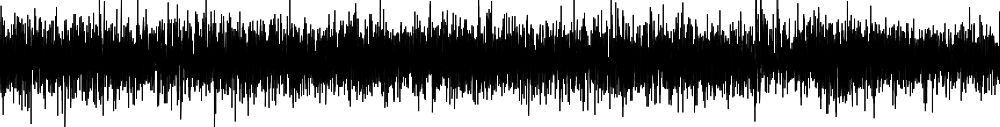

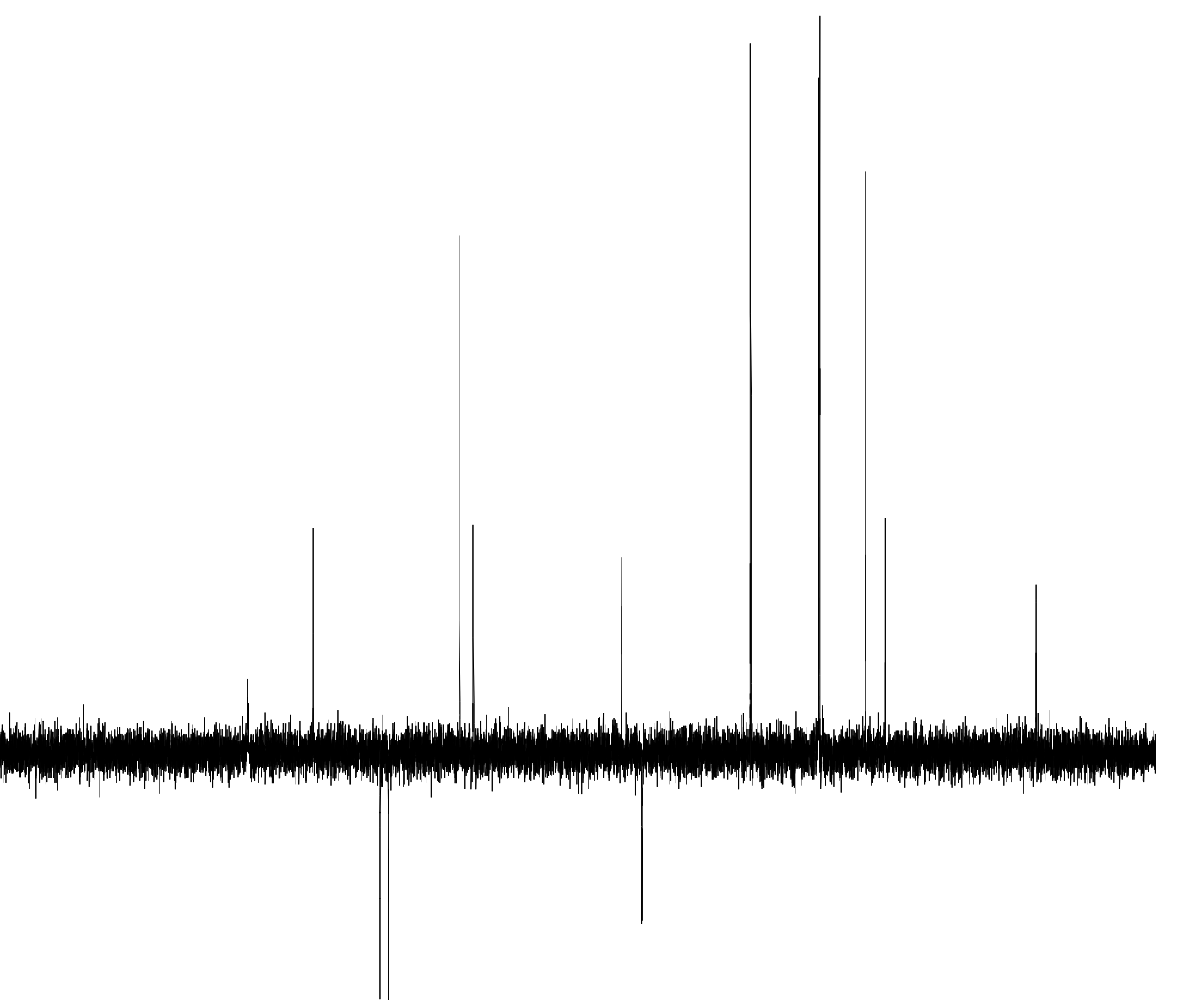




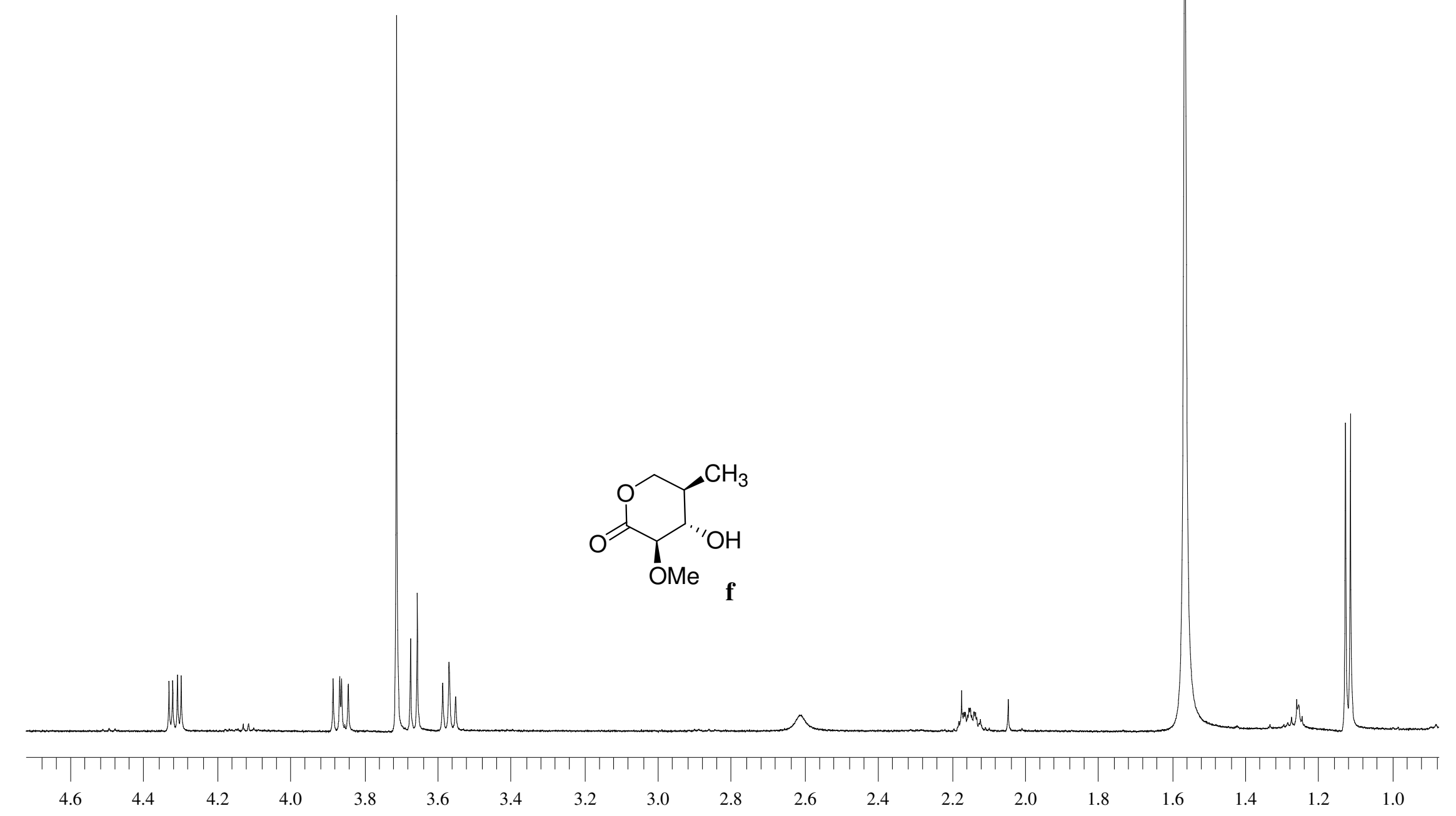




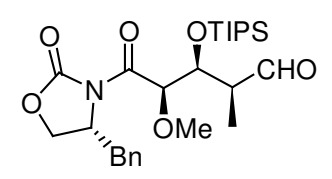

15
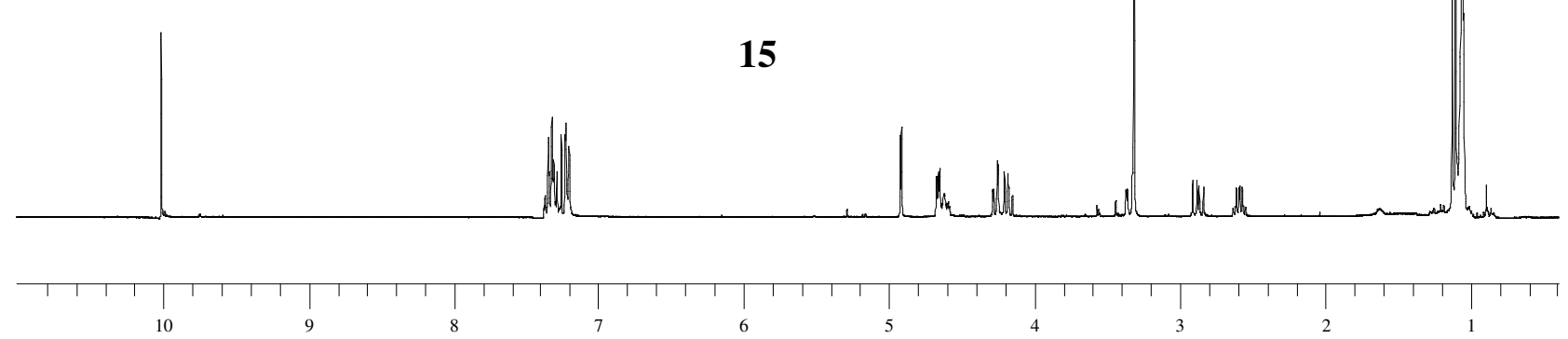


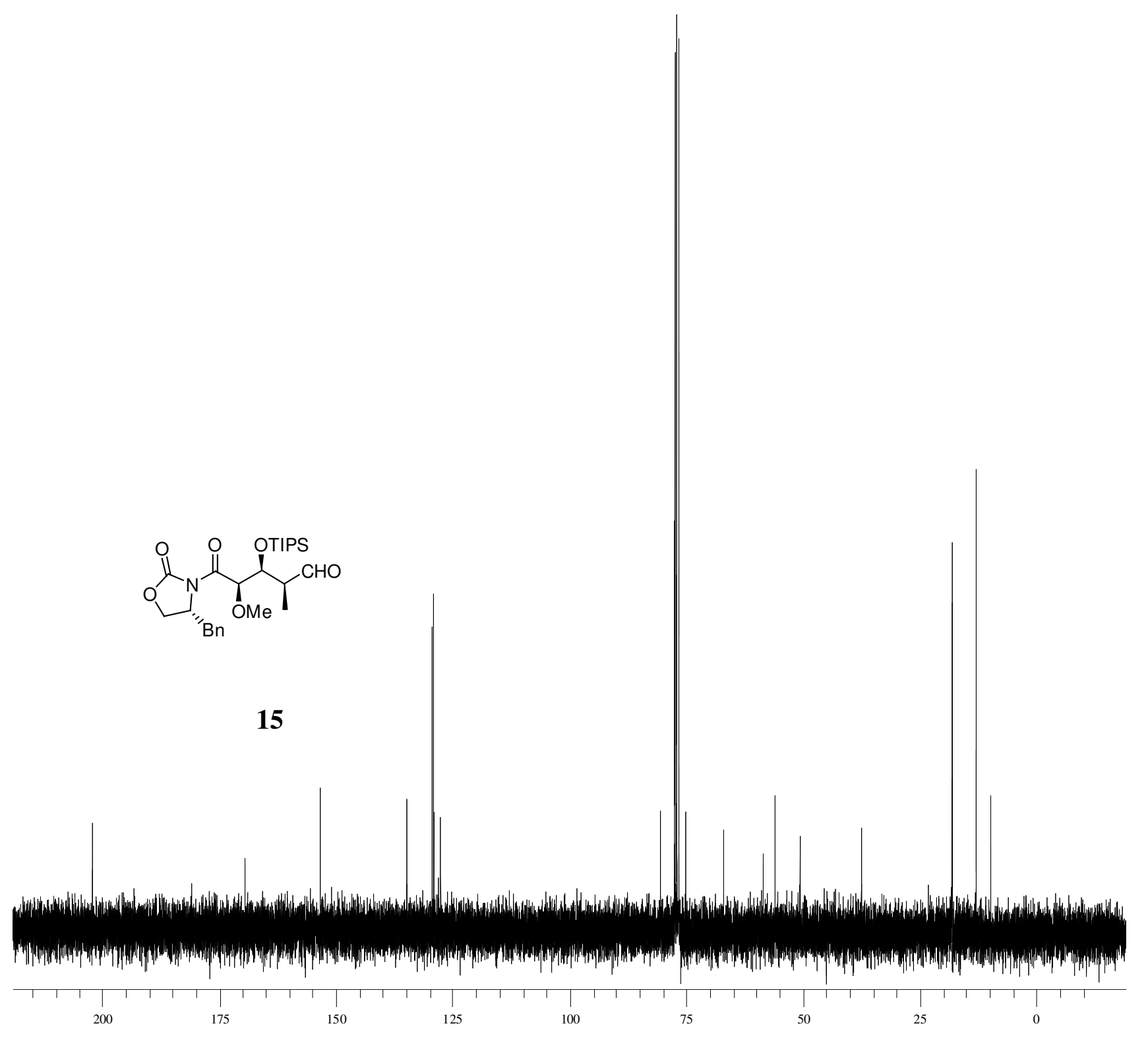




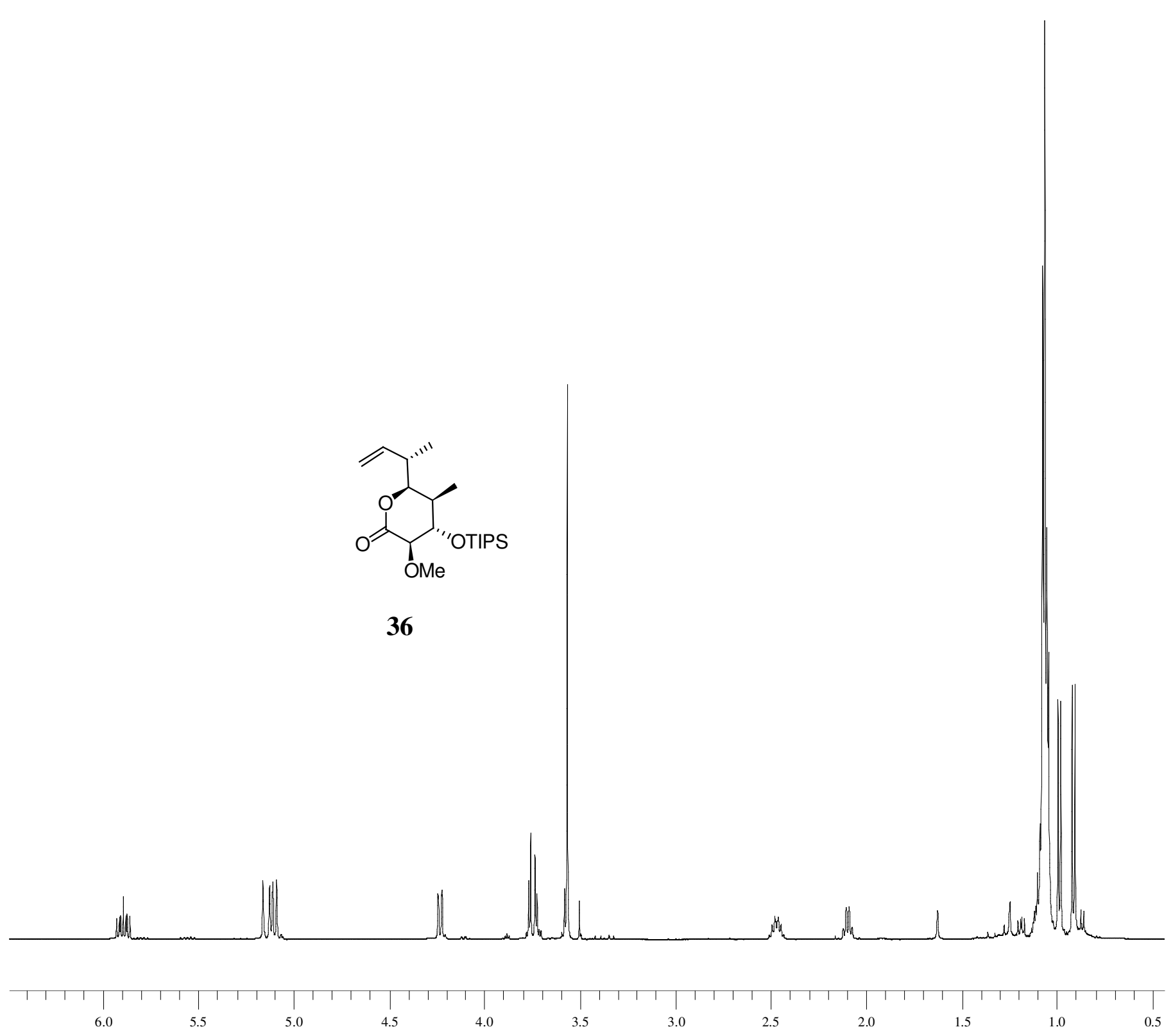




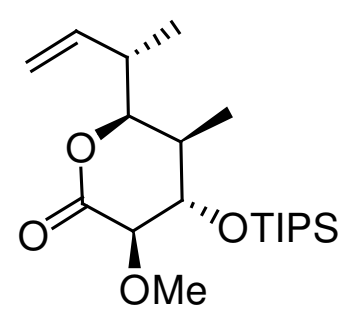

36

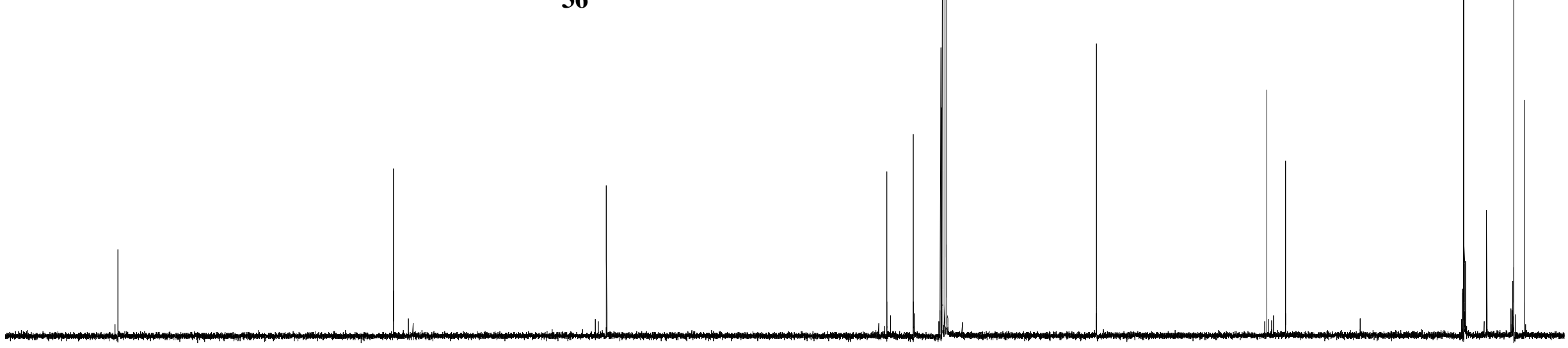

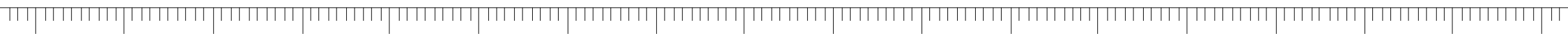




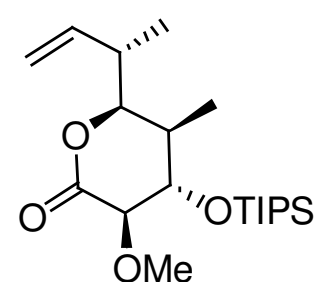

36 


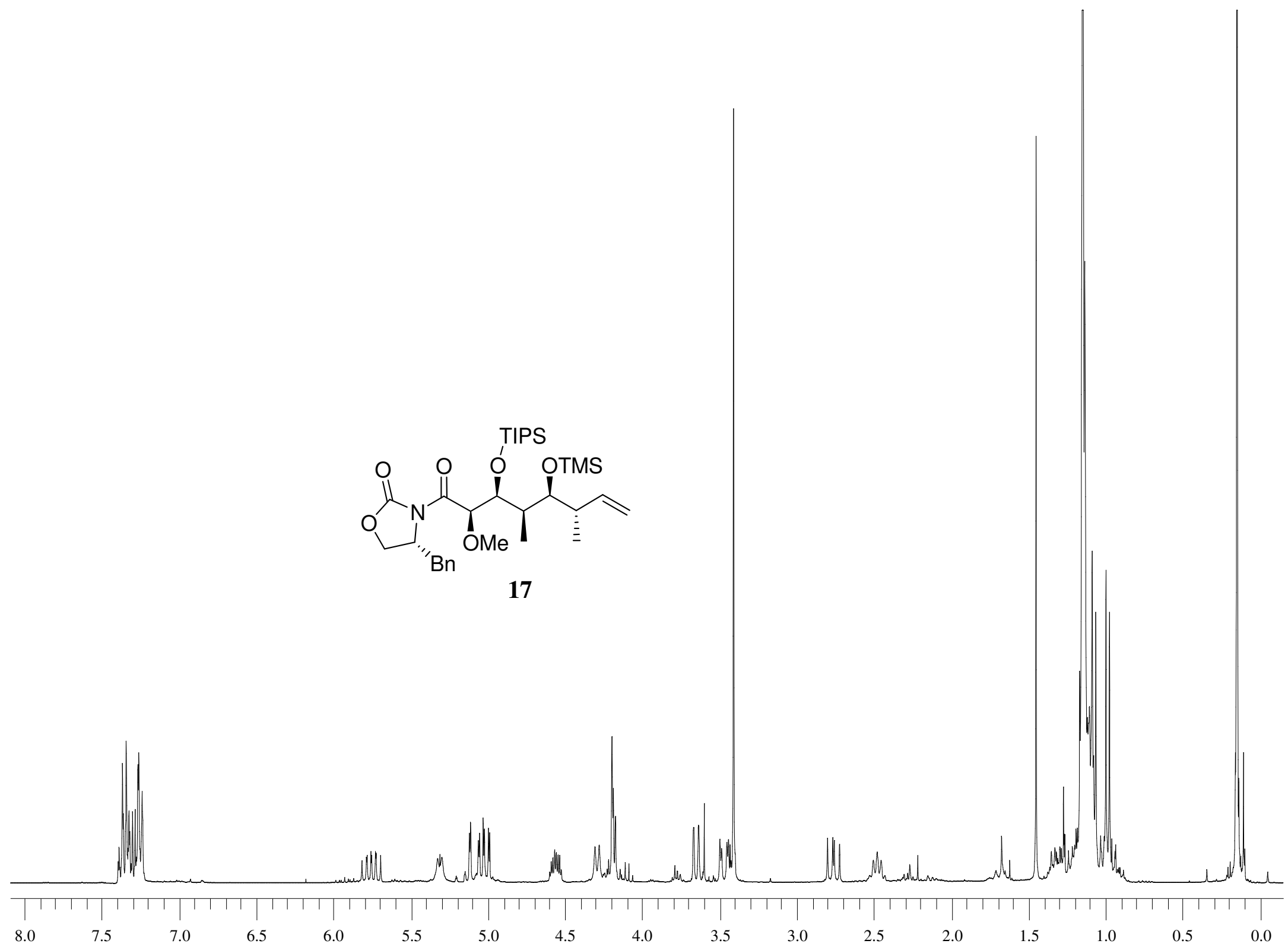




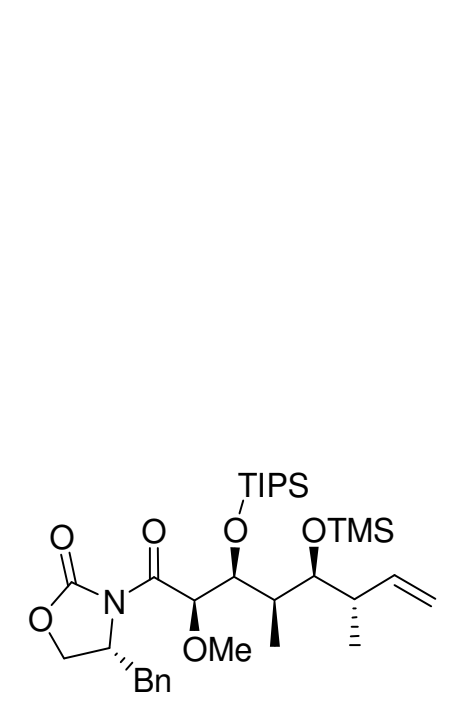

17

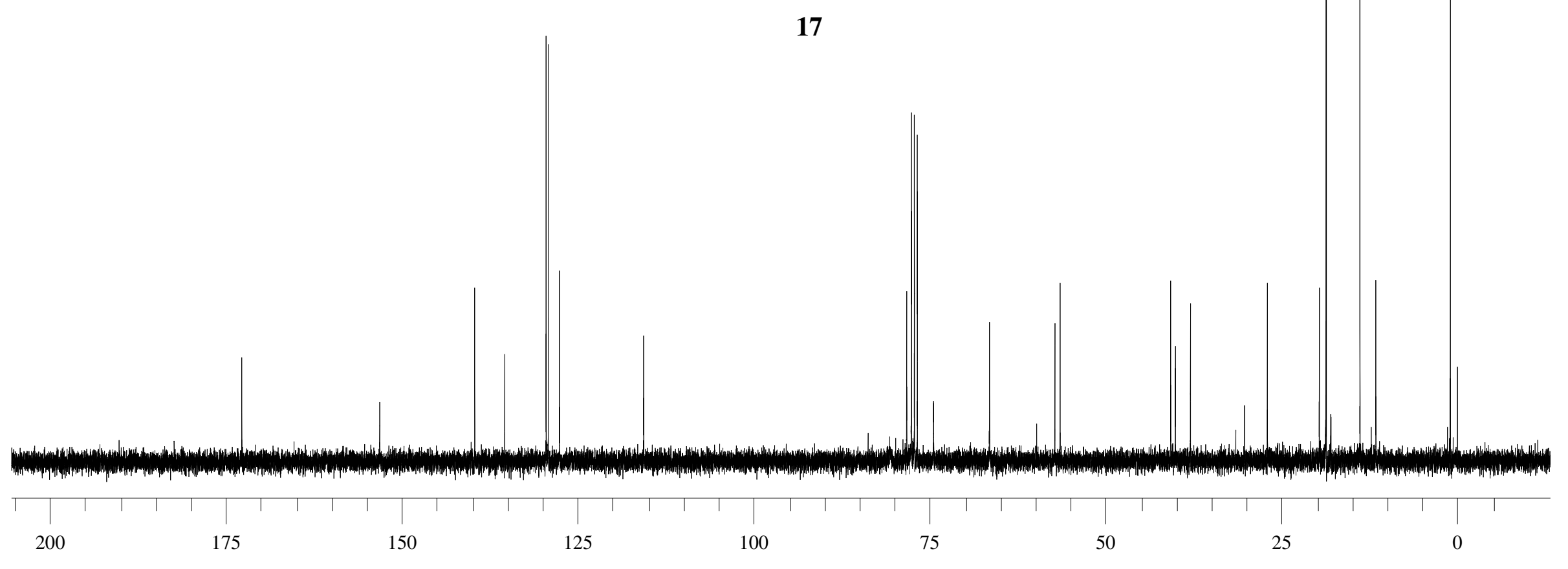




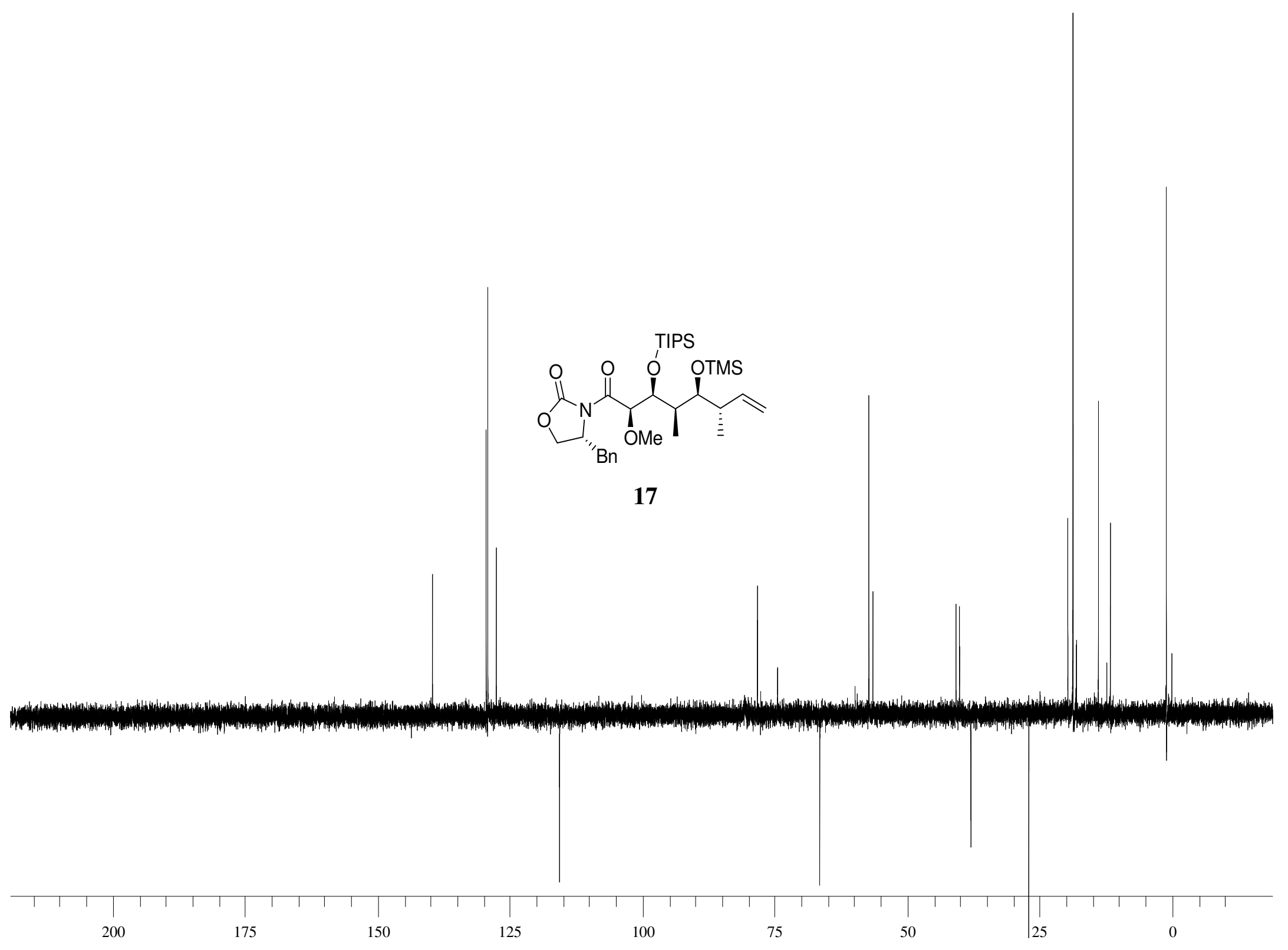




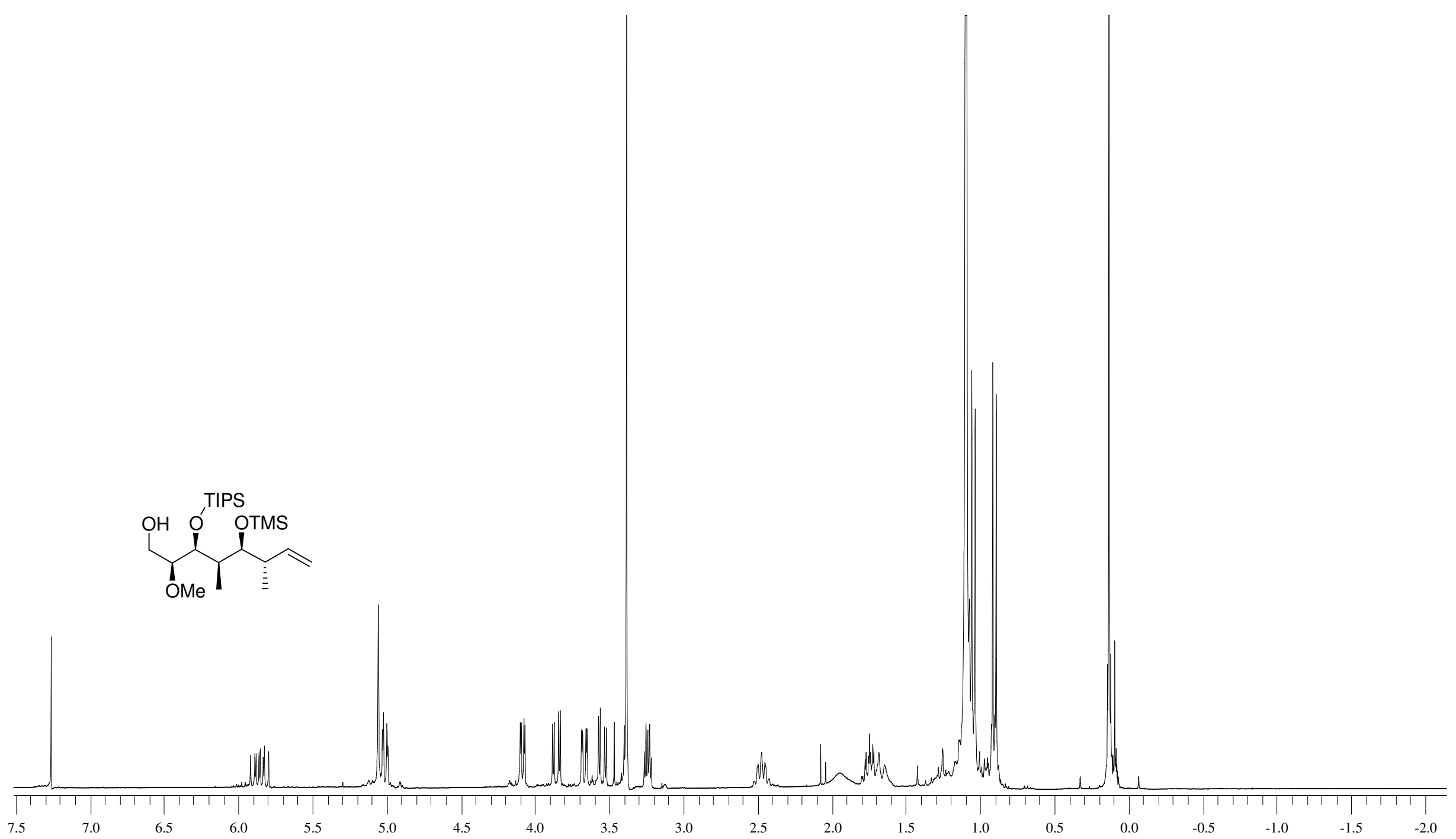


TIPS

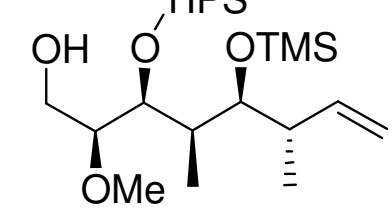

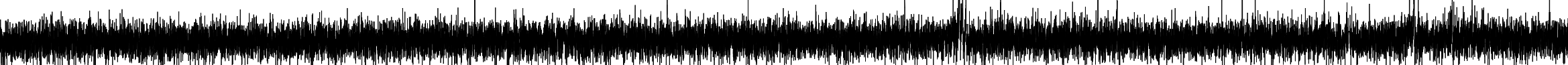

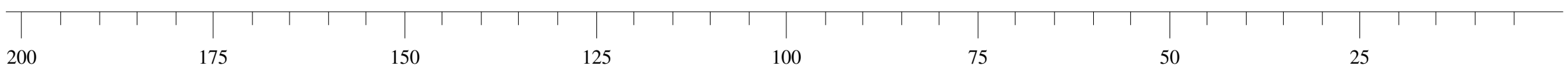



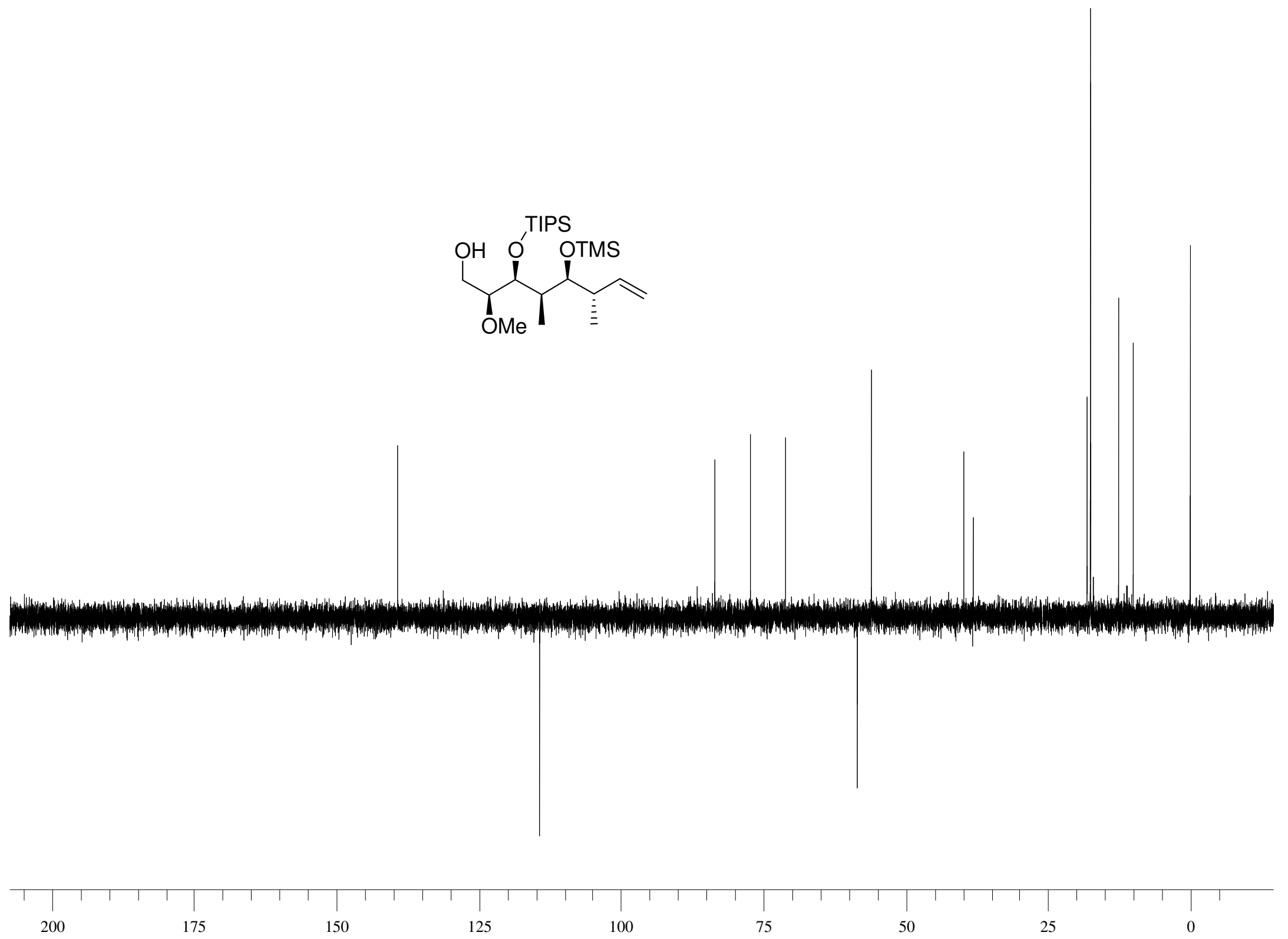


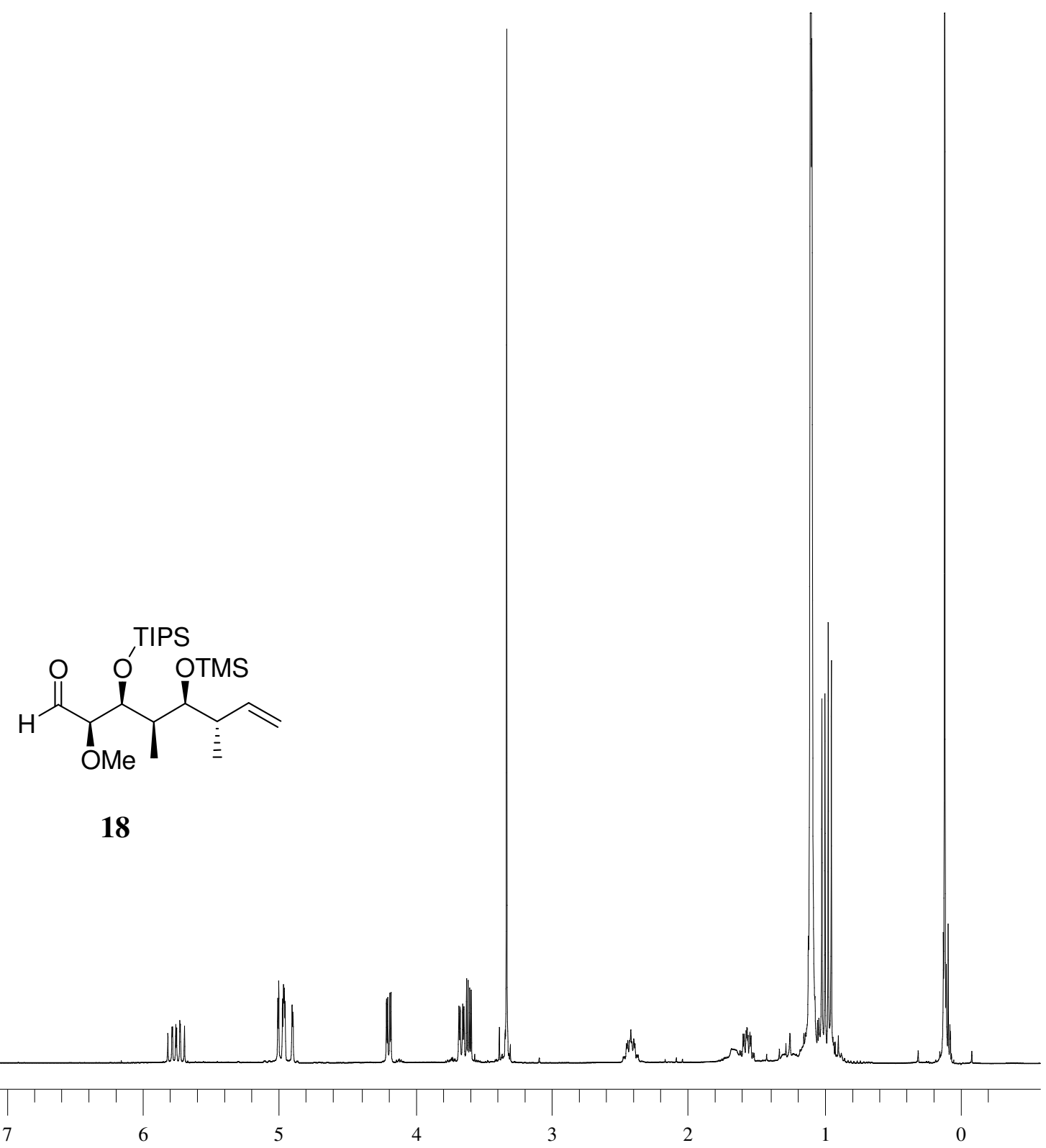




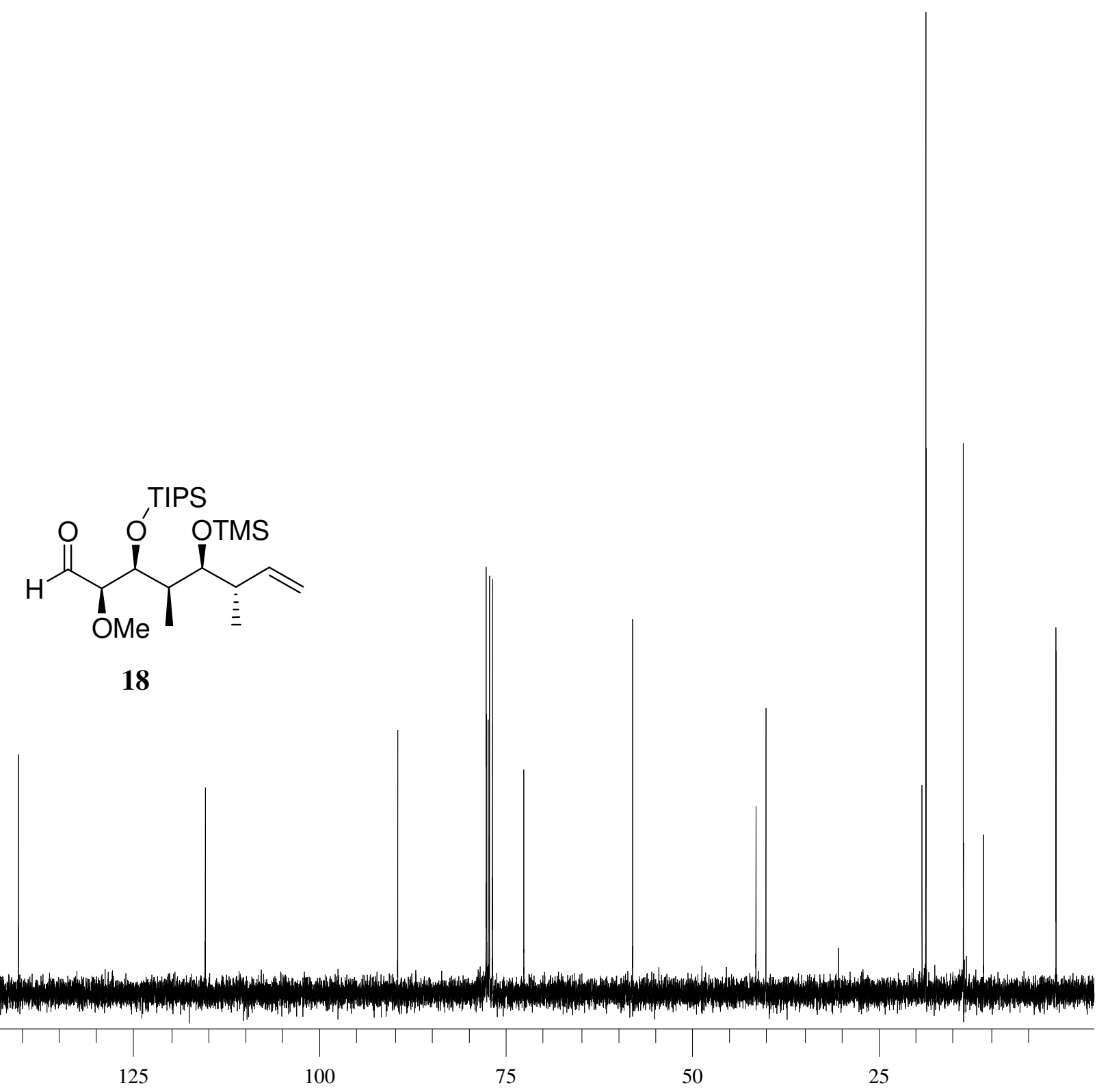




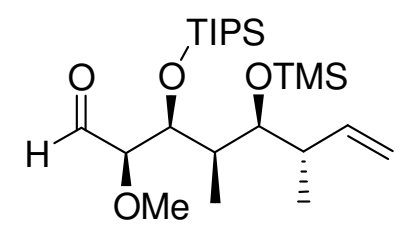

18

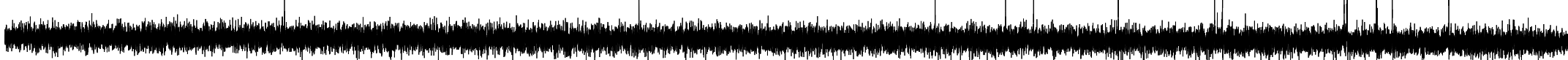

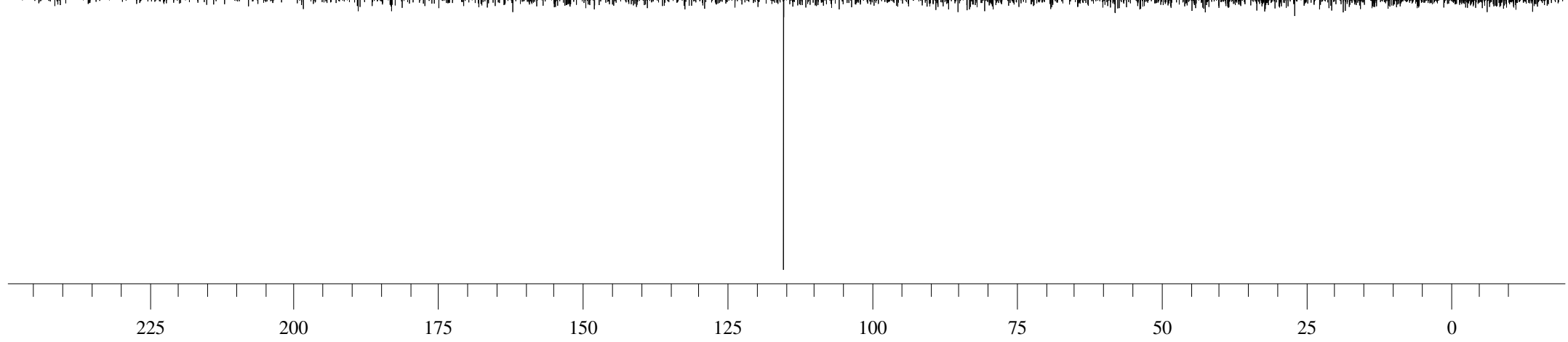


Ciufolini et al.

Studies toward Soraphen A

S 61

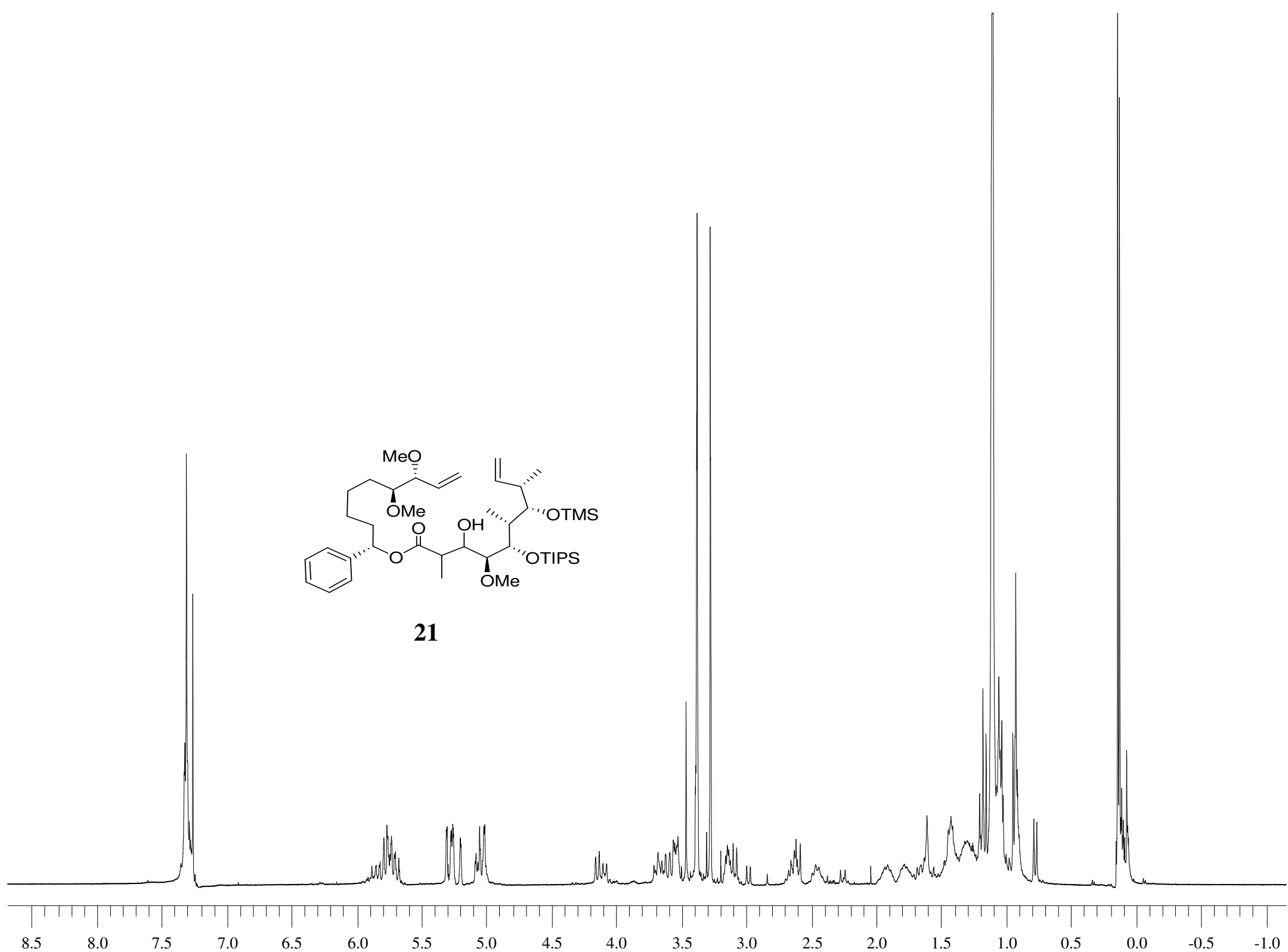




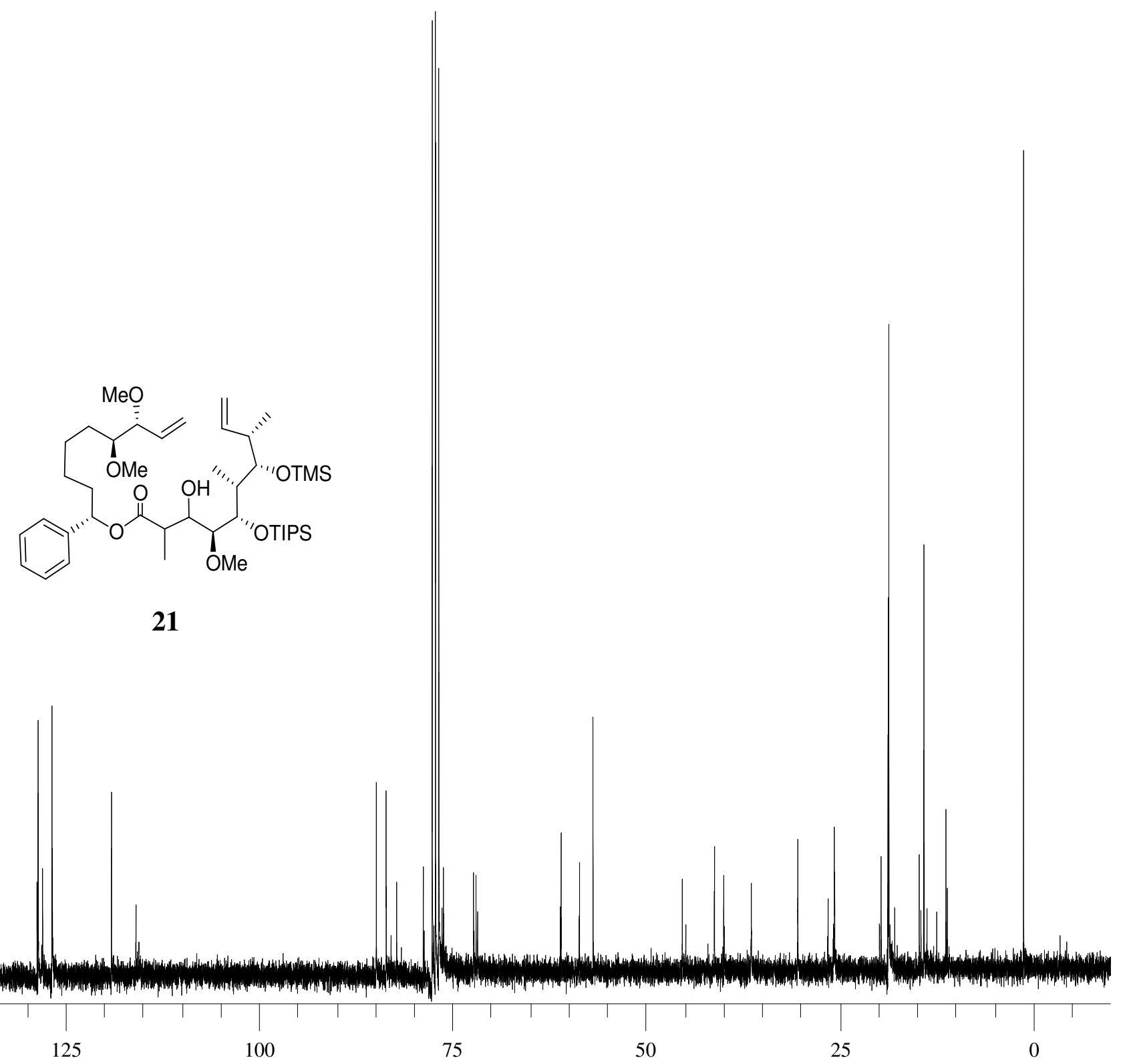




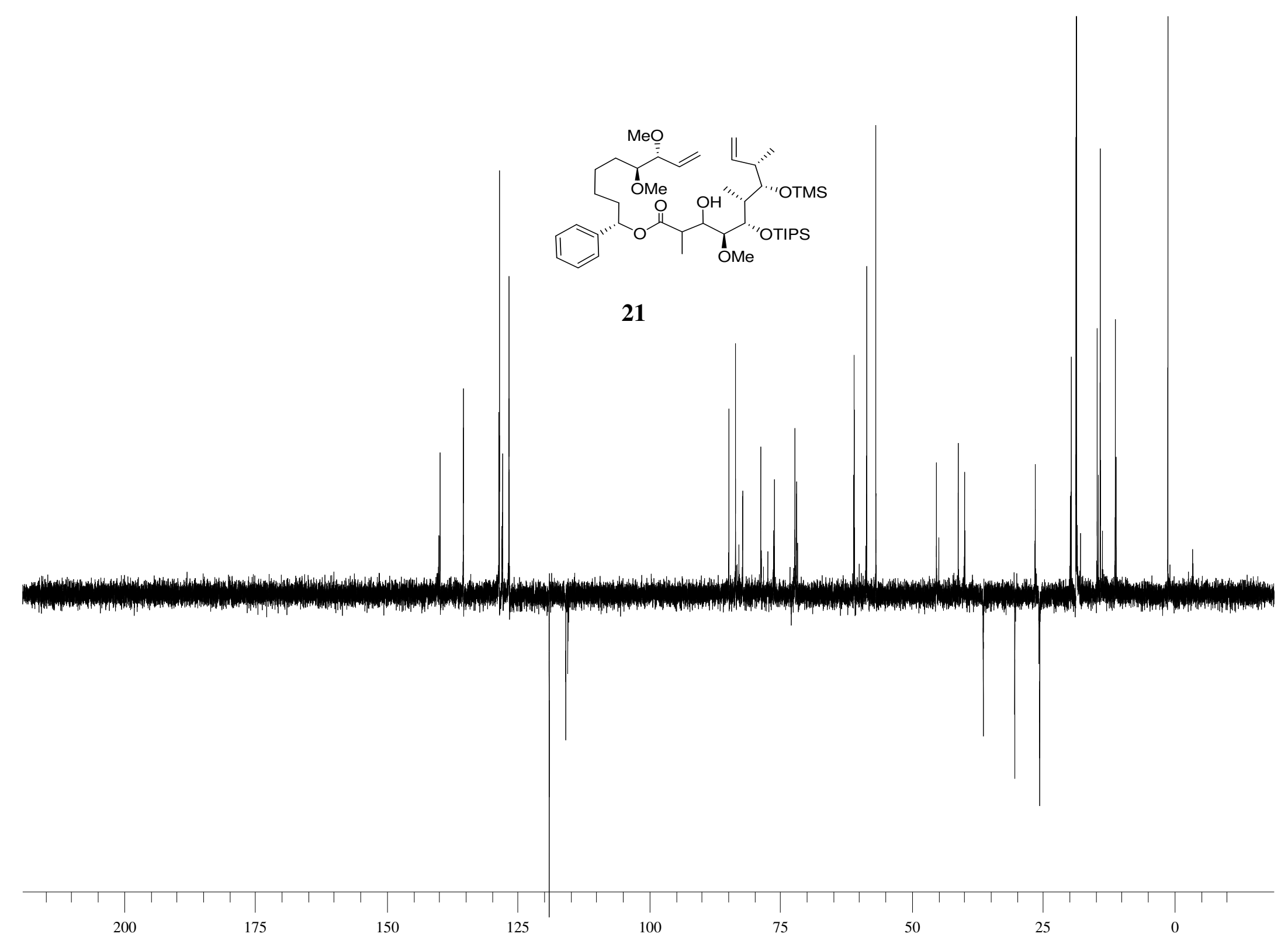


Ciufolini et al.

Studies toward Soraphen A

S 64

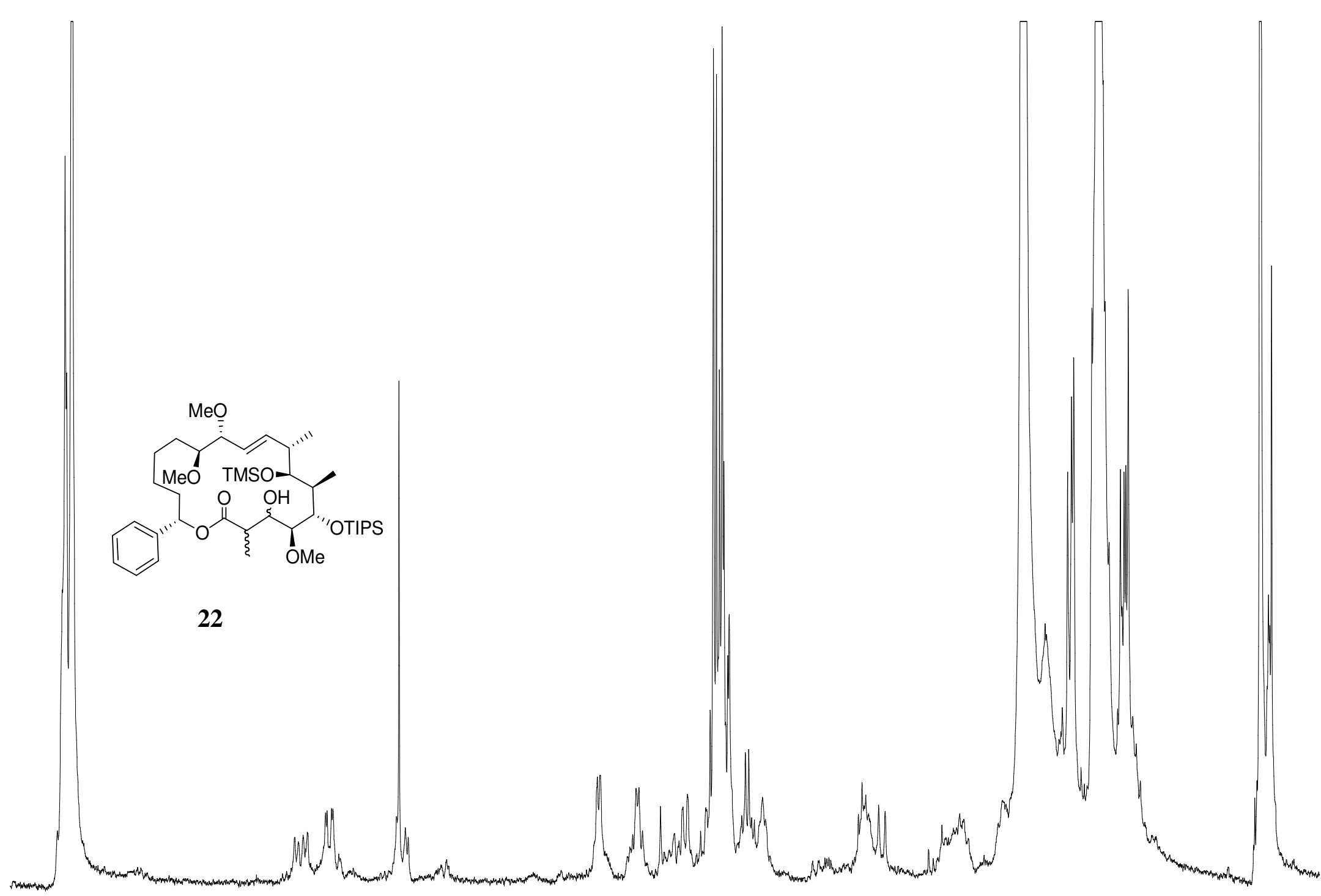

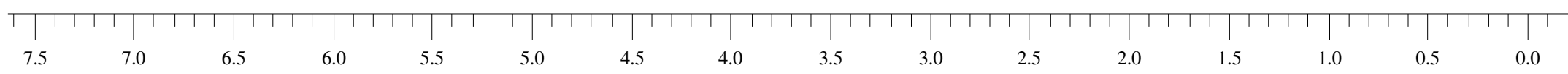


Ciufolini et al.

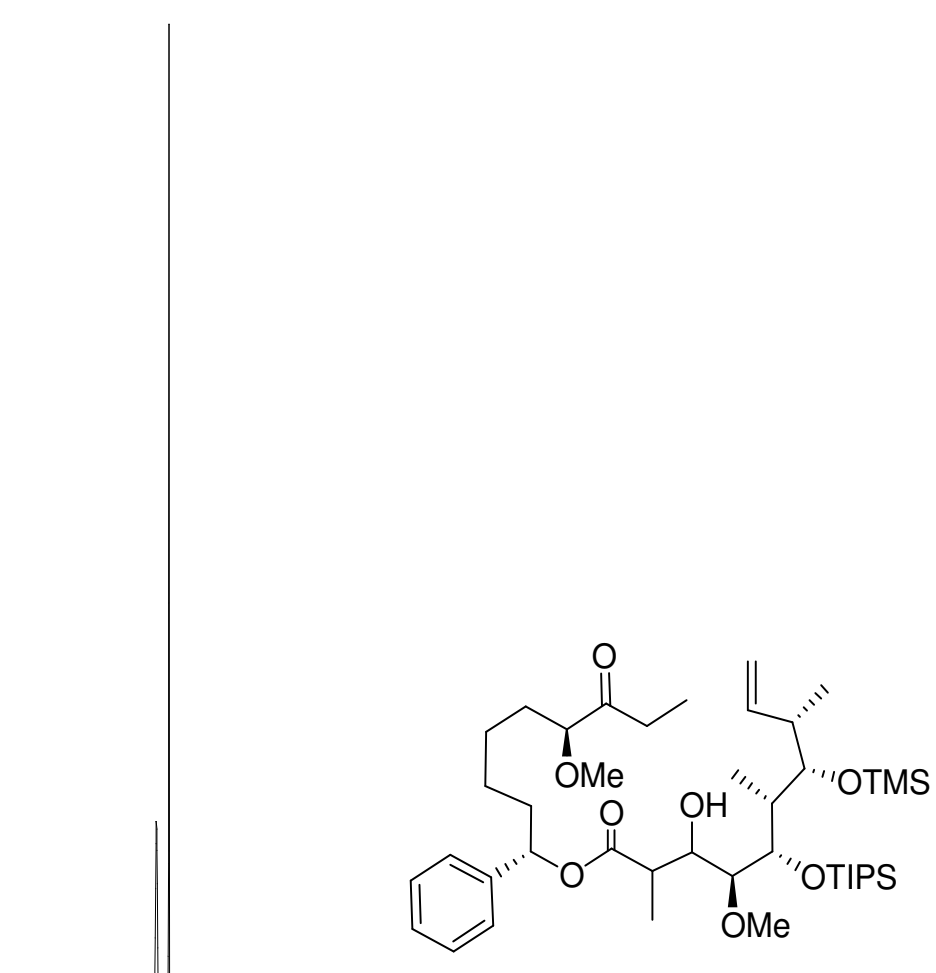

23

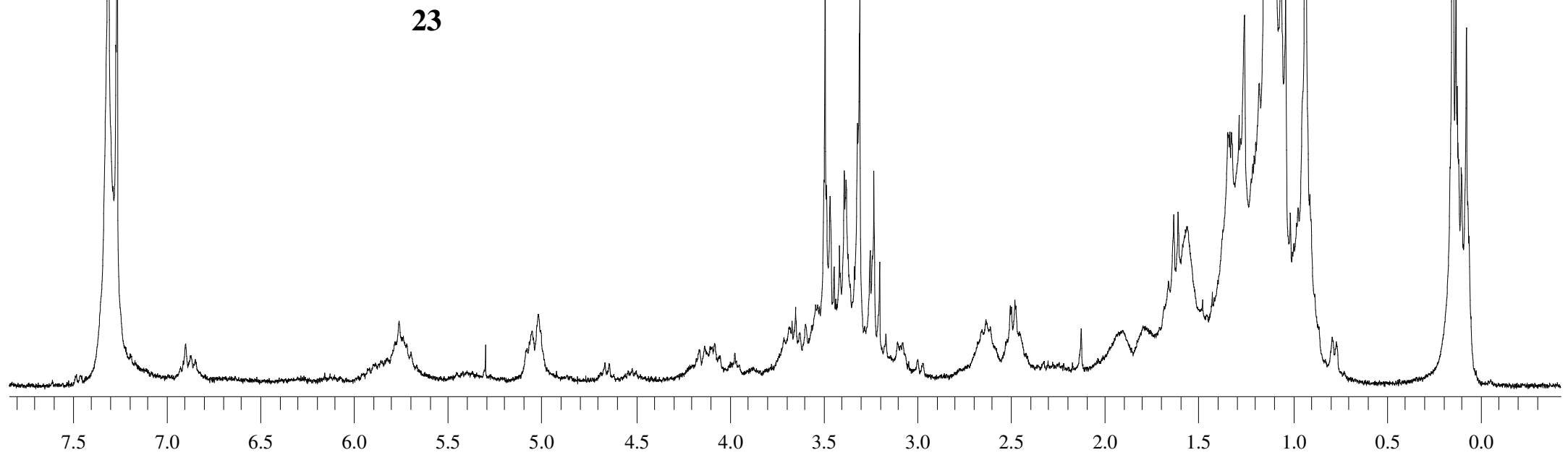



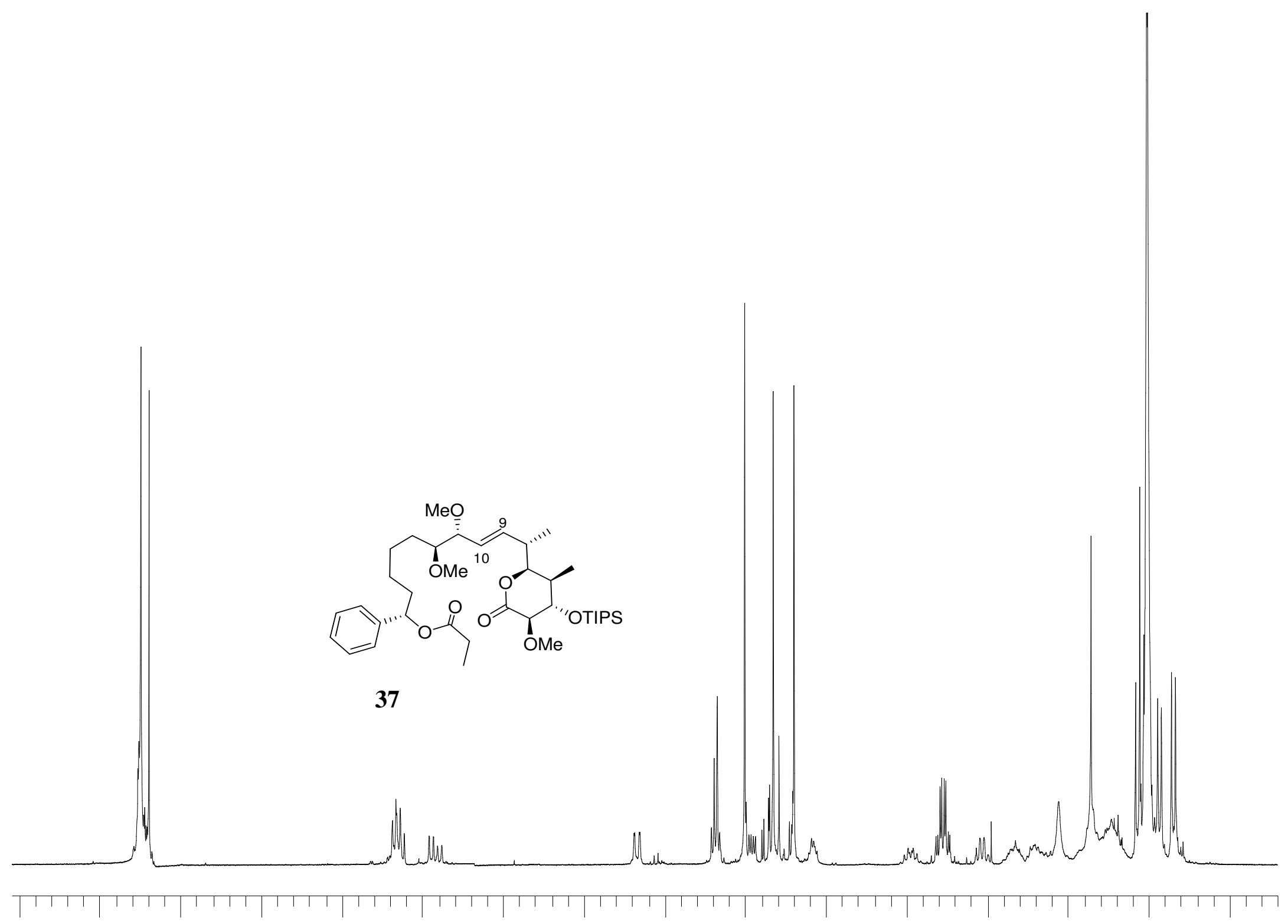


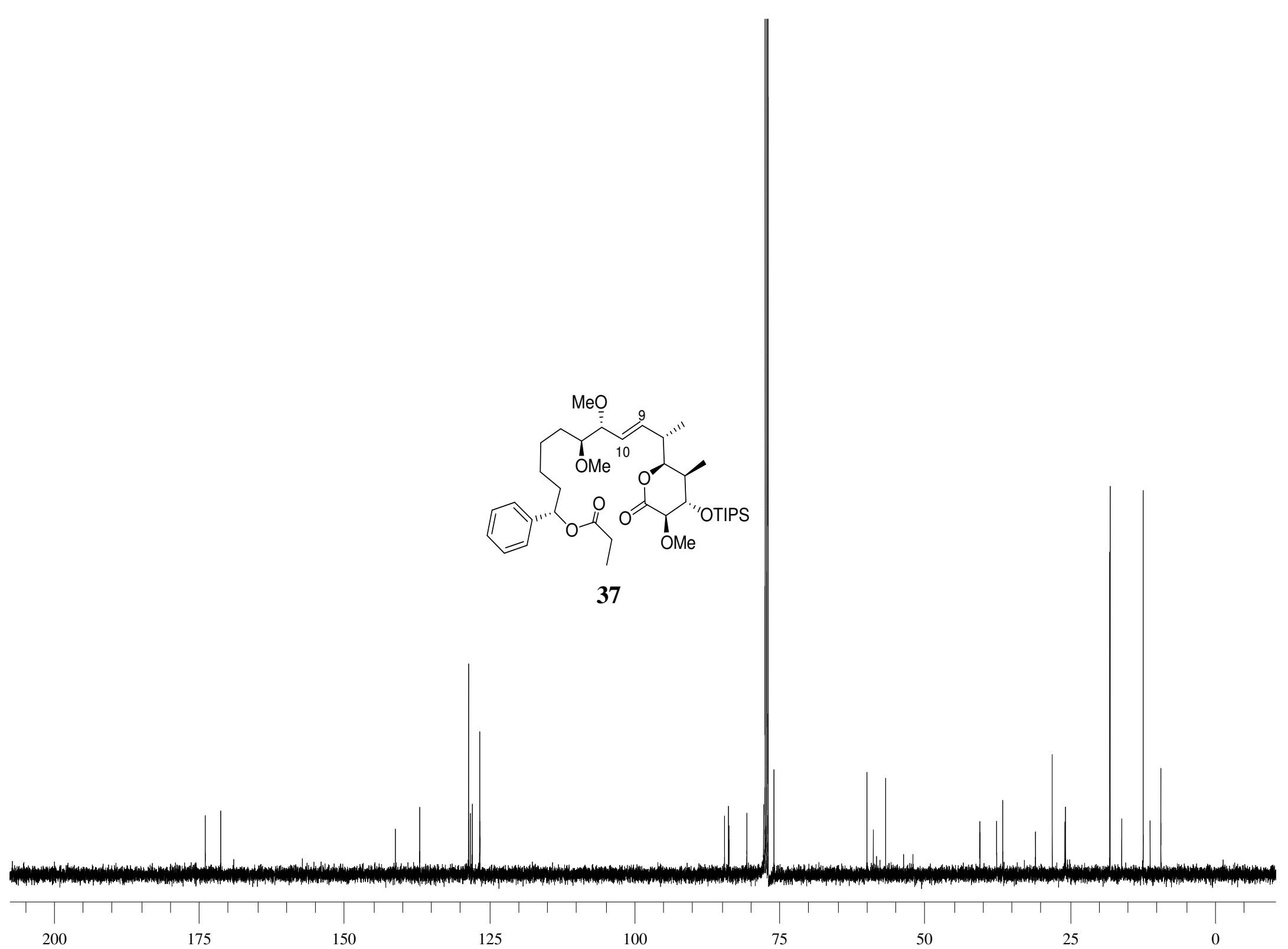




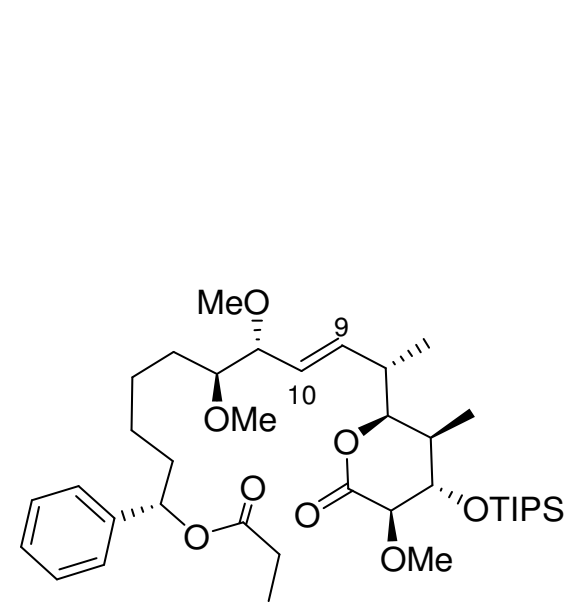

37

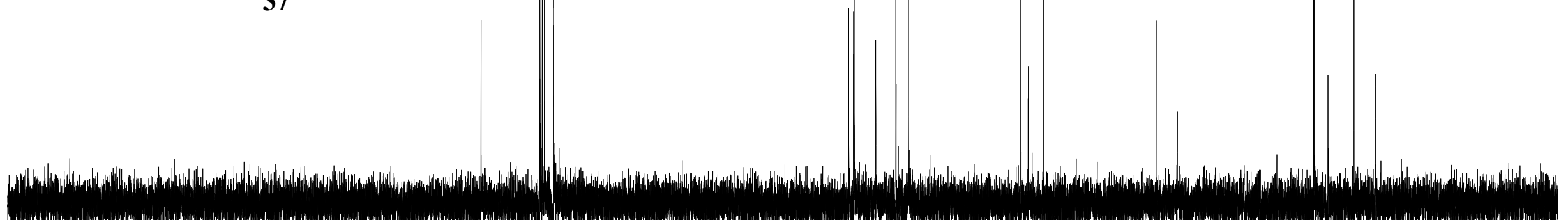

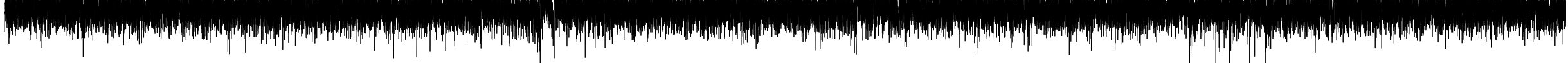

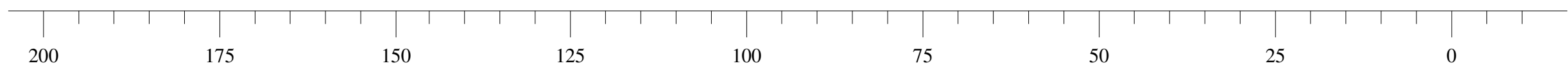


Ciufolini et al.

Studies toward Soraphen A

S 69

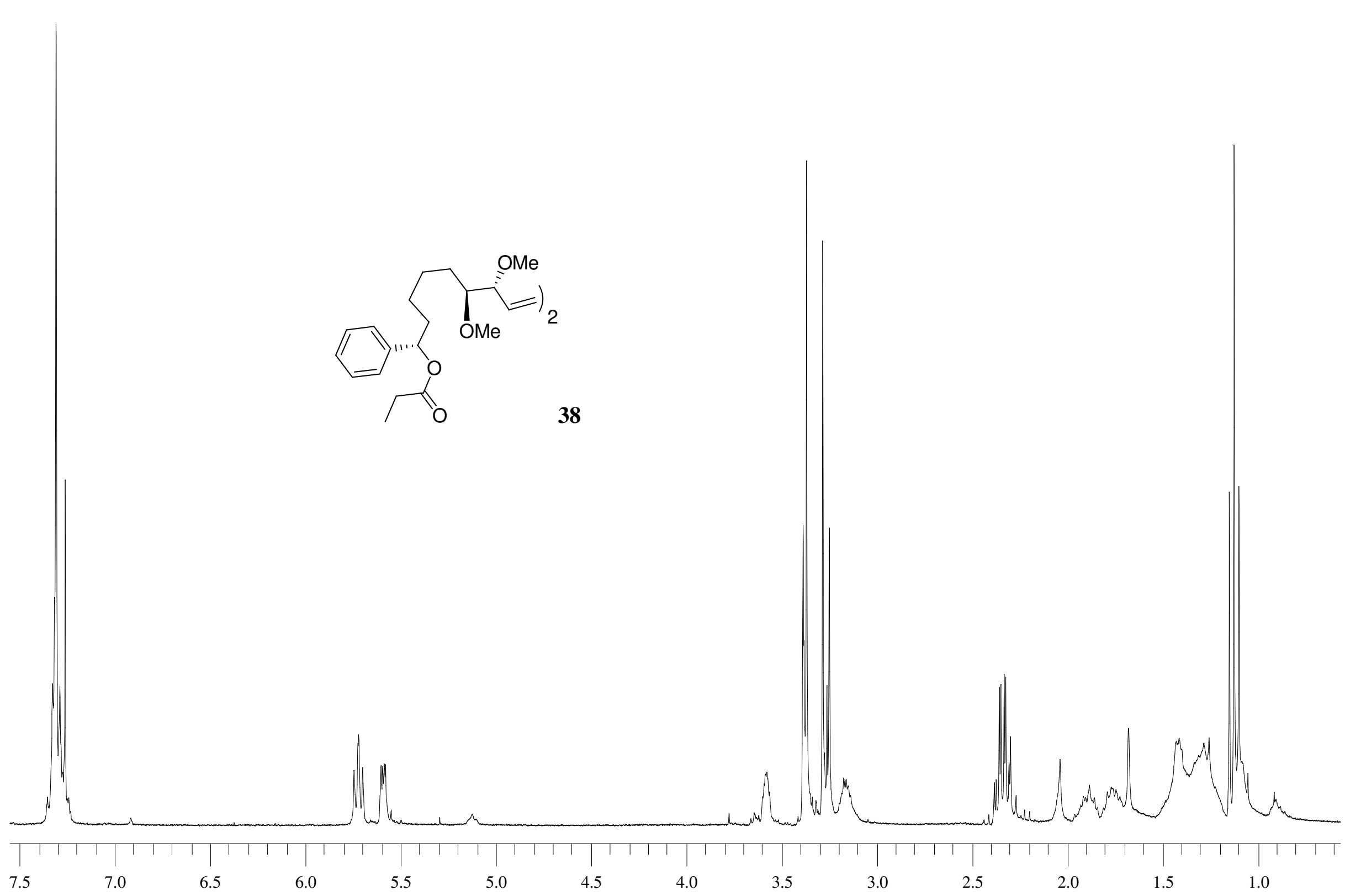




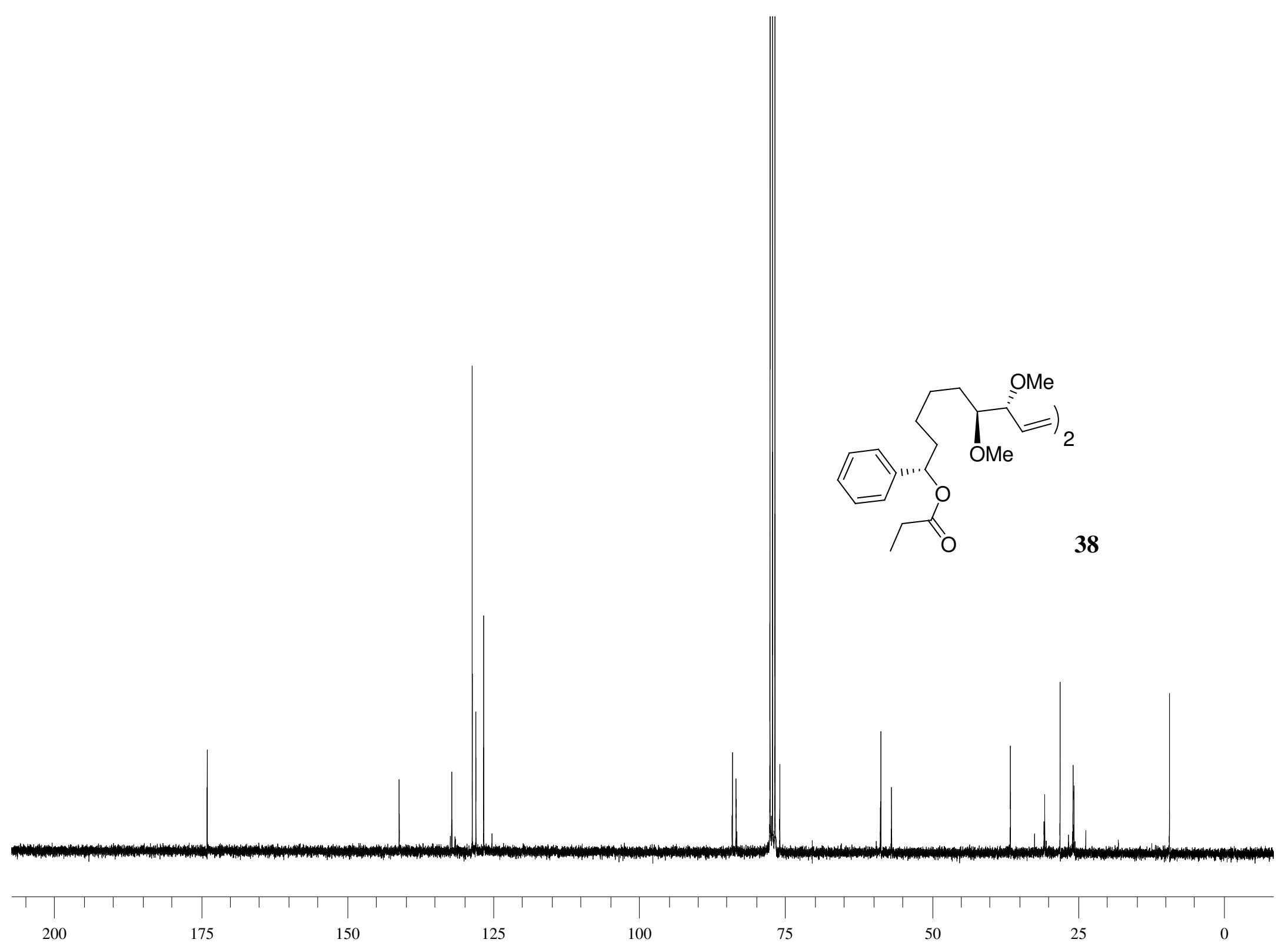




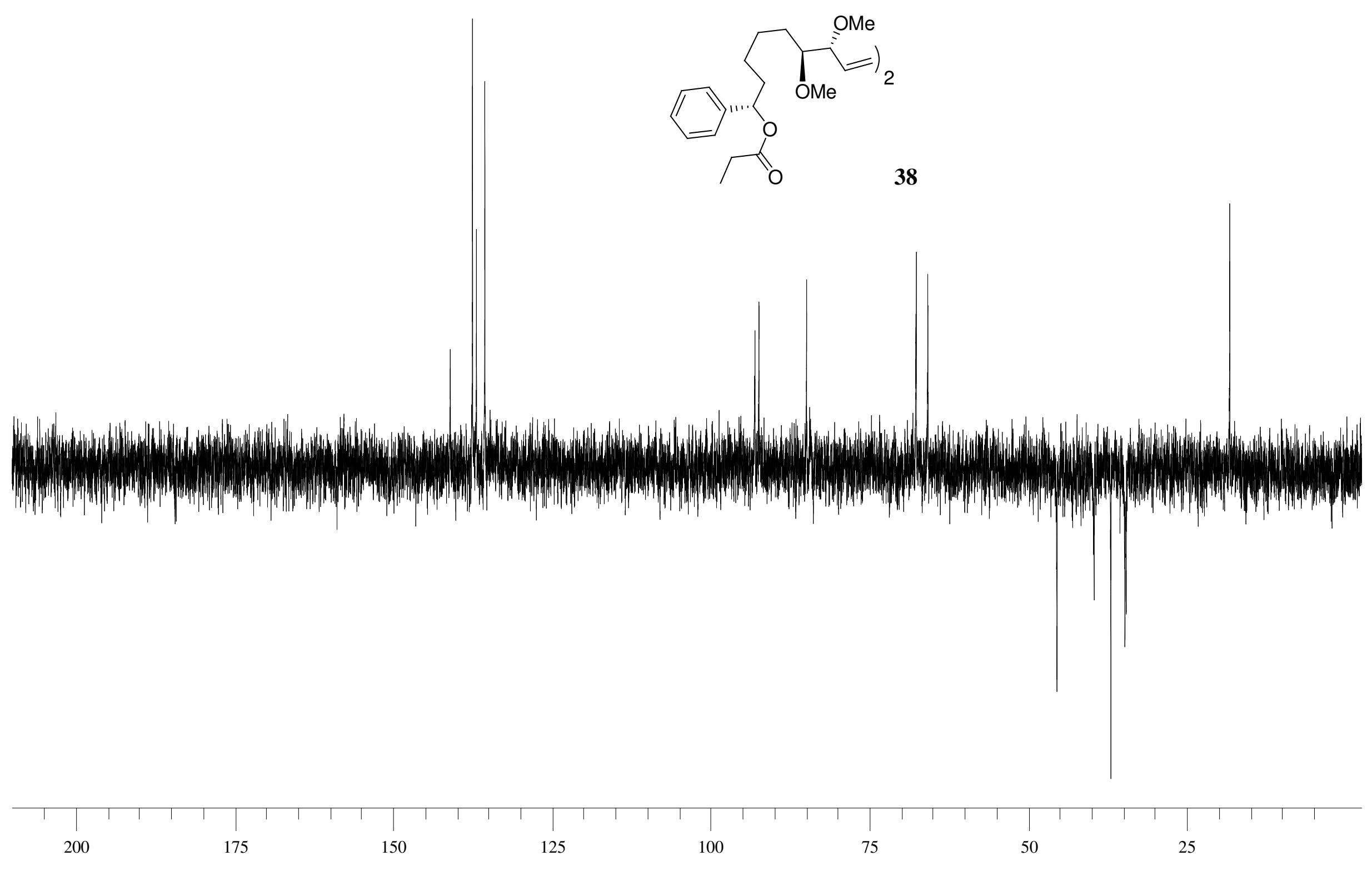




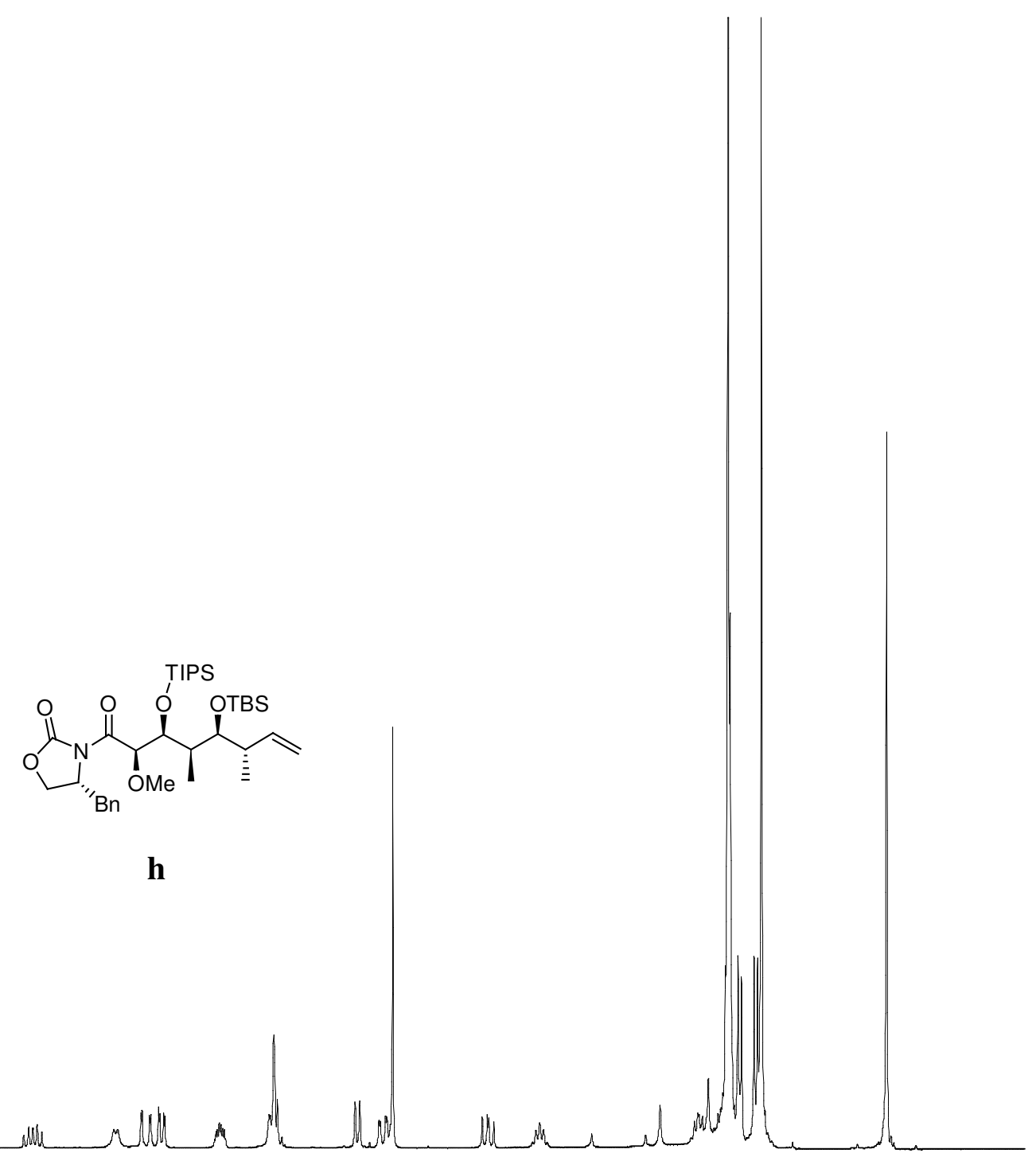

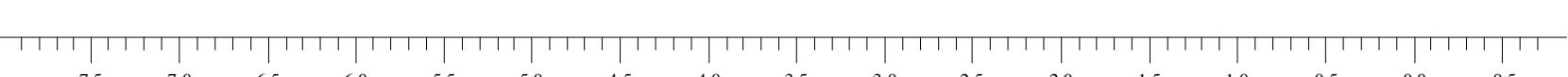




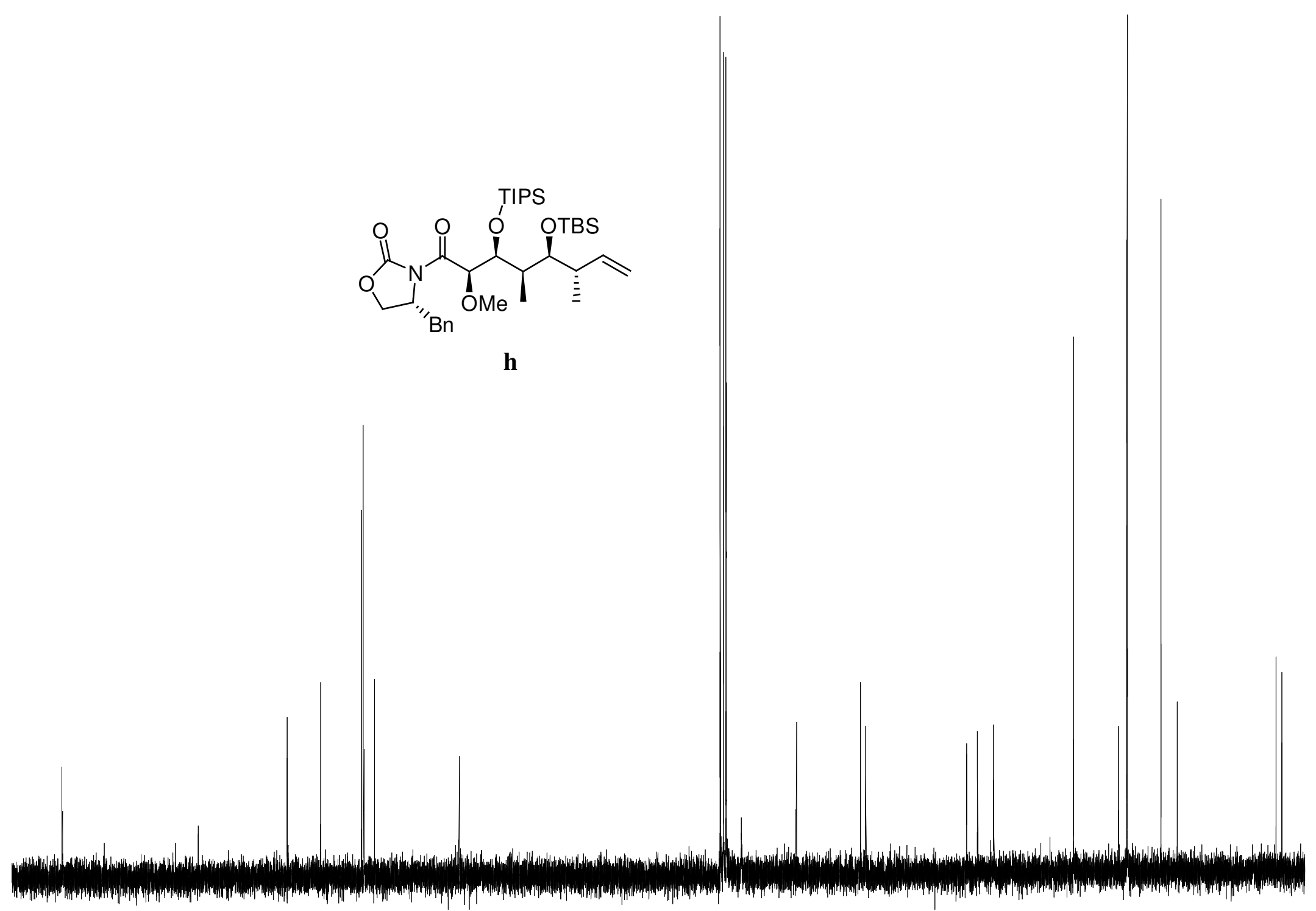

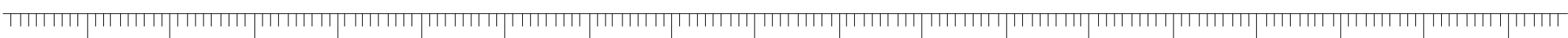




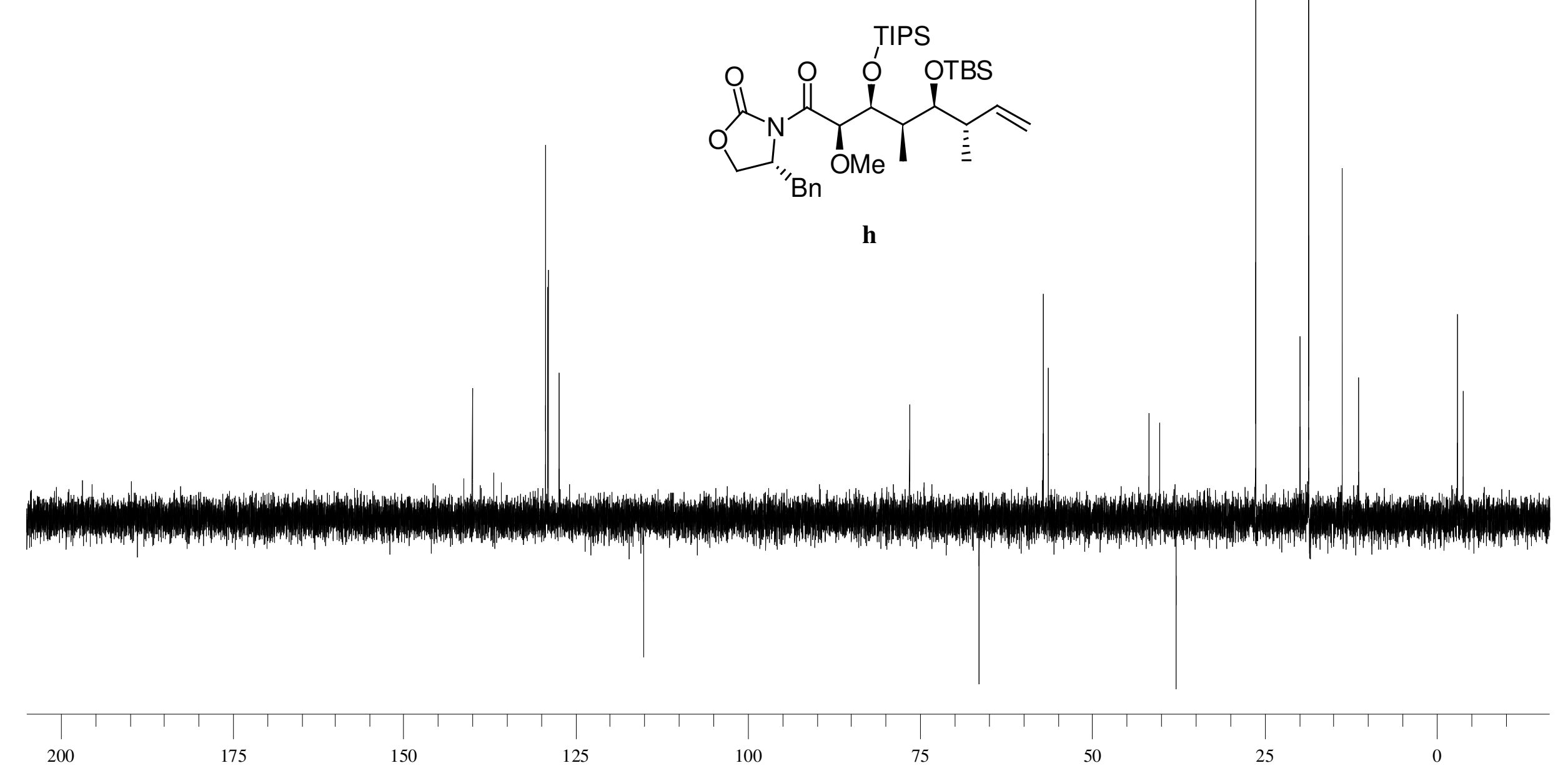




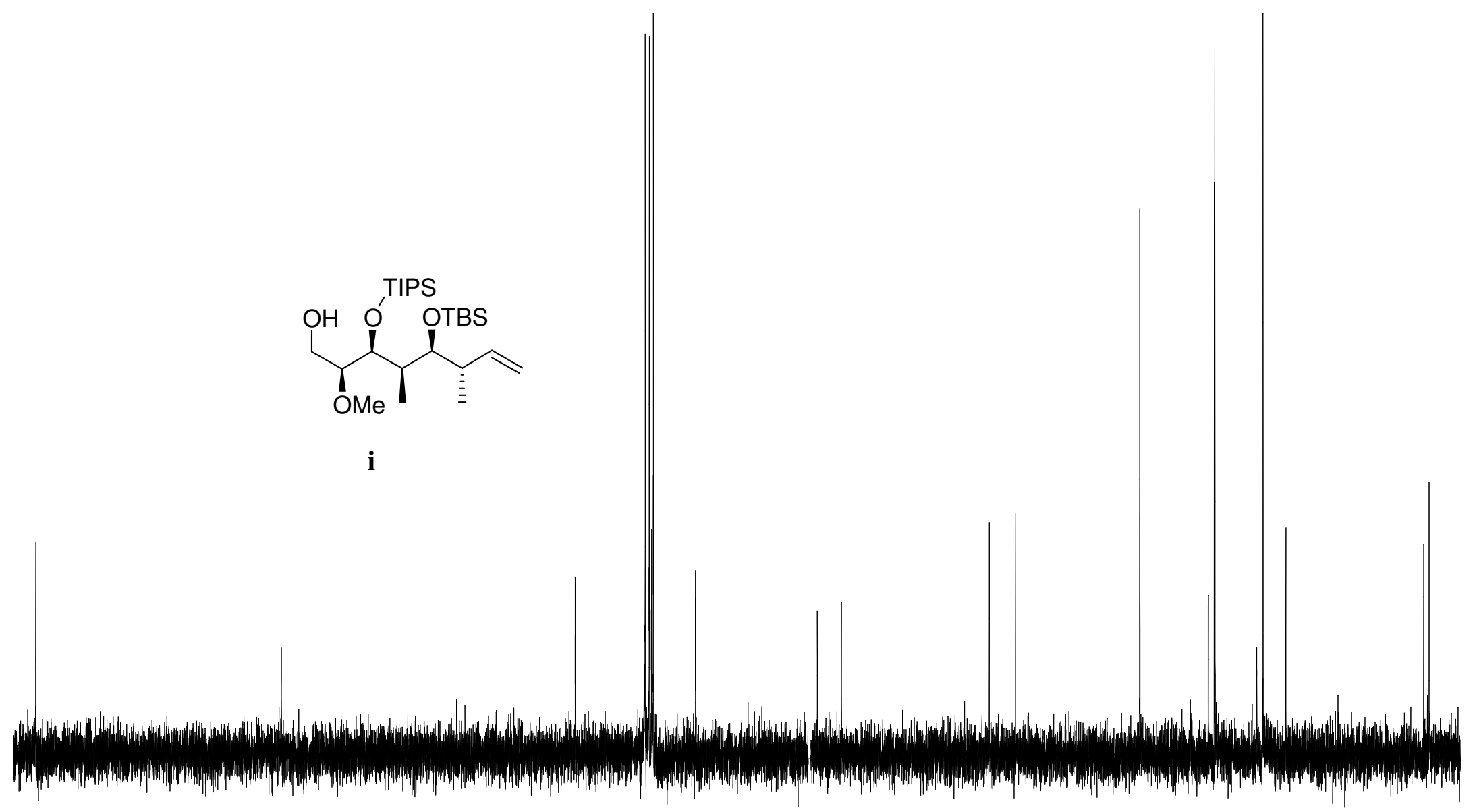




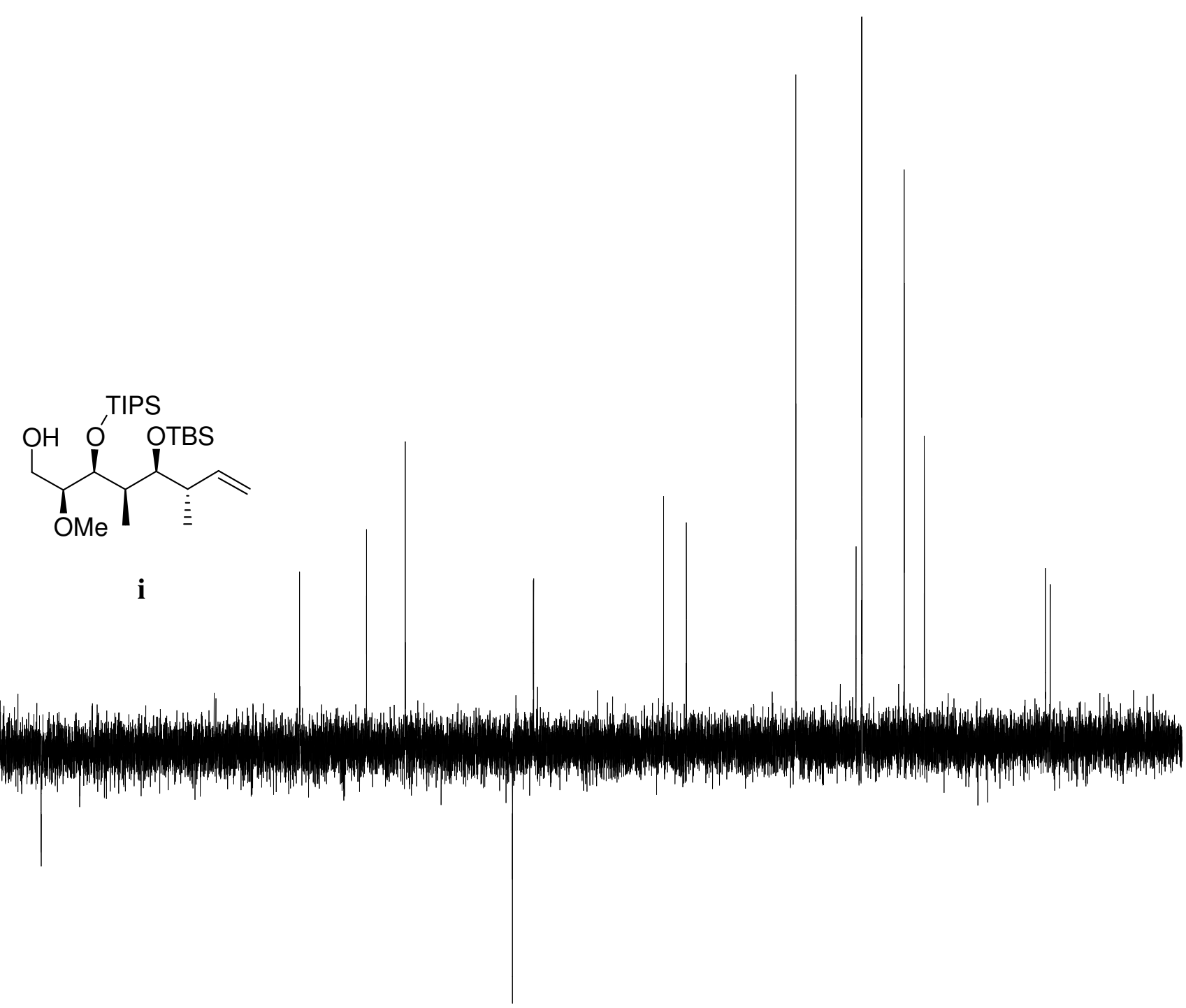




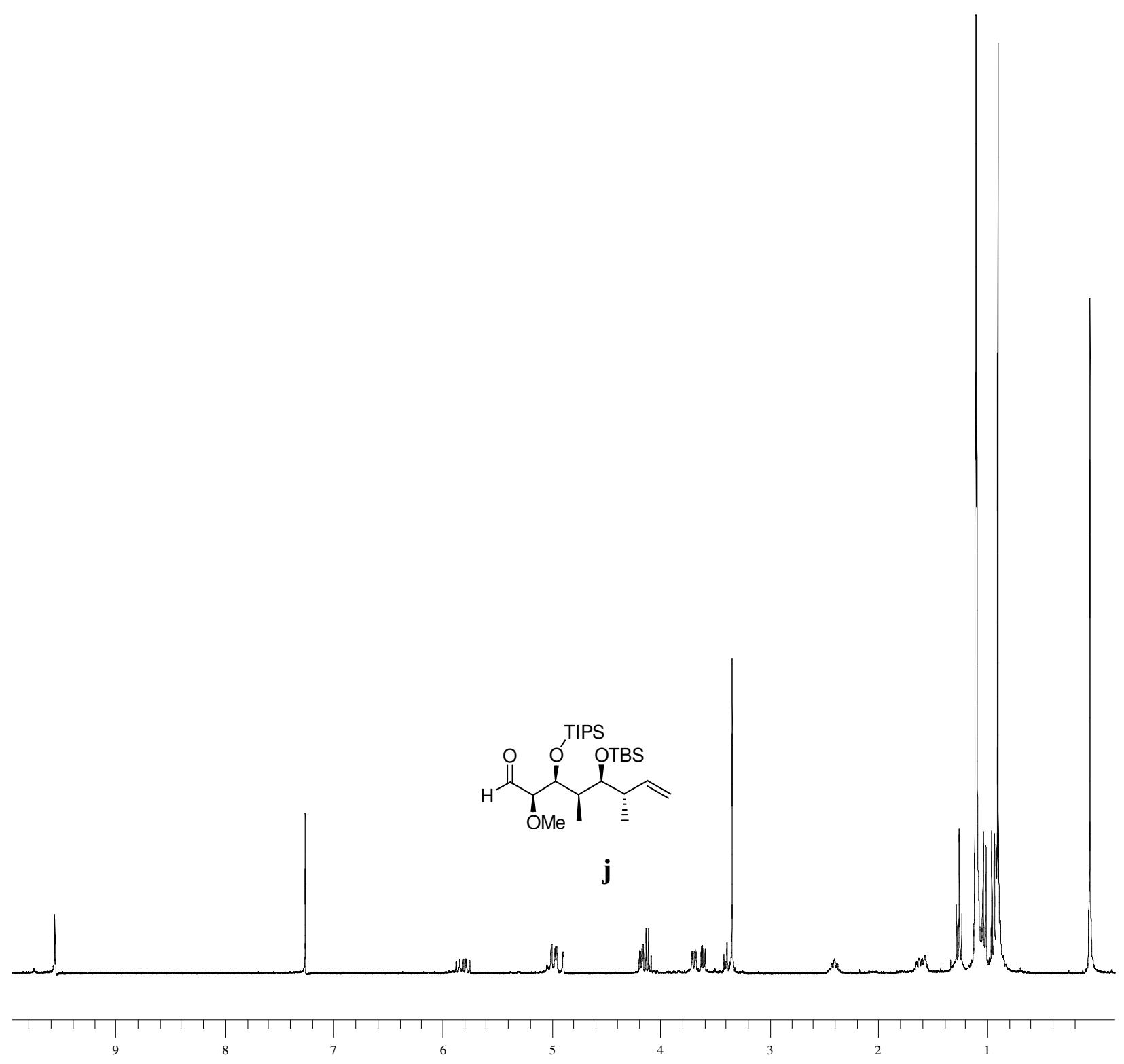




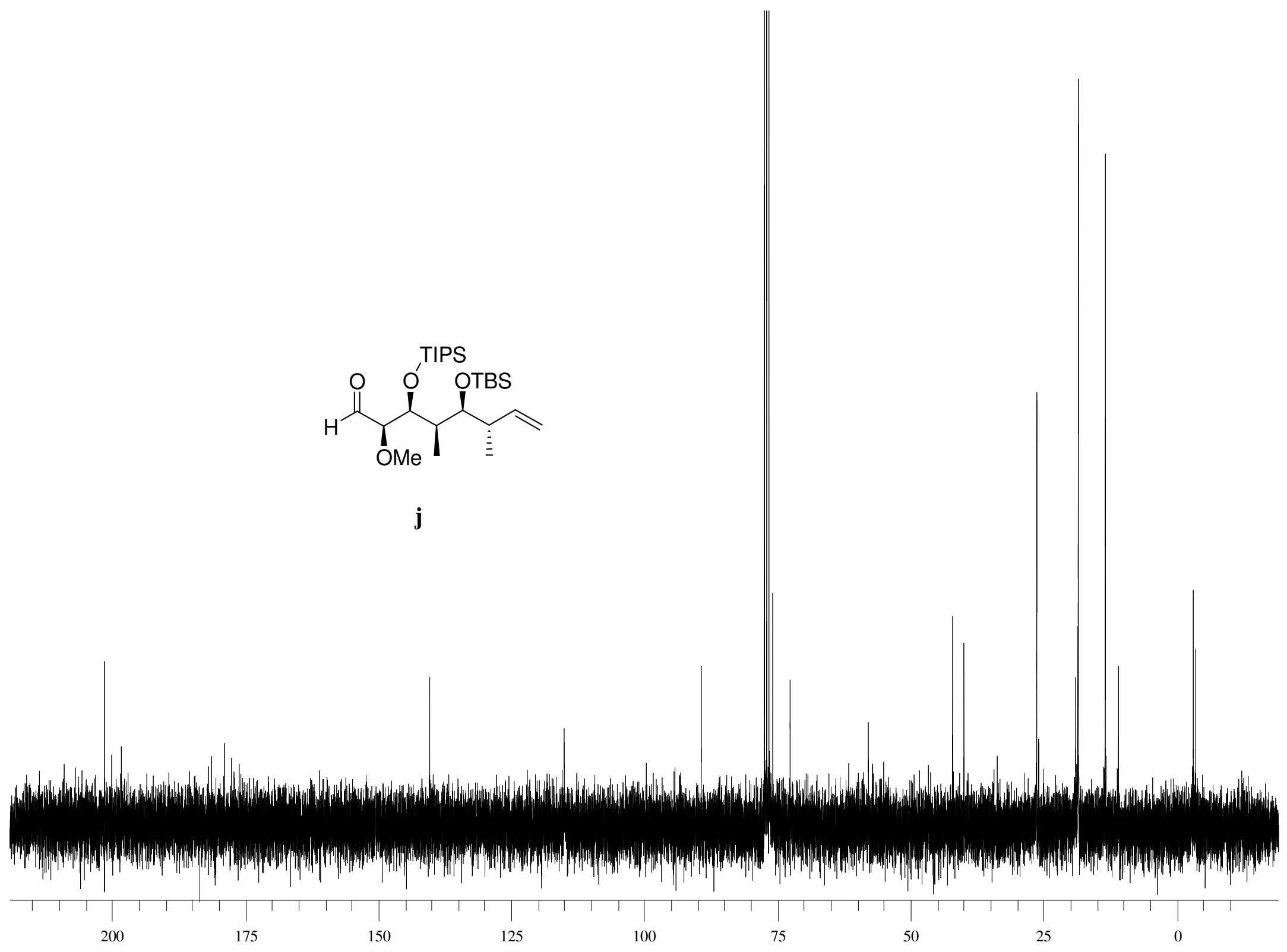



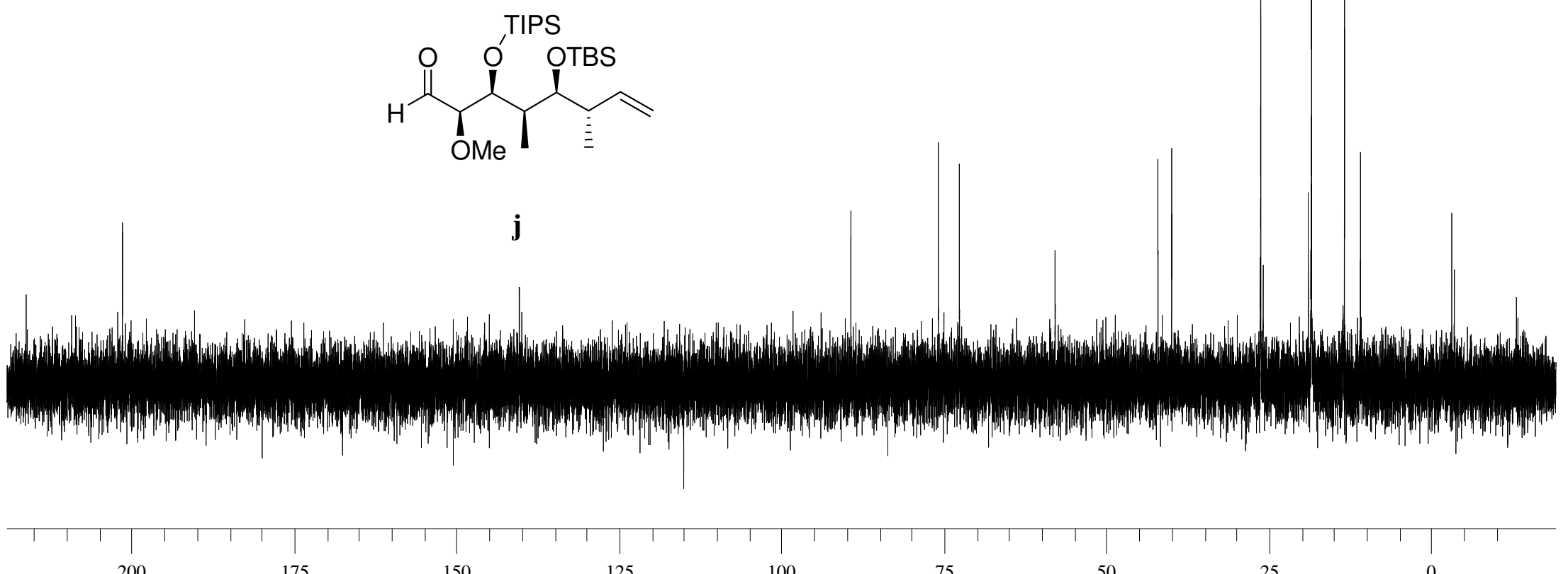

175

150

125

100

75

50 


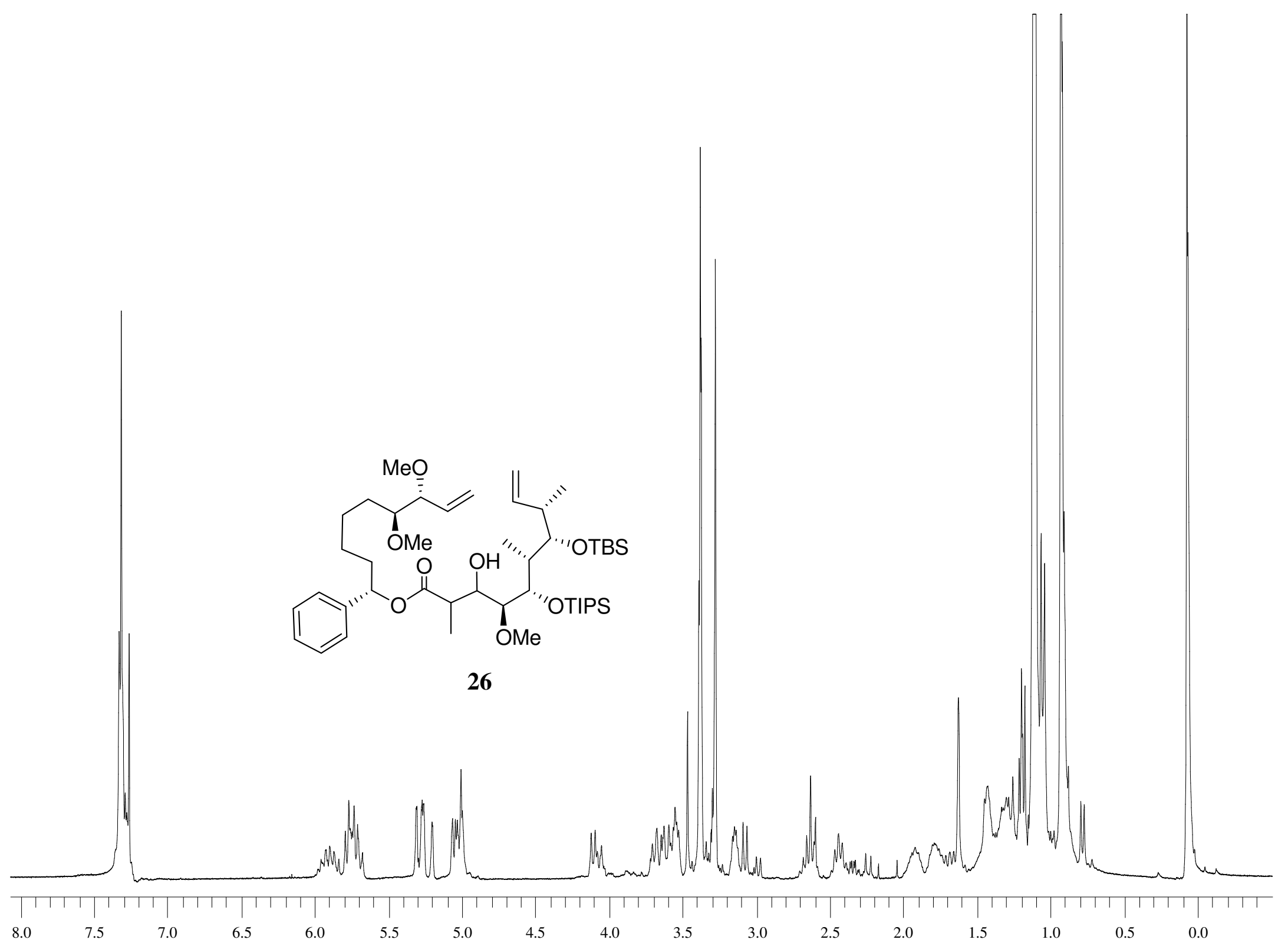




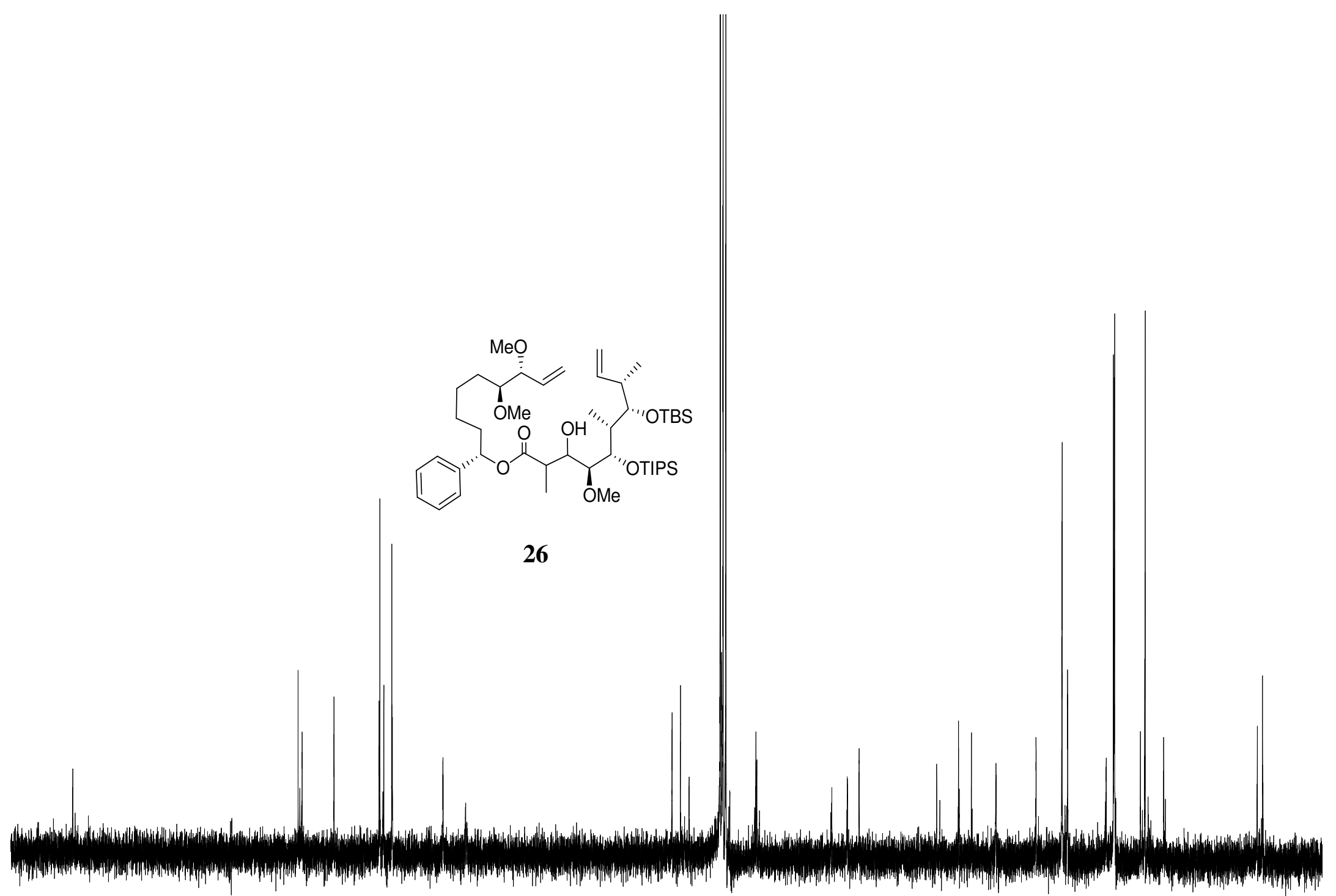

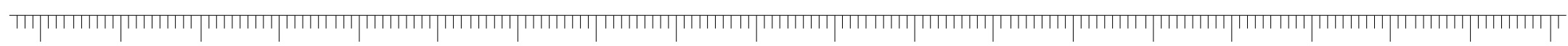




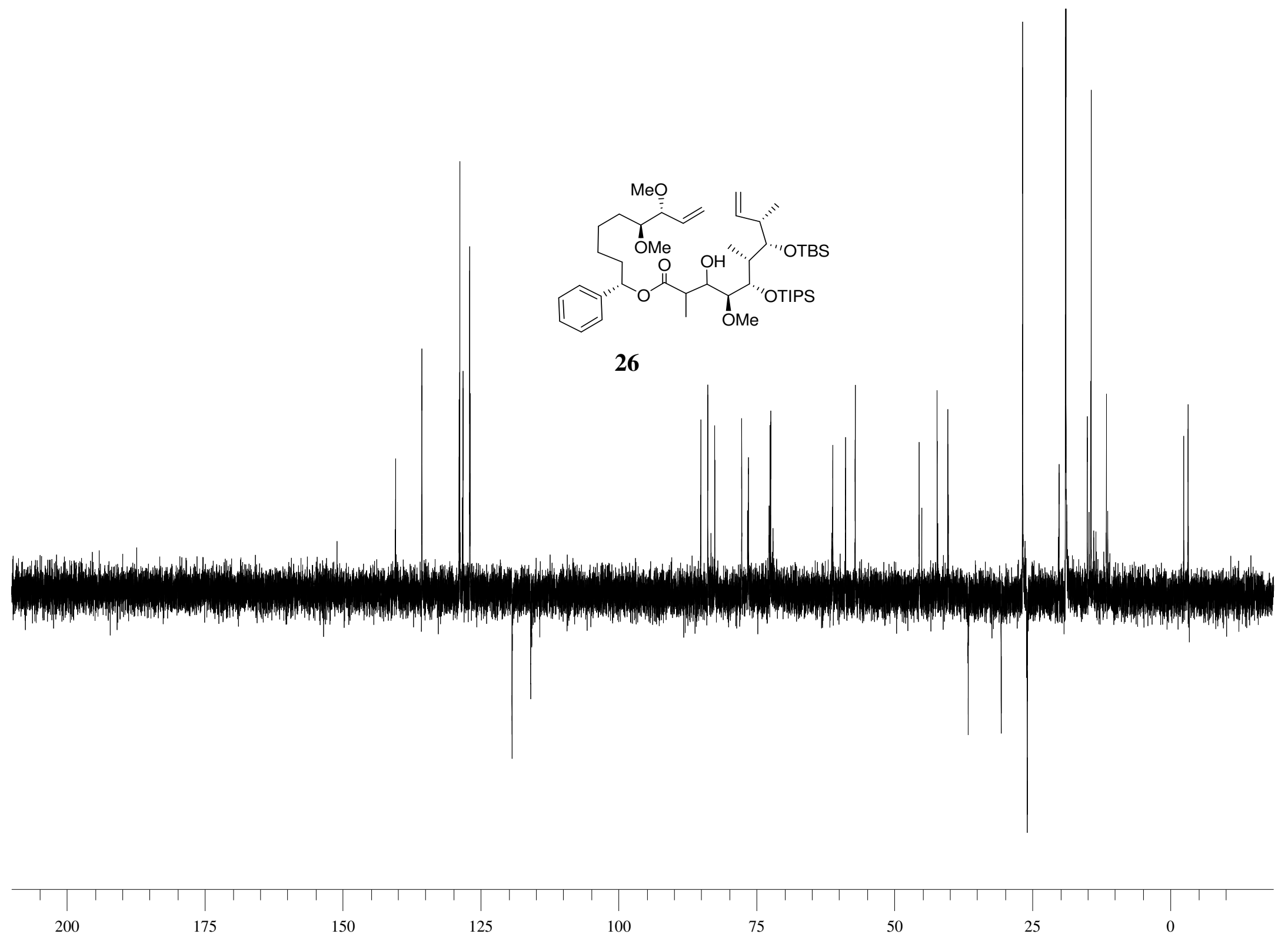




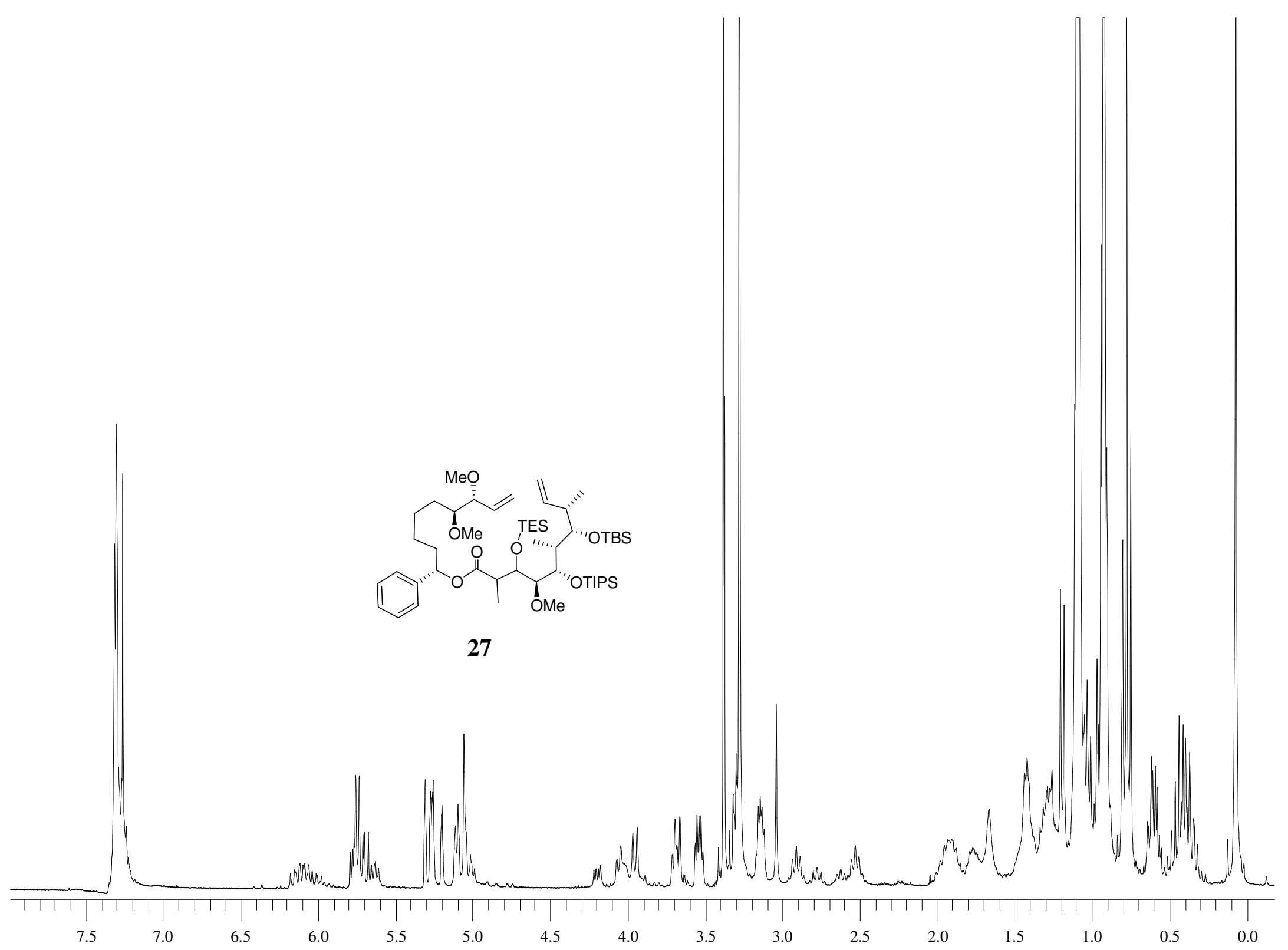




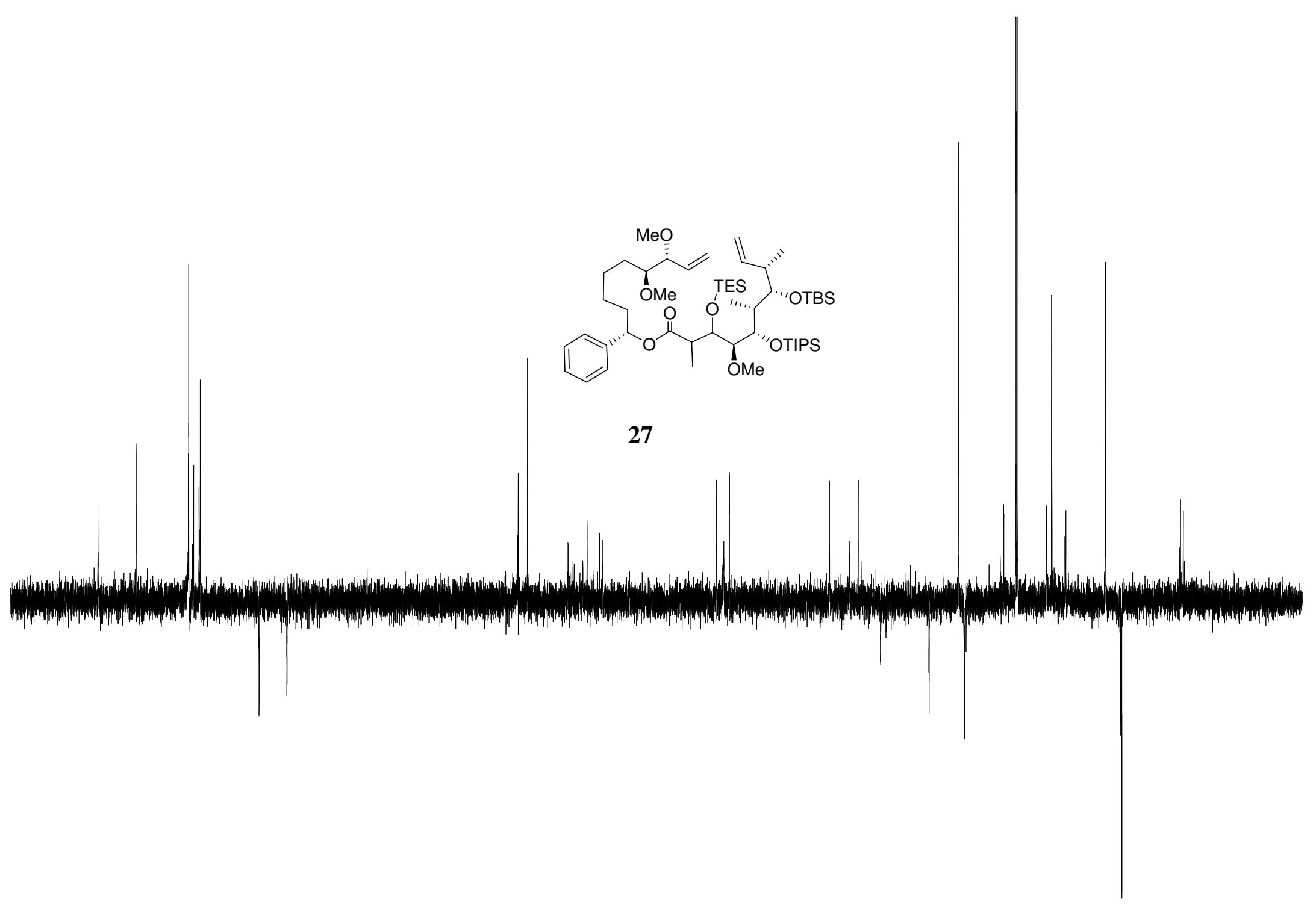




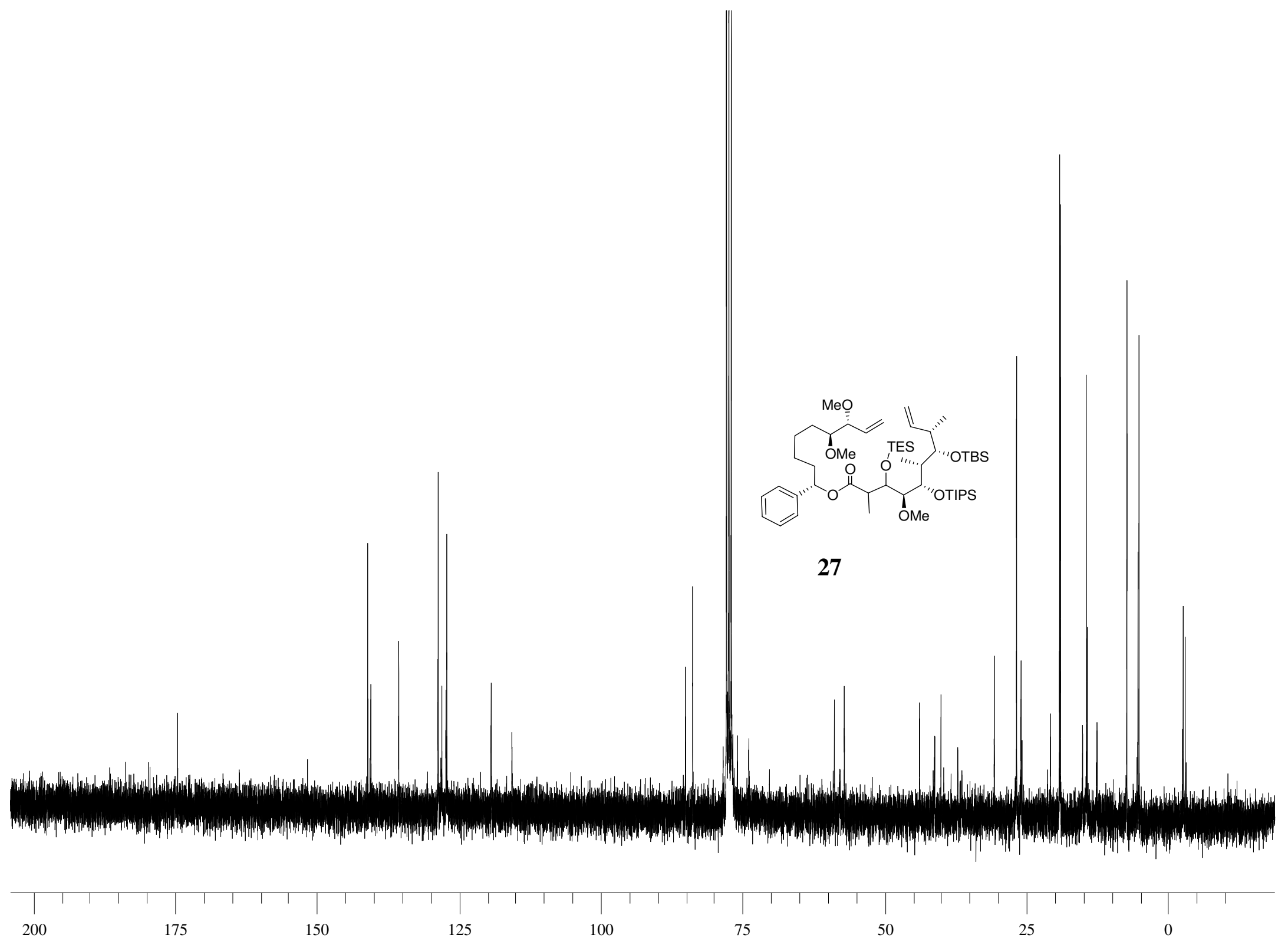


Ciufolini et al.

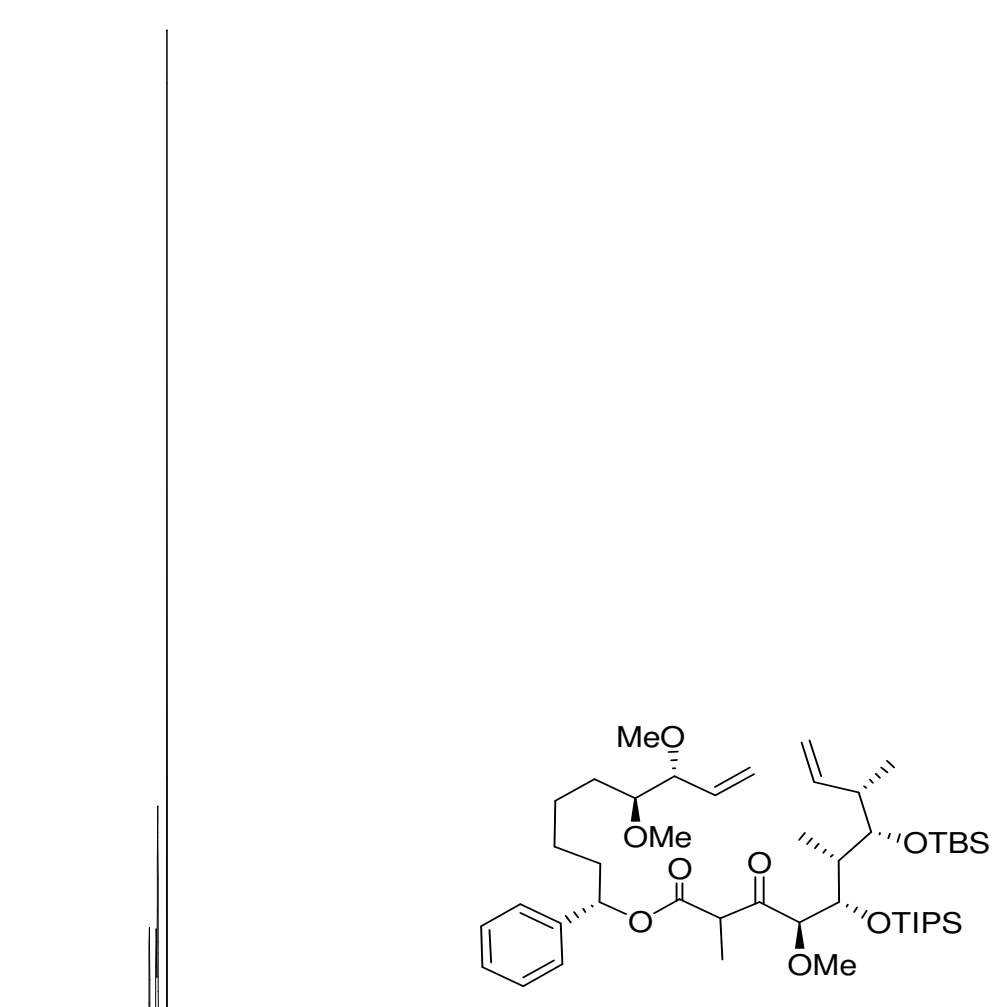

28

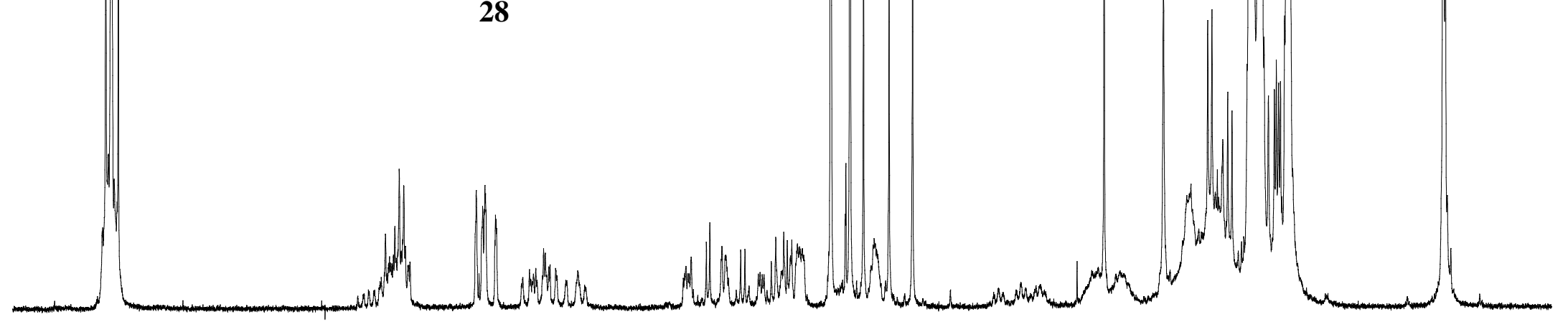

7.5 

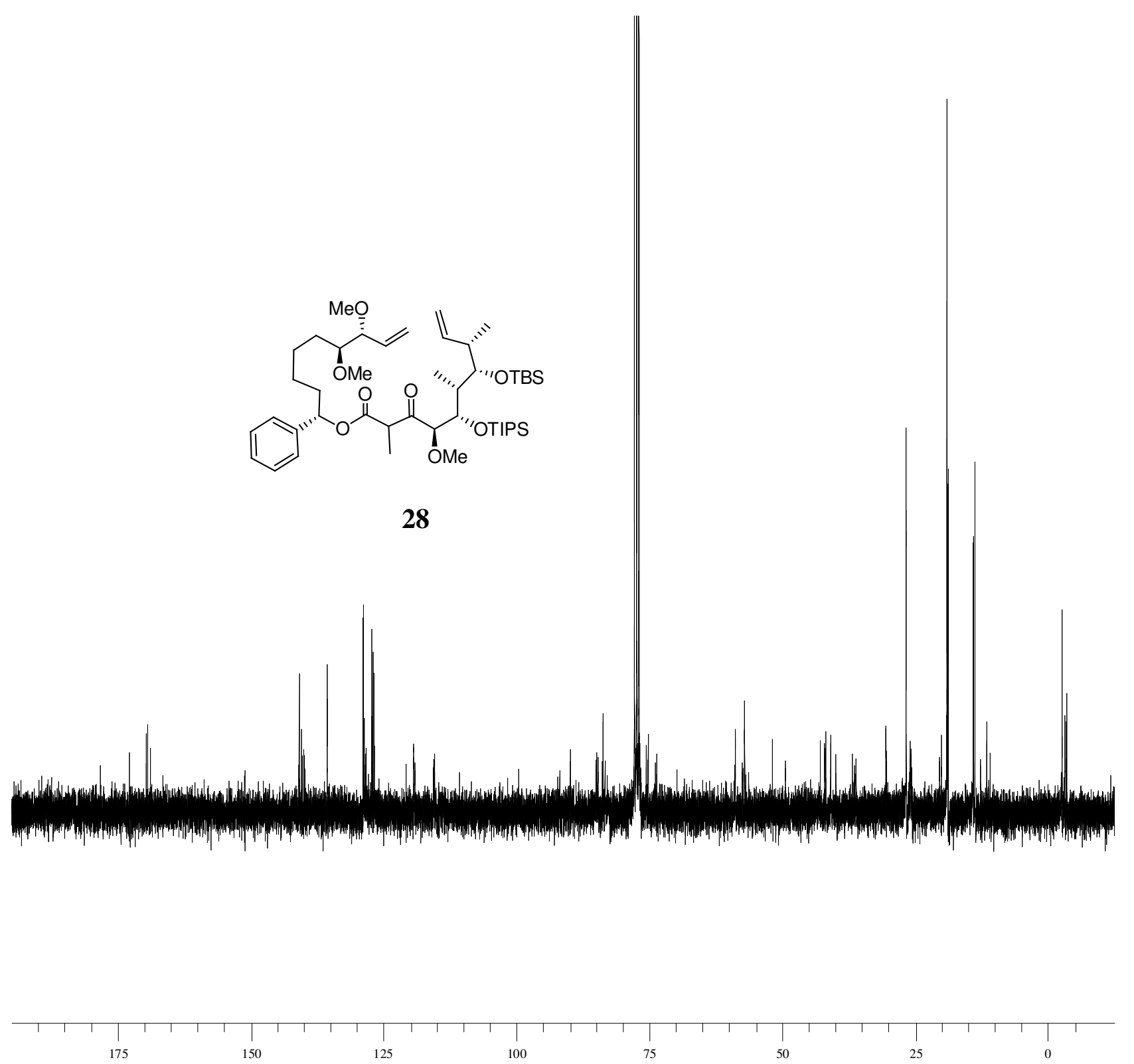

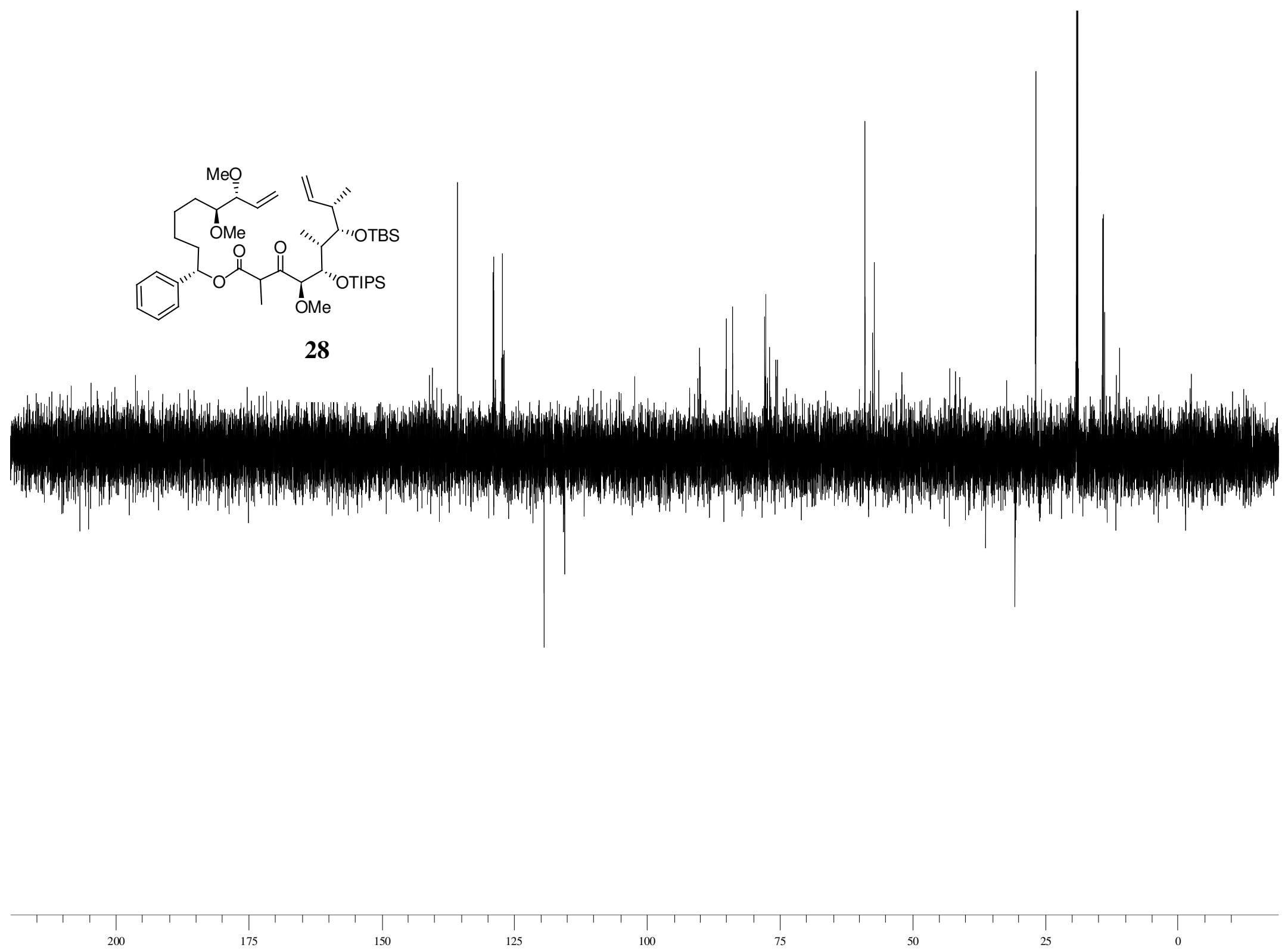